\title{
Bilingual Biblical Etymology - Origin of Language
}

\author{
James Xianxing Du \\ Bilingual Scholar, Cleveland, United States of America \\ E-mail: xx1du@yahoo.com
}

Received: July 27, 2020

Accepted: August 21, 2020

Published: September 20, 2020

doi:10.5296/ijl.v12i5.17716

URL: https://doi.org/10.5296/ijl.v12i5.17716

\begin{abstract}
Multilingual mutual match in biblical etymology is a secret of civilization and definitive evidence for creation, presented for the first time in history. 恐 terror is error to carry ark by two poles 工 to battlefield, 謬 mistake is to take ark marked by cherubim 犸 to shed blood

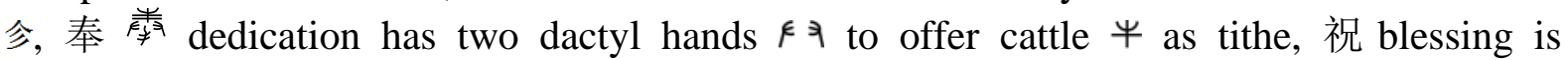
sibling 兄, 嬰 Infant is financial 貝 to fiancé and fiancée, 音 Sound has Son 童, 急 sonic is in

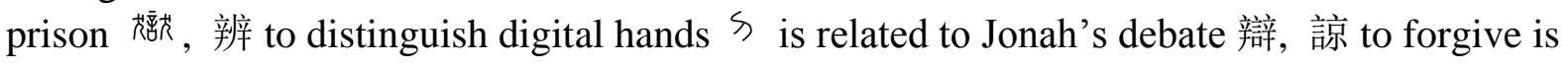
related to whale 鲸 and capital 京, and 黝 criminal label has capital after 殳 killing Abel from 款 grain offering. Biblical books such as Genesis, Exodus, Leviticus and Jonah are astonishingly validated by bilingual mutual match in biblical etymology. Bilingual mutual match links 退 quit to quite 很, 骄 pride to bridge 桥, 宴 banquet to bank 堰, 霉 mould to plum blossom 梅, 園 garden to garment 衣, 悛 repent to paternal 公 Adam, 悔 remorse to maternal 母 Eve, 濁 opacity to optic 目, 稠 dense to seeds 禾 on altar 口, 脯 sausage to use

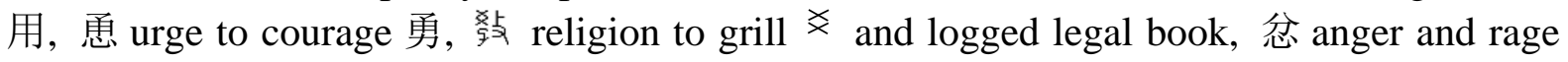
to revenge in segregation 分, and 朝 morning to mourn 悼. Many affixes are presented, such as nat+vowel of native, innate and nation as tone, wh as human near water, 乍 restricted motion in 炸 explosion, migration to circumvent giant 巨, a motion affix 夋, 天 human to flee, 匽 to hide Moses in basket $\odot$ near Nile bank 堰, 兆 water and fire, 埝 co-carriage of ark and altar, 用/角/甫 as altar's service, and 采 as star. Known affixes such as com, tech, 巴, 追，貝 and 曼 curtain also match biblical etymology. 爸 father is to thaw fat 肥 in faith at thermal altar, 疤 scar has sacred worshiper 巴, and relative is related to altar. Creatures have biblical etymology. Clove is created to resemble cloud, tendril resembles spilled blood lines on tent's curtain, 藤 vine has vineyard ${ }^{*}$, vessel 舟, 火 fire and Noah's hands ${ }^{k 2}$, dolphin has phonic ultrasound, and elephant has elevated sound. The systematic bilingual match in biblical etymology spans all categories. Wednesday is water condensation and seed day, 奥/ 謎 mystery has star 米, 樂 music, smile and laugh have semi and halves, 球 sphere/globe is ephod/robe 装's pomegranate, textile has to exit in exile, filament has flame, fiber has fire,
\end{abstract}


desperation is to tear apart dress, inheritance and heritage 繼 are to tear attire and fragment 迦 garment, 裚 blasphemy is to take 执 divided clothes 衣 for military to humiliate Son, satire has attire, mock is blocked sunlight, Corpse is sacred Sarco on cross, 讽 sarcasm is Sarco and crazy 疯 to validate Jesus, oath is to heat theological offering cut with hatchet, family has flame for kin to kindle, meal in flame is alumni, to incite is to incinerate, to instigate is to ignite, to stimulate is meal at flame of altar, health is to heat wheat at altar, tomb is mobility, and town is own tone and own tower, solving the etymology of numerous words. In conclusion, the entire languages of English and China and also words in additional ancient languages must have been divinely created in etymology to predestinedly and mutually match each other, and equally astonishingly, match bible, as the origin of language.

Keywords: Origin of language, Biblical etymology, Bible, Creation, Religion, Bilingual alignment, Multilingual mutual match

\section{Introduction}

Two millenniums after the sacrifice of Jesus Christ and eight years after Mayan prophecy of new era, we face a crucially essential time in human civilization. Basic themes universally believed by ancestors, such as our origin, origin of language, and eternal life, are frequently addressed by revealed scientific knowledge. For instance, fossils indisputably prove Genesis' chronological order of species. Tumors' gradual and broad-spectrum accumulation of all mutations fits the core requirement of the impossible hypothesis of natural selection perfectly well but completely disproves natural selection, because they never give rise to novel functional structure and hence never evolve, except forming mass and eventually destroying their hosts. Molecular biological logic of mutual dependence, lack of transitional forms, and irreducible complexity nullifies any impossible hypothesis of natural origin, which has no any experimental evidence but sequence and inter-species similarity due to identical source of creation (Standing for Truth, 2020).

In consonance, systematic testimonies indicate that ancient languages have bible as their etymology, with multilingual mutual match in biblical etymology, completely validating divine creation of words ( $\mathrm{Du}, 2019 \mathrm{a}-\mathrm{c}$ and 2020a-e), a conclusion statistically definitive by both random sampling of words and concentrated etymological analysis of specific categories. From Genesis to flood, from numbers to heavenly stem and earthly branch calendars, from Eden to Red sea, from Abraham's cut to two to Jesus' baptism, from Moses' miracles to Leviticus' decrees, from prophet and priest to tabernacle and altar, and from organs and body parts to all relatives, words extensively and systematically match biblical etymology with bilingual mutual match throughout dictionaries.

The bilingual mutual match in biblical etymology is so definitive and extensive that even all the words related to health, a major focus of 2020, have multilingual biblical etymology to match Leviticus (Du, 2020c). This article further presents the biblical etymology of many words such as terror, mystery, challenge, mould, 黥, 匽, 饉 starvation, tomb, mock, sarcasm, distinguish, clove, sepal, mute, town, textile, filament, fiber, blasphemy, heritage, shape, globe and sphere, oath and pledge, sound, prison, elephant and dolphin, smile and music, and affixes 乍, 巨, 天, 兆, 质, 后, 夋, 慧 and 曼, definitively proving that words in the 
languages of English and China were divinely created to mutually match each other in biblical etymology.

\section{Method}

Semantic and graphic organization is analyzed for each word to see how its components form a meaningful word to match biblical event, decree or worshiper. For any word in English with identified biblical match, its translation in bone, bronze, seal, traditional and simplified versions of language of China is mutually compared with it to verify the identical etymology or search for related etymology, and vice versa. Word linkage analysis is also performed to interconnect words of biblical etymology.

\section{Result}

\subsection{Multilingual Biblical Etymology of Health}

In etymology, health is heat and wheat at altar. Since human's letter $\mathrm{h}$ is er, 康 health is also leather, and its bone version 曾, bronze version 兼 and seal version 䊝 have peeled cattle or wheat offering 范莱. It has affiliating servant 隶节录, hand holding offering. Wheat has heat of health, and health heals at altar (Moses, 2nd millennium B.C.c). In 2 Chronicles 3:1, the shrine built by Solomon "was on the threshing floor of Araunah". Threshing chaff and husk 糠 of wheat, Araunah was generous 慷, “Take it!”

Consistent with numerous words of disease and treatment in multilingual biblical etymology

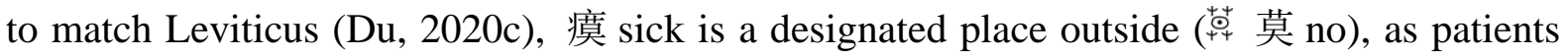
could not reside inside camp and must be isolated outside. 疼䣯 tuberculosis has burnt offering with fire 火 near tabernacle. 㾟 measles has meal sema (semi), to slice in halves 八. 癜 skin patches have temple or palace 殿, as the healed should show them to priests, and GOD told Moses $\gamma$ to show the sign of leprous hand (又, マ) in cloak at Pharaoh's palace. In Exodus 3:18-4:9, "you and the elders are to go to the king of Egypt and say to him". "Moses put his hand into his cloak, and when he took it out, it was leprous, like snow". In Leviticus 13:1-14:57, "Priest who pronounces him clean shall present both the one to be cleansed and his offerings before THE LORD at the entrance to the Tent of Meeting." "In this way the priest will make atonement before THE LORD on behalf of the one to be cleansed. These are the regulations for anyone who has an infectious disease". This interprets why canker kindles fire. Related to scintillation, clinic is to burn (cin) offering (il). 疥眿 scabies has cut (sca) to two (bi) 几. 瘡 sore has storage place 倉倉 with tent A. 揤 skin inflammation has

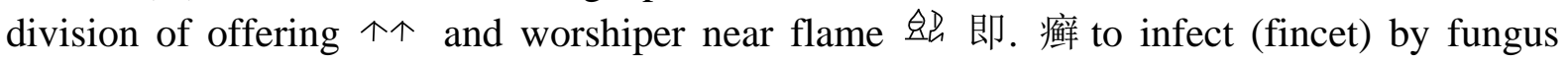
has fingers $\zeta$ at altar with fire 恩 and sheep/goat 羊. 疔 boil has lipo and firelight $\uparrow$ as fat must be burnt at altar. 瘫 inflammation with fester has worshiper 巴, altar 口, 《 flame and bird 隹 as burnt offering. 疸 jaundice has to dice offering near burnt altar 日. 疝 hernia has fire $\leadsto$ to burn. 痢 diarrhea has hand to offer wheat 乐, and dysentery, dys entery, is dysfunctional intestine. 疳 digestive disorder has altar $\exists$ with horns ${ }^{A} \exists$, copper grating and ledge. 疴 severe disease has altar $\square$ to serve.

疫 scar has ark (arc) 舟 and worshiper's hand 㔯 传 sacrifice. 痕 mark has offered ram and ark. 疤 scar has sacred worshiper $?$, no matter such a scar is from circumcision or not. 㾉 
barren has raven for barren land or bird offering 北. 瘦 lean has aged senior in worship 叟, but is also thinner offering without fat, as all fat must be removed. Lean has no animal oil. In Leviticus 3:16-4:19, “He shall remove all the fat from it and burn it on the altar". 肥 obese has worshiper $?$ who observes offering $\stackrel{\oplus}{?}$, as the fattest is offered, although the leanest meat was eaten. In Genesis 4:4 "But Abel brought fat portions from some of the firstborn of his flock. THE LORD looked with favor on Abel and his offering”. 爸 father has fat to burn at thermal altar by earthly father of faith, Abraham, and faith has fat to heat. 疿 injury has either archer 夷 or bowing worshiper. 疦 damage by bleeding has hand ₹ to offer offering ?

病 wart is ram at altar to atone hard growth on skin. 診 prognosis is diagnosis of agony 疼. Prescription is from scripture to confine infection. 疮瘩 is lump of abnormal growth, and has to beg 乞 to answer 答 reconciliation 合. Not (不) at altar (口) is 㾙 lump in abdomen. 疪 is shrunken swelling before offering gift at shrine by worshiper $ヒ$. 痦 mole has me 吾 and altar 口. 志 determination is to deter mine. 痣 mole has limited movement $\underline{\Psi}$ to deter entry into Tent of Meeting, as in Exodus 12:5 and Leviticus 3:1-22:20, "he is to offer a male or female without defect" and "because of his defect, he must not go near the curtain or approach the altar, and so desecrate MY sanctuary." However, physical sanctuary needs to be rebuilt, but Jesus has renewed the law by building spiritual temple for everyone to enter.

癱 paralysis has ox 廿 and bird 隹 at fire. 疾 paralysis has 覆, worshiper $\boldsymbol{p}$ to divide 八 in front of Tent of Meeting $\cap$ with parallel hands $k$. Paralysis is cut (lysis) in pair (para). 痹 paralysis has burnt offering near altar 田. 痂 scar has limb/arm 力 and altar 口. 㾉 lame/limp has limb/arm 力, meat 肉 and altar 口. Such words could not have been invented by human, because to add mouth meat (加口肉) could not be limp according to previous traditional interpretation. Limp would not add flesh to mouth, but Hebrews pray for healing by adding more flesh to burnt altar.

In old testament, GOD brought diseases - though not cancers - to discipline people, although at new testament law of love has been established through Son of GOD, and GOD does not directly bring in disorders until approaching the end of time as prophesied (Matthew, Mark, Luke, 1st century, John, 1st century b). Even cronovirus was not new species: it was present but could not be detected, because we did not know its genetic sequence and coat structure, so that detection kits were not available.

Cancers are immortalized cells that proliferate forever in culture. This hints that immortalized life could have been created, but GOD opted not to directly offer, in order to test mankind for selection in final judgement. 癌 cancer reflects patient's character 品 to char offering at altars at all regions. Derived from Greek and Latin, cancer of oncology is onco (anco), conon, fire $\checkmark$, although this is also because cancer meant crab or a constellation, and crab resembles rabbi to char offering and raise both arms to pray and worship. In 1 Corinthians 13:4, "Love is patient, love is kind." Pretty much all cancers are murders. Dr. Marie Curie invented the term and theory of radioactivity, isolated isotopes, and discovered polonium and radium. She contacted billion, trillion, zillion higher dosage of radiation, but still lived to a senior age and won Nobel prize twice, an award only to live people, as cancer is an effect of targeted radiation. Cellular and immune mechanisms answer why it is normally impossible to get 
cancer: mitochondria automatically eliminate significantly mutated cells by inducing apoptosis, programmed cell death, which is also one reason why endosymbiosis can not be true for the origin of mitochondrion-Host cell initially intakes a death inducer! Immune system eliminates any novel antigen that is not your original own, to guarantee that you are exactly yourself, not any newer species. This is why organ transplant is difficult and all organs have biblical etymology (Du, 2020c).

The vast numbers of ancient medicines contain either specific treatment or sophisticated components in precise dosages and ratio, with detailed information on symptoms and prohibition for pregnancy and children. A lot of these components are rare or difficult to access. The treated disorders could be very uncommon. Injured Fracture Setting pill consists of twelve components: Carthamus tinctorius L., Steleophaga Plancyi, HgS, Semen Strychni Pulveratum, roasted Commiphora myrrha, Panax pseudo-ginseng, Asteroidea, roasted chicken bone, borneol, roasted natural copper compounds, roasted Boswellia carterii Birdw resin, and Semen melo. It is extremely difficult to develop such drugs, and clinical trials involve time, resources, people and labor. How on earth these ancient medicines could be known? GOD is logical answer. These herbs are apparently effective, such as the detailed procedure to Artemisia annua L. compiled in 《Prescriptions for Emergent Reference》 by Dr. Hong $\mathrm{Ge}$ (Ge, 4th century), the source for Nobel laureate Dr. Youyou Tu's breakthrough of malaria drugs artemisinin and dihydroartemisinin (青蒿素, C15H22O5). 疮/痎 malaria has $\operatorname{arm} \subset €$ of worshiper 人 to offer in front of tabernacle. 警 alarm has 敬 piety of word 离, and 瘴 malaria has 章 regulation with altar $\Theta$, although mal air was its traditional interpretation.

\subsection{Etymology of Terror, Horror, Torture and Error}

虐 torture is terror to arrest 虏, as $巨$ is $\nearrow$ arm that represents force 力 (Xu, 100-121 A.D.). Torture has terror, arrest has terrar of terror, and to interrogate has tortre of torture and terror. 俘 arrest is man (ar) at rest, and has hand $\pi$ to arrest Son of Man or son (子) of man (人), as Samson was arrested after rest. 虐 torture is to this biblical judge of great force in Judges 15:18-16:30. 恐 珒 terror has this hairy worshiper 寻 to work 工 in prison, whose grown hair recovered his vigor. 工 work is effort to fortify 巩 and has ark. 筑 architecture is to build ark (arch) 工 and altar.

In additional etymology, terror is error of ark or altar. Horror is error of ark. 恐 珒 terror has Israelite or Philistine 2 to carry ark by two poles 工, $₹$ offering, and the affix of emotion 心. In 1 Samuel 4:1-6:21, although ark should be in tabernacle, Israelites mistakenly took ark to battlefield, and "were defeated". The ark was seized by Philistines. Priests Eli, Hophni and Phinehas, as well as Phinehas' wife, all died. However, because Philistines plundered the ark, THE LORD'S HAND was also heavy on Philistines of Ashdod and its vicinity. "HE brought devastation on them and afflicted them". Piles or haemorrhoids, 痔, has the affix of sickness 广 and temple 寺, as Philistines “carried the ark into Dagon's temple and set it beside Dagon. When the people of Ashdod rose early the next day, there was Dagon, fallen on his face on the ground before the ark of THE LORD". It has to be mentioned that piles 痔 should not be translated as tumors, as the terms cancer and tumor are absent 
throughout bible. Human dismembers, gouges out eyes and cut off fingers in Judges 1:7 and 16:21, and murders by cancers, but GOD never does these cruel tortures as recorded in bible. Thus, CREATOR is much more merciful than the creature, although in theory GOD can do anything wanted and wiped out dinosaurs, the symbolic dragon.

After they moved the ark, "THE LORD'S HAND was against that city, throwing it into a great panic. HE afflicted the people of the city, both young and old, with an outbreak" and "death had filled the city with panic; GOD'S HAND was very heavy on it" with pandemic. Philistines asked, "What shall we do with the ark of THE LORD? Tell us how we should send it back to its place." They answered, "if you return the ark of THE GOD of Israel, do not send it away empty, but by all means send a guilt offering to HIM. Then you will be healed, and you will know why HIS HAND has not been lifted from you." So they returned the ark to Hebrews together with gifts of guilt offering, including five gold mice, so that error 錯 has metal 金 gold for pity 惜. “Take the ark of THE LORD and put it on the cart, and in a chest beside it put the gold objects you are sending back to HIM as a guilt offering. Send it on its way, but keep watching it.”謬䊮 error has worshiper $\supset$ and two cherubim $引$ on ark to carry. 㐱 represents people 人 such as Phinehas or Philistines to shed blood $三$ 部 mistake is to mistakenly take the ark marked by cherubim $引 \geqslant$ on it. The etymology of fault is golden calf near altar. This calf was ground to powder and thrown to water, so that fault 錯 has gold 金, altar 日, and either calf head 廿 or water waves $\approx$. In Exodus 32:20, "he took the calf the people had made and burned it in the fire; then he ground it to powder, scattered it on the water and made the Israelites drink it."

In 2 Samuel 6:6-8, "When they came to the threshing floor of Nacon, Uzzah reached out and took hold of the ark of GOD, because the oxen stumbled. THE LORD's anger burned against Uzzah because of his irreverent act; therefore GOD struck him down". In Leviticus 10:1-3, "Aaron's sons Nadab and Abihu took their censers, put fire in them and added incense; and they offered unauthorized fire before THE LORD, contrary to HIS COMMAND. So fire came out from THE PRESENCE OF THE LORD and consumed them". 惧 terror has two hands $*$ to handle worshiping tool 具. 误 暖 error has such a careless worshiper $\rtimes$ and altar 口. As cherubim sometimes represent ark or its temple, it is also a mistake 謬 to shed blood to take human life in temple. In 2 Kings 11:15 and 2 Chronicles 23:12-15, "For the priest had said, "Do not put her to death at the temple of THE LORD." So they seized her as she reached the entrance of the horse gate on the palace grounds".

Such astonishing biblical etymology of terror, error and horror reflects THE TOUGHNESS OF GOD. In Genesis 3:22, GOD said, "The man has now become like One of Us, knowing good and evil. He must not be allowed to reach out his hand and take also from the tree of life and eat, and live forever." Thus in divine dialectic philosophy, everyone must like GOD but cannot assume The Authority to be alike. For example, pope should not have murdered Giordano Bruno by fire, and no man can terrorize people to take away human life.

The fourth etymology of 谬臂 wrong involves raven and dove 羽 represented by wing (wng), 人 man (or), and blood or flood 三 (w), as in Genesis 6:11-14 human's violence triggered Noah's flood. The fifth etymology of 谬 wrong is for man to shed bird's blood to 
redeem $\sin$. In Leviticus 5:1-10, "If a person sins because he does not speak up when he hears a public charge to testify regarding something he has seen or learned about, he will be held responsible. Or if a person touches anything ceremonially unclean". "Or if a person thoughtlessly takes an oath to do anything". "When anyone is guilty in any of these ways, he must confess". "If he cannot afford a lamb, he is to bring two doves or two young pigeons to THE LORD as a penalty for his sin" "to sprinkle some of the blood of the sin offering against the side of the altar; the rest of the blood must be drained out at the base of the altar. It is a sin offering. The priest shall then offer the other as a burnt offering in the prescribed way and make atonement for him for the sin he has committed, and he will be forgiven." With pine as an affix of bird, repine has two birds, as the worshipers should offer at altar if they repine. With fe as feather and was blood, 寥 few has Tent of Meeting, wings, priest and blood, as birds are often offered more than one but their blood is very limited. 膠 resin/pitch was for "ark of cypress wood; make rooms in it and coat it with pitch inside and out". With elat of leather, 膠 gelatin is from heated leather. Elastic is the elasticity of leather. Elastin is a protein of skin. People are elated by hitting tambourine of ox leather in elation.

\subsection{Week}

\subsubsection{Seven Days to Match Seven Biblical Days}

Weekdays are days of work to wake, while weekend is end of being awake as day of rest. In Exodus 20:8 and Deuteronomy 5:12-15, "Six days you shall labor and do all your work, but the seventh day is a Sabbath to THE LORD your GOD. On it you shall not do any work, neither you, nor your son or daughter, nor your manservant or maidservant, nor your animals, nor the alien within your gates. For in six days THE LORD made the heavens and the earth, the sea, and all that is in them, but HE rested on the seventh day."

Although Monday was considered as moon day in the past, this article considers Monday as mono day, Genesis Day one. Mon means no light emission, as on Day one "darkness was over the surface of the deep". Moon has no light generation but reflects light. Tuesday is tue s day, two water day, as GOD said, "Let there be an expanse between the waters to separate water from water" on Day two. Wednesday is water condensation and new seed day. Wednes has dense, as GOD said, "Let the water under the sky be gathered to one place, and let dry ground appear." So dense soil formed and water condensed on Day three. Wednes has seed as GOD said, "Let the land produce vegetation: seed-bearing plants and trees on the land that bear fruit with seed in it". "The land produced vegetation: plants bearing seed according to their kinds and trees bearing fruit with seed in it", although Wednesday could be from ancient English Wodnesdaeg and German legendary angel Woden to coincidentally be wood day. Both letter $\mathrm{s}$ and $\mathrm{m}$ can represent wave. For instance, $\mathrm{M} / \mathrm{m}$ was written as $\mathrm{mm}$ in ancient Egyptian language and $w$ in proto-Semitic language and represents water and light wave. Previously thought to be Northern European legendary angel of thunder Thor and ancient Norse thórsdagr, Thursday is star day with stur of star and thurs of therm, of heat, as on the fourth Day all stars that "serve as signs to mark seasons and days and years" burn by thermonuclear reaction, and "HE also made the stars. GOD set them in the expanse of the sky to give light on the earth". Therm is the heat affix for thermal, thermometer, thermion, 
thermodynamics, thermos, thermostat and therm, unit of heat. Friday is fruitful fifth Day of fish and feather, as "GOD created the great creatures of the sea and every living and moving thing with which the water teems, according to their kinds, and every winged bird according to it kind." GOD blessed them and said, "Be fruitful and increase in number and fill the water in the seas, and let the birds increase on the earth". Saturday is taurus day when the creation had reached saturation on earth, bringing in very good satisfaction as GOD said, "Let the land produce living creatures according to their kinds: livestock, creatures that move along the ground, and wild animals, each according to its kind" on Day six. "GOD made the wild animals according to their kinds, the livestock according to their kinds, and all the creatures that move along the ground according to their kinds". "GOD saw all that HE had made, and it was very good." Saturn is legendary angel of agriculture in myth, and on this day man was created from earth. "GOD formed the man from the dust of the ground". "I give you every seed-bearing plant on the face of the whole earth and every tree that has fruit with seed in it." Grain is seed, suggesting that agriculture initiated at the end of Day six. Sunday is svn Day, Day seven, when ancient words were consonant dominant. Sunday is also no (un) water (s) day, as in Genesis 9:11 "I establish MY covenant with you: Never again will all life be cut off by the waters of a flood; never again will there be a flood to destroy the earth." Sunday was sunnandæg in ancient English, Northumbrian sunnadæg, ancient Saxon sunnun dag, Frisian sunnandei and Norse sunnundagr, and can also be no sunlight. In Luke 23:44, Matthew 27:45 and Mark 15:33, "darkness came over the whole land until the ninth hour, for the sun stopped shining." In Matthew 24:29 and Mark 13:24 "the sun will be darkened". In Luke 21:25, "There will be signs in the sun, moon and stars." "At that time they will see The Son of Man coming in a cloud with power and great glory." Sunday is German sonntag, Dutch zondag, Swedish söndag and Danish söndag, and can also be Son day. In Luke 6:5 and Matthew 12:8, "The Son of Man is Lord of the Sabbath", although HOLY FATHER IS LORD of all Days. Linguistic analysis supports the view that current calendar Sunday could also be considered as the seventh day Sabbath.

\subsubsection{Mystery of Genesis}

謎敦米 mystery has Word 言 to $世$ hover at waters $\nRightarrow$ and light 米, as in Genesis 1:2-5 "Darkness was over the surface of the deep, and THE SPIRIT OF GOD was hovering over the waters" and in Genesis 1:14-19 GOD said "Let there be lights in the expanse of the sky to separate the day from the night, and let them serve as signs to mark seasons and days and years". Mystery has MASTER'S aster. People narrow 眯 eyes 目 when sunlight is too shining 米. Secret has ester of aster, star. In addition, 类 represents $\mathbb{*}$ stop of flood $引$. Thus, 謎 mystery hints that cosmos formation and great flood hide great secrets of CREATOR.

奥奥 mystery has the house where Jesus was $\cap$, star 采 and worshipers' hands $k$. Even the orientation matches, as the star was "in the east" to guide magi from east and words often takes west as the upper direction because of ark in the Most Holy Place. Mystery is worshiping hands to follow a star to the house, "and the star they had seen in the east went ahead of them until it stopped over the place where The Child was". In 1 Corinthians 2:18-3:15, "we speak of GOD'S SECRET WISDOM, a wisdom that has been hidden and that GOD destined for our glory before time began." "The Spirit searches all things, even the deep 
things of GOD." In Romans 11:25-33, "I do not want you to be ignorant of this mystery, brothers, so that you may not be conceited: Israel has experienced a hardening in part until the full number of the gentiles has come in. And so all Israel will be saved, as it is written: 'The Deliverer will come from Zion; He will turn godlessness away from Jacob. And this is MY covenant with them when I take away their sins." "The great mission has been written in Luke 24:44-48, "The Christ will suffer and rise from the dead on the third day, and repentance and forgiveness of sins will be preached in His Name to all nations". Therefore, 懊 repentance has the star in mystery 奥. Linguists considered in the past that this word meant to regret a beast walking into home, as 采 was interpreted as footprint in 《Analytical Dictionary of Characters》 (Xu, 100-121 A.D.). However, now the whole world has to reconsider the entire etymology as biblical as possible. This article proposes starlight as additional interpretation of the traditional affix 米.

澳, land with boat, refers to where Jesus and disciples' boat anchored when He preached the mystery of the kingdom of heaven, as 奥 can also be interpreted as The Greatness 大 from the house $\cap$ marked by star 米. In Mark 1:16-20 and Matthew 4:18-25, “As Jesus walked beside the Sea of Galilee, He saw Simon and his brother Andrew casting a net into the lake, for they were fishermen. "Come, follow Me," Jesus said, "and I will make you fishers of men." At once they left their nets and followed him. When He had gone a little farther, He saw James son of Zebedee and his brother John in a boat, preparing their nets." In Mark 2:13-3:7 and Matthew 14:13-14, "He withdrew by boat privately to a solitary place." In Mark 4:1 and 5:21 "Again Jesus began to teach by the lake. The crowd that gathered around Him was so large that He got into a boat and sat in it out on the lake, while all the people were along the shore at the water's edge. He taught them many things by parables". In Mark 6:32-46 "Jesus made His disciples get into the boat and go on ahead of Him to Bethsaida". In Luke 5:1-11, "Jesus was standing by the Lake of Gennesaret, with the people crowding around him and listening to The Word of GOD, He saw at the water's edge two boats, left there by the fishermen". In John 6:1-14, "Jesus crossed to the far shore of the Sea of Galilee (that is, the Sea of Tiberias), and a great crowd of people followed Him".

Although miracles were abundant from genesis to Jesus' apostle John, we cannot expect much miracle nowadays. The so-termed modern physical miracles are typically false miracles prophesied by Jesus. In Matthew 24:24, "false prophets will appear and perform great signs and wonders to deceive". In Matthew 11:13, "For all the prophets and the law prophesied until John." John the baptist was the last prophet of GOD, although apostles were prophets of Son of GOD. However, when GOD decides not to rest further but to come back again and send angels ahead, physical miracles will resume in the future as prophesied in Revelations, but at those times we will be less able to distinguish between true miracles and artificial "miracles" from human beings in biblically prophesied false christianity, given such advanced science and technology.

\subsubsection{Convergence}

丙, the third stem of the heavenly stem calendar system, has convergence of waters ( $\mathrm{Du}$, 2019c). 陃朢 plain or course, is land movement 攴 when branches of water converged (人) 
to one place (一) at plain region $\sqsubset$ (together as 丙) to form coarse land, as on Genesis Day 3 (not earthly calendar day), "Let the water under the sky be gathered to one place, and let dry ground appear." 汇/龨 to converge has region (regeon of converge) $\sqsubset\ulcorner$, water, and angel cherub as holy bird 隹, although its alternative etymology is convergence of Noah's water. Thus, etymological analysis supports the geographic drift and land formation briefly described in Genesis, and science is consistent with bible and linguistics. Since dry land just appeared and beautiful plant had not been created, the land was coarse and plain, coarse is related to sea and earth, and plain has no (ni/in) plant as one of its multiple etymologies.

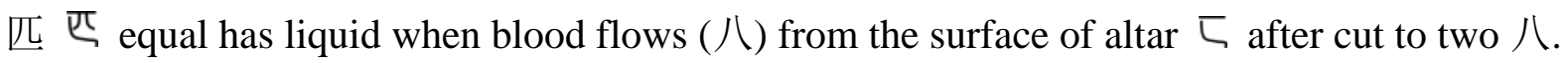
In addition, equal represents equal level of water (aque) liquid at $\backslash$ diversified regions $\sqsubset$ $ᄃ$. 鞭 flagella flogs and has leather 革 to fall on flagellant, as whip has blood flowing on board 王. Flog has blood flow. Scourge has serum to go on board's cover. Scour is the liquid on cover scoured. In Matthew 27:26, Mark 15:15 and John 19:1, "But he had Jesus flogged, and handed Him over to be crucified." In 1 Peter 2:24 "by His Wounds you have been healed". Whip can also simply be whip on hip, with $w$ representing the morphology of whip. Wiggle, has leg to go (gi) w. Addition of a person represented by letter R gives wriggle.

\subsubsection{Soil and Society}

To solidify has soil, 土 soil is solid 坚, and solid soil was from liquid lava oil. "Let the water under the sky be gathered to one place, and let dry ground appear." To isolate has soil and sea, and is separation of sea from soil. Isle and islet are isolated soil.

although 社 social has soil 土, sico is the main affix of social, society, associate, association, sociology and socialization. Sico and ciso are cise, cut in cis to two (second) and slices, and related to incision, scissor and sickle in etymology. In Genesis 15:10, "Abram brought all these to him, cut them in two and arranged the halves opposite each other" and "a smoking firepot with a blazing torch appeared and passed between the pieces". In Leviticus 1:8, "Aaron's sons the priests shall arrange the pieces, including the head and the fat, on the wood that is burning on the altar". Secondary is associated, with seco/sico as affixes of dual section in score 分. 社社 society has soil 土 and divine altar 示 with divided offering $八$ to represent Abraham and Moses' Israelite society, and also indicates sharing (平孚分 分) and distributing wealth in Acts 2:44-45. "All the believers were together and had everything in common. They sold property and possessions to give to anyone who had need." Christian society in Acts is the ideology to build heavenly kingdom on earthly soil. In Matthew 6:10 and Luke 11:2, "YOUR kingdom come, YOUR WILL be done on earth as it is in heaven".

\subsubsection{Flood and Blood}

To remind the everlasting covenant on forbidding shedding human blood after the flood, mosquito is etymologically related to human motion and liquid, sucks blood to remind the pain of blood, injects plasmodium to infect blood, and lays larvae in liquid. Lava is an affix related to liquid in lavatory, launderette, laundress, laundry launder, lavish, salve, salvage, salvation, salute, salutary, salubrious and salutation. Salve has lave as ointment and lotion. In addition to baptism, salvation involves water because in Leviticus 1:9 "he is to wash the inner 
parts and the legs with water, and the priest is to burn all of it on the altar", "an aroma pleasing to THE LORD". In Exodus 30:17-21, "make a bronze basin, with its bronze stand, for washing. Place it between the Tent of Meeting and the altar, and put water in it. Aaron and his sons are to wash their hands and feet with water from it. Whenever they enter the Tent of meeting, they shall wash with water so that they will not die. Also, when they approach the altar to minister by presenting an offering made to THE LORD by fire, they shall wash their hands and feet so that they will not die." In Leviticus 13-15 "But if, when the priest examines it, the mildew has not spread in the clothing, or the woven or knitted material, or the leather article, he shall order that the contaminated article be washed." "The person to be cleansed must wash his clothes, shave off all his hair and bathe with water". Shampoo has soap. 凌 shambles washes lambs slaughtered by priests. 沫䏚 bull $*$, as skinned bull is washed with water in Leviticus 1: 6-9.

"Whoever sheds the blood of man, by man shall his blood be shed; for in THE IMAGE OF GOD has GOD made man." Thus, deliberate is to bleed to irritate. In this "everlasting covenant between GOD and all living creatures of every kind on earth" in Genesis 9, "Everything that lives and moves will be food for you". Thus, deliberate is eater to bleed. Its etymology also fits Leviticus 7:27-17:12 and Deuteronomy 12:16-25. "But you must not eat the blood; pour it out on the ground like water." "If anyone eats blood, that person must be cut off from his people". Even eating blood must be cut off from Israelites, shedding human blood is certainly not allowed to "all living creatures of every kind". 眫 challenge has blood to bleed 血 to be in halves 半, as the divine secret (sect er) is to segregate people (er) to two sections, eternity and death. Challenge has allele 半, one of the two halves, which also means one of the pair of parallel genes in genetics. 挑衅 challenge is to bleed (血) to ignite the selected (挑) half (半) in fire (兆, 火) of hell after change. In contrast, challenge also has hall and hal of half , as who challenges falling angels will be segregated as the other half to heavenly hall with angels. The creation of free mind is double edged sword, and it matters eternal life or death to choose either word or sword, and either physical sword or Word as spiritual sword.

昭雪 to vindicate has divine indication, and avenge has even and most of heaven, as the loved half will enter eternal life, but the other half will be eliminated by eternal fire. The venge of revenge, avenge and vengeance is eg even, go in halves. 分 segregation has anger 忿, anger is danger to avenge, and rage is in segregation. 惱 Wrath is thermo Fury Future Fire 《 to thwart and thaw evildoers as warned in Malachi 4, Romans 1, and 2 Peter 3. "Surely the day is coming; it will burn like a furnace. All the arrogant and every evildoer will be stubble, and that day that is coming will set them on fire," says THE LORD ALMIGHTY." "THE WRATH OF GOD is being revealed from heaven against all" the people of impiety and wickedness, "who suppress the truth". Friar Giordano Bruno would rather be fired by any murderer who was not servant in love but stumbling stone than be divinely fired in the future if not defending Jesus' Sonship and scientific truth "understood from what has been made, so that people are without excuse". "You ought to live holy and godly lives as you look forward to the day of GOD and speed its coming. That day will bring about the destruction of the heavens by fire, and the elements will melt in the heat. But in keeping with HIS promise we 
are looking forward to a new heaven and a new earth, the home of righteousness." In Romans 12:19, "Do not take revenge, my friends, but leave room for GOD'S WRATH, for it is written: "It is MINE to avenge; I will repay," says THE LORD." In Hebrews 10:30, "It is MINE to avenge; I will repay," and again, “THE LORD will judge his people.” In final judgement, 神 GOD will 审判 judge both halves 半, as definitively announced through bible.

Liquid is related to squash, sequel and sequence with derived aquatic affix, when sUcc/ssUc is full of curves to represent water 《. 顺 《署 succumb or succeed is for water to recede after flood. Successive and sequential are for water to continue. Suction and suck are to take liquid and give rise to sucker, suckle and suckling. Succulent is juicy. 这 such has $\xi$ water and human $\mathbb{*}$ of the affix $之$ (毒). Squelch has lequ, quaff has qua, quell is no leque, and quit is quil - , no liquid.

In addition to water, the aqua/aque/aqui/liquid/fluid affix $\$$ often represents blood. 濁 opaque's aque is blood. 寧學, tranquil and peace, has $\boldsymbol{J}$ liquid blood from worshiping utensil 표 in front of Tent of Meeting $\cap$. $\bar{\zeta} \bar{\zeta}$ loss is less with divided offering 二 and flock's blood flow $\boldsymbol{\top}$, as one of its multiple etymologies. 污 squalid has liquid blood $>$. 污 dirt is such blood to tarnish and the leftover gotten rid of from altar.

"Solomon answered all her questions" to queen of Sheba in 1 Kings 10:3, so that question is queen's question. In 2 Chronicles 9:1, "When the queen of Sheba heard of Solomon's fame, she came to Jerusalem to test him with hard questions." Bathsheba, queen of David, was in (en) liquid (eque, water) to bath. In 2 Samuel 11:2, "From the roof he saw a woman bathing". Cedar is trade, as in 1 Kings 5:6-11 "So give orders that cedars of Lebanon be cut for me." "My men will haul them down from Lebanon to the sea, and I will float them in raft by sea to the place you specify." "In this way Hiram kept Solomon supplied with all the cedar and pine logs he wanted, and Solomon gave Hiram twenty thousand cors of wheat as food for his household, in addition to twenty thousand baths of pressed olive oil. Solomon continued to do this for Hiram year after year." Merchant has chariot as in 1 Kings 10:28-29 "royal merchants purchased them from Kue. They imported a chariot from Egypt for six hundred shekels of silver", although merchant's main etymology is to exchange. To buy and burn (bus) incense is business (Du, 2019c).

\subsubsection{The Ninth and Tenth Heavenly Stems 壬 and 癸}

Besides seven biblical days and a divine day that match the first to eighth stems of the ancient heavenly stem calendar system ( Du, 2019c), the ninth heavenly stem 壬年 is human 人 above earth 土, and the tenth stem 癸 apparently represents separation of people to two $\psi *$ on heaven 天, to match the last day of the rebuilding of spiritual temple by Jesus by three symbolical days (辛壬癸). Jesus will separate the selected wheat from destroyed weeds in final judgement with GOD and angels. 揆 to suppose has the mutually opposing steps $\Psi \mathbb{\Psi}$, and suggestion is to guess which section to step to (gu/ge). 葵 sunflower always turns toward sunlight, as Jesus Is "The True Light that gives light to everyone" in John 1. Its flower resembles sun and radiating light, as in Matthew 17:2 "He was transfigured before them. His Face shone like the sun, and His clothes became as white as the light”. 睽 to stare has star to stare at sunlight and is to separate. Sunflower has many seeds, as when you sow good seeds 
in good soil to pass tests, you will live forever. Sunflower seeds are roasted, since 烤 roast has test 考, and to roast is to assort in future divine astrological time. GOD even tested Abraham for him to offer his son at altar. The creation of sunflower is in predestined implication to Jesus' parables and Life.

\subsubsection{Climate}

The etymology of climate and related words such as seasons, cloud, wind, rain, thunder, hail, snow, ice, dry, wet, precipitation and dew have been presented (Du, 2019b/c, 2020a-c). 寒

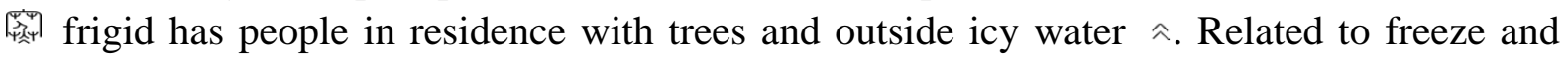
frozen, 霜 frost has eye 目 to the fruit of tree 木 in forest, as in Genesis 3:2-8 "When the woman saw that the fruit of the tree was good for food and pleasing to the eye, and also desirable for gaining wisdom, she took some and ate it." "Then the man and his wife heard THE SOUND OF THE LORD GOD as HE was walking in the garden in the cool of the day". 霧䨱 mist misses laboring 力 ₹ man 矛 when rain 雨 had to stop, as “GOD had not sent rain on the earth and there was no man to work the ground, but streams came up from the earth and watered the whole surface of the ground”. 霧 fog has $\mathrm{f}$ 力 to go 矛. By z N rotation, hazy and haze are no human. Consistent with astrophysical archaeology "and no shrub of the field had yet appeared on the earth and no plant of the field has yet sprung up", no plant to generate $\mathrm{O}_{2}$ (oxygen) from $\mathrm{H}_{2} \mathrm{O}$ (water) was consistent with lack of condensed water as rain.

Although ancient people thought that cloud 雲, rain 雨, snow 雪, frost 霜, mist 雾, dew 露, hail 雨, sleet 霰 and thunder 雷 were different entities with very limited knowledge of water ecosystem, these words all share identical affix on top, indicating that they were divinely created to match three phases of water. 神 GOD and lightning 电 have overlapping structure, as in Exodus 19:11-20:18 "On the morning of the third day there was thunder and lightning, with a thick cloud over the mountain". Then THE LORD said to Moses, "Make an altar of earth for ME and sacrifice on it your burnt offerings and fellowship offerings, your sheep and goats and your cattle" or "make an altar of stones". Therefore, 雷 雷 thunder is full of burnt altars 田 and cattle 畜. 霰 sleet has sliced offering.

\subsection{Biblical Son and Persons}

\subsubsection{Adam and Eve}

The systematical bilingual match in etymology to Son of GOD, biblical people, prophets and priests has been extensively presented ( $\mathrm{Du}, 2019 \mathrm{a}-\mathrm{c}$ and 2020a-g, and the rest of this article). This section presents additional examples. 抑灯? to inhibit and prohibit has $⿻$ w hand of Adam or Eve $? \pi$. To inhibit is in habit. Hands of Adam and Eve led to inhibition in habit of Eden garden. Forbid, forbade and forbear have $\mathrm{f}$ as $\boldsymbol{w}$ and b+vowel as two people (or). Adam and Eve forfeit life for the exhibited fruit of wisdom, and forfeit is of fruit. Industry is men in dust, as "through painful toil" Adam would work on ground. The alternative etymology of industry is to construct Tent of Meeting for priests to enter into.

我 own or mine has hand 手 to hold plowing tool $E$. 饿 famine has mine 我. 娥, young woman, has own 我, as in Genesis 2:23-3:21 "This is now bone of my bones and flesh of my flesh; she shall be called 'woman', for she was taken out of man." 蛾 moth is from the own 
worm $\imath$ as it undergoes metamorphosis. In etymology, 我 goose has ego 我, and swan has own (awn), as goose has relatively stable spouse, its relative swan 天鹅 has spouse for life as Adam and Eve, and its related Mandarin ducks live in pair as a couple, which are symbols of marriage and love in many cultures. Goose has mouth and very long neck reminiscent of Eden serpent. Goose is alert, as Eve should have been in full alert of temptation. Goose can live and multiply in colder environment, as GOD "was walking in the garden in the cool of the day, and they hid". Goose also has self osteo with such growth on head as bone of bone and flesh of flesh.

莓 berry has per and every 每. 梅 plum blossoms in cold winter and has human (人) mother (母) tree (木), as after plucking the forbidden fruit Eve was "in the cool of the day" in Genesis 2:4-3:8. 霉 mould has rain 雨 and human 人 mother 母, as "GOD had not sent rain on the earth and there was no man” to clone Eve, but human 人 Eve's arrival 到 gave Adam great misfortune 倒霉. Mould colonies resemble flower of plum blossom छ. In bilingual biblical etymology, 霉 mould has blom of blossom and plum 梅.

In Genesis 3:19 “for dust you are and to dust you will return". Thus, 士 human is earth 土 related to the affix hum of Latin. To exhume is out of earth, posthumous is after earth, humid is dim on earth, and humble is dust. For example, the righteous man Job, who was severely attacked, claimed most humbly in Job 42:6 to "repent in dust and ashes", although the attacks were certainly not his problem to repent at all.

\subsubsection{Cain and Abel}

Broil has brother's oil while the other brother worked soil. 穀 策 grain has $\mathbb{R}$ worshiper's

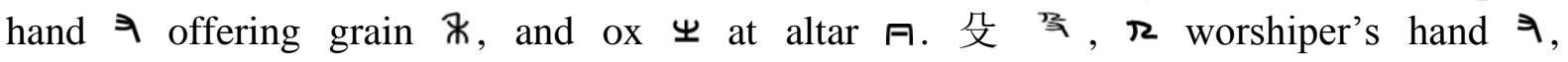
surprisingly means killing, because in Genesis 4:2-16 "Abel kept flock, and Cain worked the soil. In the course of time Cain brought some of the fruits of the soil as an offering to THE LORD. But Abel brought fat portions from some of the firstborn of his flock. THE LORD looked with favor on Abel and his offering." "So Cain was very angry". "While they were in

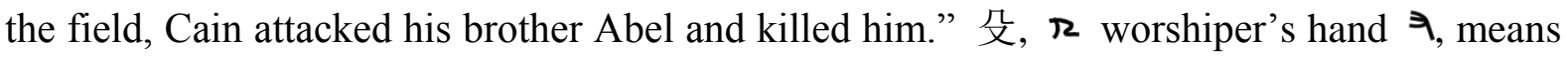
killing, also because of Noah's flood. 摧/毁 to destroy by storm has ark $⿴$, killing 殳, the affix of rainbow 虹, Ararat mountain 山, hand $\neq$, and raven or dove as bird 隹. In additional interpretation, to destroy is destruct, or dis Troy. Several words with Cain's story as etymology, such as accident, fugitive, forgive and pardon, have been presented ( $\mathrm{Du}, 2020 \mathrm{c})$.

With divided offering at altar above fire 黑, 黥 黑京 is to tattoo skin of a criminal in exile, as GOD put a taboo mark on Cain and Cain built a capital city 京. Cain said that" I will be a restless wanderer on the earth". LORD banished him but showed mercy," if anyone kills Cain, he will suffer vengeance seven times over." "Then THE LORD put a mark on Cain". Therefore, label has Abel. "Cain was then building a city, and he named it after his son Enoch.” This city of Enoch was Cain's capital.

\subsubsection{Noah}

Numerous words are derived from Noah's flood in etymology (Du, 2019b/c and 2020a/e). 筹 to prepare has 寿 longevity and 小小 pare (pair), as "a male and its mate" is a pair and at about 
600 years old Noah was required to "Take with you seven of every kind of clean animal, a male and its mate, and two of every kind of unclean animal, a male and its mate, and also seven of every kind of bird, male and female, to keep their various kinds alive". "You are to take every kind of food that is to be eaten and store it away as food for you and for them." 藤 vine has vessel 舟 $\Rightarrow$, 火 fire, ${ }^{2}$ two hands and a plant affix $\psi *$, as out of ark Noah "sacrificed burnt offering" and "proceeded to plant a vineyard".

\subsection{4 匽 as a Hidden Affix to Reflect Ishmael and Moses}

匽皇, to flee, has female 女共 Hagar, who was driven away by her mistress on a feast 宴 in Genesis 16-21. 宴 banquet has to ban female 女 who quit tent $\cap$, as Abraham held a great feast, but Sarah said to Abraham, "Get rid of that slave woman and her son, for that slave woman's son will never share in the inheritance with my son Isaac.” The mistress distressed Abraham greatly. But GOD told Abraham to "Listen to whatever Sarah tells you". Hagar and Ishmael “wandered in the desert of Beersheba”. 偃 姬, to put down, is for woman 女 to lay down man 人 near well of water $\odot$ along migration $L$, as "When the water in the skin was gone, she put the boy under one of the bushes." "GOD opened her eyes and she saw a well of water. So she went and filled the skin with water and gave the boy a drink."

In additional etymology, 匽匮, to flee and hide, has Moses' mother and sister as women 女 to hide Moses in a basket $\odot$ floating on Nile river. 堰 bank has Pharaoh's daughter 女 to rescue baby Moses from this basket $\odot$ near Nile bank, when Moses' mother and sister waited on land 土 around that region ᄃ. In Exodus 1:22-2:3, Pharaoh gave this order to all his people: "Every boy that is born you must throw into the Nile". "When she saw that he was a fine child, she hid him for three months. But when she could hide him no longer, she got a papyrus basket for him and coated it with tar and pitch. Then she placed the child in it and put it among the reeds along the bank of the Nile.” Thus, in bilingual biblical match, 宴 banquet links to bank 堰. 匽, to flee and hide, gives rise to mole 鼠, which lives underground to hide, 蝘 cicada whose larva lives underground, and 蝘蜓 gecko that runs and hides.

\subsubsection{Joseph to Prophesy Starvation}

In addition to the several etymologies of hunger, starvation and famine 饿/饑 for twins Esau and Jacob and their several names (Du, 2020a/c), 饉 to starve has taurus (species Bos taurus) and 英 cow near land 土 of water “ for Joseph to prophesy. To starve has to stand near river to eat 食, because in Genesis 41:1-32 Pharaoh said to Joseph, "In my dream I was standing on the bank of the Nile"..."seven other cows, ugly and gaunt, came up out of the Nile and stood beside those on the riverbank. And the cows that were ugly and gaunt ate up the seven sleek, fat cows." "The seven lean, ugly cows that came up afterward are seven years, and so are the seven worthless heads of grain scorched by the east wind: They are seven years of famine.” 革 ox is related to leather 革 革, originally drawn as ox with horns, head, torso and legs (Xu, 100-121 A.D.). 饉 starvation is 革 ox to 食 eat at land 土, an indisputable biblical etymology to the spiritual miracle of prophet Joseph. 僅 only has lean ox $\forall$ 英, as only Joseph could interpret this dream. 


\subsubsection{Etymology of Tomb, Cemetery and Burial}

陵楼 tomb has the affix of mobility 官追, $\Psi$ offering on altar, $儿$ cut to two to indicate worship, and $₹$ footstep. In definitive etymology, tomb has mob of mobility, mot of motion, and tom of anatomy to cut to two, because disciples moved in motion into and out of the empty tomb of Jesus (Matthew, Mark, Luke, 1st century, John, 1st century a), and Jacob instructed his relatives, "I am about to be gathered to my people. Bury me with my fathers in the cave in the field of Ephron the Hittite, the cave in the field of Machpelah, near Mamre in Canaan". When Jacob passed away, "Joseph directed the physicians in his service to embalm his father", carried the mummy and went up from Egypt all the way to Canaan, and buried Jacob in Machpelah's cave. Joseph himself also said, "GOD will surely come to your aid, and then you must carry my bones up from this place." In Joshua 24:32, "Joseph's bones, which the Israelites had brought up from Egypt, were buried at Shechem", so that coffin is off, cemetery is to migrate, and crematory is migratory (mecratory). 陸 鋉 earth has heat to burn offering $\Psi$ such as bull and heifer $\Psi$ 牛, indicating that all the earth must worship.

In additional biblical etymology, 墓 tomb is to moab with 莫 not known land 土. Why no land for tomb or no one (莫士) in tomb? For millenniums, linguists were puzzled by such words. However, Jesus' empty tomb and Moses' unknown burial provide definitive answers. In Deuteronomy 34:1-12, "Moses climbed Mount Nebo from the plains of Moab to the top of Pisgah, across from Jericho. There THE LORD showed him the whole land". "I have let you see it with your eyes, but you will not cross over into it." Thus, Moses could not (莫) enter the land (土). "HE buried him in Moab" "but to this day no one knows where his grave is". No (莫) people (士) knew his tomb (墓). Grave, ctrave, has travec of travel ₹追. Tavern is to travel in. From birth to burial, we find extensive bilingual mutual match to biblical etymology. Because the language of China was definitely created before biblical writing by Moses and apostles, and English was before the introduction of Christianity, both languages must have been divinely created ahead of time to predestinedly match bible and equally astonishingly, each other!

To buy is to bury and grave has cave in Genesis 23:1-20. "Abraham went to mourn for Sarah and to weep over her" and spoke to the Hittites, "Sell me some property for a burial site here so I can bury the dead". "If you are willing to let me bury my dead, then listen to me and intercede with Ephron son of Zohar on my behalf so he will sell me the cave of Machpelah, which belongs to him and is at the end of his field. Ask him to sell it to me for the full price as a burial site". "I will pay the price of the field. Accept it from me so I can bury my dead there". Ephron answered Abraham, "Listen to me, my lord; the land is worth four hundred shekels of silver, but what is that between me and you? Bury the dead." "Abraham agreed to Ephron's terms and weighed out for him the price he had named in the hearing of the Hittites: four hundred shekels of silver, according to the weight current among the merchants. So Ephron's field in Machpelah near Mamre - both the field and the cave in it, and all the trees within the borders of the field - was deeded to Abraham as his property in the presence of all the Hittites who had come to the gate of the city. Afterward Abraham buried his wife Sarah", so that 墳 $\pm^{+^{+*}}$ grave has earth 土, money 貝 and trees/grass to represent a field ${ }^{\psi^{*}+}$. Grave has eart of earth and treave of treasure 貝, the affix of wealth. In Matthew 27: "he was seized with 
remorse and returned the thirty pieces of silver to the chief priests" and "threw the money into the temple" and hanged himself. Then "they decided to use the money to buy the potter's field as a burial place". "That is why it has been called the Field of Blood", so that 墳 grave is to crave for treasure 貝. 愤 anger is bilingually related to grave (avger) 墳. 噴 to spray is to spray perfume or blood. Two main functions of consumed perfumes are to anoint and cleanse altar $⿴$, tabernacle or priest and to treat grave's body, but priests are banned to touch dead body, and who touched need to be cleansed. Altar is sprayed with blood. 香喷喷 means fragrant smelling, and funeral has perfume (erfune) or furnace to cremate.

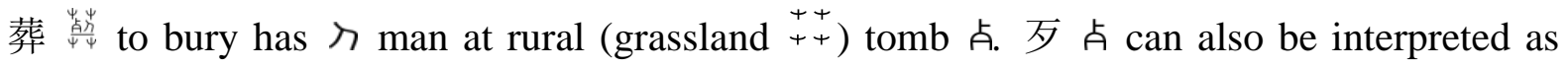
without (一) flesh $D$, and is an affix in 死/殁/歾/歿/殄 death, 残 damage, 殖 proliferation, 殊 misfortune and 殮/殯卢䨘 funeral. 殆 danger and 殂 death have altar 口 and primitive altar 且, as after "GOD went up from him at the place where HE had talked with him" represented by rising cloud $ठ$ above altar $\square$, “Jacob set up a stone pillar at the place where GOD had talked with him, and he poured out a drink offering on it; he also poured oil on it. Jacob called the place where GOD has talked with him Bethel. Then they moved on from Bethel. While they were still some distance from Ephrath, Rachel began to give birth and had great difficulty" "and was buried on the way to Ephrath". After this, Reuben stepped 4 against prohibition (一) to sleep with Jacob's maid wife 嬪 while Jacob pitched his tent $\nrightarrow$. Rachel consumed 殫 all her effort to give the birth, and Jacob 殞 lost this wife when Rebekeh's nurse also 殉 died around the time. "Now Deborah, Rebekah's nurse, died and was buried under the oak below Bethel.” By 殊 extremely special attack to kill 殲 by two people (人人) with weapon $\mathrm{t}$ in Genesis 34, “Simeon and Levi, Dinah's brothers, took their swords and attacked the unsuspecting city, killing every male. They put Hamor and his son Shechem to the sword

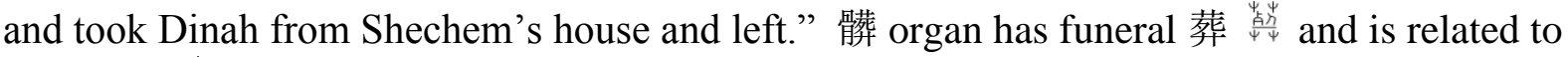
grave 墳 $土^{\mathrm{H}^{+}}$, as in Genesis 50:2-26 “Joseph directed the physicians in his service to embalm his father Israel. So the physicians embalmed him, taking a full forty days", and Egyptians treated organs when embalming bodies. 訃 obituary to condole 唁 has word/vocabulary 言 and lot $卜$, as in John 19:19-24 "Pilate had a notice prepared and fastened to the cross. It read: Jesus of Nazareth, The King of the Jews." Pilate answered, "What I have written, I have written." "They divided My garments among them and cast lots for My clothing".

\subsubsection{The Affix of P Corpse to Rebuild Temple}

In multiple biblical etymologies related to Christ, corpse has cross and sacred sarco, and is related to necrosis. Corpse is Person/person on cross, and has second person, because of afterlife and two co-crucified persons. In 1 Corinthians 15:40, "but the splendor of the heavenly bodies is one kind, and the splendor of the earthly bodies is another". In Luke 23:43 Jesus answered him, "Truly I tell you, today you will be with Me in paradise" for the

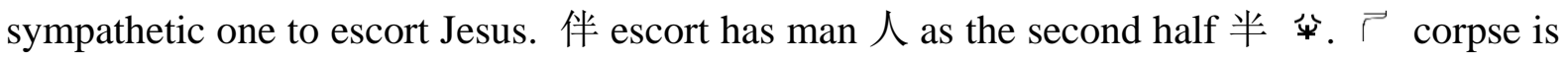
man $\pi$ in $90^{\circ} \mathrm{C}$ rotation in corp, corporation, cooperation and incorporation, to accompany as company and companion. Corpse has sepor of separation to sections, life and death. 皆 to die is to divide people $t$ to two groups $t \leftarrow$, piety and death. 分 's score shares identical etymology of separation with corpse, to evaluate the leaving crucifixers and scorning soldiers who separated Jesus' clothes to four portions 份. 
尸 26:61 and Mark 8:31-14:58 Jesus Christ claims to "rebuild it in three days" for a temple not made by human hands, when "He must be killed and after three days rise again". This is why 尸 is in temple 殿, room 屋, curtain 屏 and residence 居. Three days are a course 届. 屐/履 shoe has house, holy sanctuary $\overrightarrow{\ulcorner}$, as Moses must remove sandal when entering holy ground. 窟 cave is for Jesus to 出 go out of cave 穴, and has the most wrongful injustice 屈. 慰 comfort has room. 尉 lieutenant is the centurion who exclaimed, "Surely He Was The Son of GOD!" in Matthew 27:54, although additional centurions are also involved. 蔚, luxuriant and colorful, are tricolor biblical cords and colors of divine cloud. Since tricolor is blue, red and purple, 蔚蓝 is sky blue, azure. 澱 starch has tabernacle $\overrightarrow{\ulcorner}$. 殿 buttock is where the body part $\mathbb{D}$ of a priest most frequently touches temple 殿, as in Leviticus 24:1-4 “Outside the curtain of the Testimony in the Tent of Meeting, Aaron is to tend the lamps before THE LORD from evening till morning, continually. This is to be a lasting ordinance for the generations to come." Thus, priest has chair nearby to sit in order to tend lamp continuously, and 登 stool is utensil 豆 to share identical affix with lamp 燈. In 1 Samuel 1:9-3:18, "Eli the priest was sitting on his chair by the doorpost of THE LORD'S house". "One night Eli, whose eyes were becoming so weak that he could barely see, was lying down in his usual place. The lamp of GOD had not yet gone out, and Samuel was lying down in the house of THE LORD, where the ark of GOD was".

局局 station is tabernacle and altar. 属 affiliation has facility $户$. Affiliation has tail, 尾 tail is related to facility, and torso is related to corpse due to sanctuary. 層 layer is tabernacle's cover. 展 spreading is to spread thread-made curtains to cover Tent. 不屑, not to pay attention, is not at and into tent. 屑 also means residual as related to residence, as it also has 削 sliced offering 八. 屑 and 尾 and their translations have more than one etymologies, but these etymologies mutually match and all match relevant biblical events. These phenomena clearly reflect divine creation.

尼 nun is Miriam $飞$ who danced near sanctuary P. 泥 silt has Miriam 尼 and water ${ }^{\prime}$, and was carried by water flowing back in Exodus 14:23-15:21. "THE LORD brought the waters of the sea back over them". "Miriam the prophetess, Aaron's sister, took a tambourine in her hand, and all the women followed her, with tambourines and dancing." 妮, young or house woman, 昵 intimately followed Miriam. Although ash 烬 is a simplified word invented half century ago, it still matches bible, as it can be the ash in incense altar within shrine $\vec{~}$. 漏 leak (akle/acle) has rain 雨 in tabernacle $\vec{r}$ if not sealed well. 屡 often has Tent $\overrightarrow{\ulcorner}$ and is frequent offering at Tent.

犀 rhino has shrine 尸, as its remarkable horn resembles horns of incense altar within tabernacle or burnt altar in front of tabernacle. Oxpecker birds like to stay with rhino, because holy birds cherubim are near incense altar within shrine. GOD created rhinoceros and such symbiotic relationship as hint. 庶 means either drawer or one layer of food utensil, indicating that priest could use layered utensil to bring in twelves loaves of unleavened bread, no matter the table within tabernacle has drawer or not. In Leviticus 24:1-9, "Take fine flour and bake twelve loaves of bread, using two-tenths of an ephah for each loaf. Set them in two rows, six in each row, on the table of pure gold before THE LORD". 


\subsubsection{Samson}

In addition to the presented words with Samson as etymology (Du, 2020c/e and section “Etymology of Terror, Horror, Torture and Error"), 铐/栲 shackle and 拷 torture have 站, as Samson had 7 long hair not shaved, and 5 was either worshiper or no $(-)$ fermented liquid or spoon S. In Judges 13-16, the angel of THE LORD appeared to Manoah's wife that "you drink no wine or other fermented drink and that you do not eat anything unclean, because you will conceive and give birth to a son. No razor may be used on his head, because the boy is to be a Nazirite, set apart to GOD from birth, and he will begin the deliverance of Israel from the hands of the Philistines". Samson fastened a torch to every pair of fox tails, "lit the torches and let the foxes loose in the standing grain of the Philistines. He burned up the shocks and standing grain, together with the vineyards and olive groves" to scorch 烤. The rulers of the Philistines went to Delilah to lure, "See if you can lure him into showing you the secret of his great strength". So Delilah repeatedly 考䒺 quizzed Samson. Finally, Samson told her everything. "No razor has ever been used on my head," he said, "because I have been a Nazirite set apart to GOD since birth. If my head were shaved, my strength would leave me". "She called a man to shave off the seven braids of his hair" braids $\uparrow$ by hand $\supsetneq$. Head shaven by razor blade is bald, for the barbers to raid. Braid is to raid rabbi in addition to di bar, barbar. In barbarity, "the Philistines seized him, gouged out his eyes and took him down to Gaza. Binding him with bronze shackles, they set him to

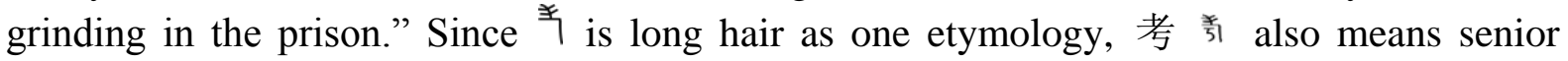
male in addition to exam, sometimes referring to deceased father.

\subsubsection{Etymology of Mock, Sarcasm and Satire to Son}

Earthly branch 辰 represents 7:00-9:00 in the morning before Jesus' crucifixion, for Pharisees or military soldiers to humiliate 辱 Son in that morning 朝 to 嘲 mock Him. Described in all four gospel books, in that morning "the governor's soldiers took Jesus into the Praetorium and gathered the whole company of soldiers around Him. They stripped Him and put a scarlet robe around Him, and then twisted together a crown of thorns and set it on His Head" and "mocked Him". Scorn has cron of crown and nor cross. Mock is to block emission, to block light to come out. Letter m represents light wave, as in Luke 23:44-45 "It was now about noon, and darkness came over the whole land until three in the afternoon, for the sun stopped shining.” 嘲 to mock has 崵, to block (一) light () of sun $\ominus$ (日, ○) (Du, 2019c and 2020d). No sunlight to dry is humid 潮, dim, and moist is to miss or omit light from cosmos, in addition to mist as additional interpretation. 押 to detain in custody of Jesus has 甲 $\uparrow$ of 嘲. Custody is to obstruct (odstyuct) body. 押 also means mortgage, related to the morning when Jesus was ransom. To mock is also to block motion from cross 十, as in Matthew 27:40 "You Who are going to destroy the temple and build it in three days, save Yourself! Come down from the cross, if You are The Son of GOD!" Consistent with obvious divine design, 潮 wet (tem) bilingually links to temple 廟, and 嘲 mock to mosqué 廟, which is translated as temple in English, mosque in Arabic, mosquée in French, and moschea in Italian.

卓/倬 eminent has no emission 昂 for the eminent Son, as sun turned dim when this world murdered Son. 悼 mourn has no emission 昂 or no (nor) motion, and has additional 
etymology from Jesus' prophecy for the end of time that all nations will mourn and "the sun will be darkened, and the moon will not give its light; the stars will fall from the sky". 朝 morning and mourn 悼 are a typical bilingual match. To grieve is not only grave but also for Eve to grieve after gripping forbidden fruit. Condolence has candle but can also be considered as not (ne) to burn, as stars will not give light and con/can is an affix of burning (Du, 2019b). Cannon fires. Volcano has fire in Latin. Condo and condominium have burning lamps. 桌 table is part of tabernacle in etymology, as it faces lampstand [tabernacle=table+cand burner (lamps)]. In Exodus 25:10-40:25, "He placed the lampstand in the Tent of Meeting opposite the table on the south side of the tabernacle and set up the lamps before THE LORD”. 绰 ample has wicks made of threads 亲 to be burnt off on lamps. Sufficient has fuse to burn sacrifices. 掉 fall is either no (l) flame (fla) or abnormal (l) flight of stars, which will fall when people flee and leap 踔 to mountains before segregation in parallel to eternal life and death. Alternatively, fall is similar to follow in etymology, and means motion by gravity. Gravity (ctravity, tractive) is to attract by force. With letter L as liquid wave sometimes, the two letters 11 of fall emphasize motion from one wave to another, from one location to another. 落䔄 fall or drop has water waves iil to fall from altar $\forall$, and division in parallel to portions $\psi+$.

讽 sarcastic is crazy (cras) 疯, as in Matthew 12:24 “when the Pharisees heard this, they said, 'It is only by Beelzebub, the prince of demons, that This Fellow drives out demons." In Mark 3:22 and Luke 11:15, "And the teachers of the law who came down from Jerusalem said, 'He is possessed by Beelzebub! By the prince of demons He is driving out demons." In Acts 26:24, "Festus interrupted Paul's defense. "You are out of your mind, Paul!" he shouted. "Your great learning is driving you insane."' Sarcasm also has cross (crss) and sarco, the affix of flesh, as the persecutors mocked Son's cross and sacrifice.

譏 to mock has chains that tighten Jesus, 么幺 ㅇㅇㅇㅇ, which in alternative etymology is textile (系京) of split curtain or clothes divided (幺 $\longleftrightarrow$, 家 S) by gambling soldiers with weapon 戈. In John 19:24, "They divided My garments among them and cast lots for My clothing." In Matthew 27:51, "The curtain of the temple was torn in two from top to bottom."

譏 has several 幾 for soldiers and clothes. 雞 rooster has these chains 幺(oo) to arrest Jesus,

and crowed three times that night in all four gospel books. 讽刺 mock also has 棘 thorn crown from soldiers. Satire has attire, Jesus' attire gambled by soldiers. Since the etymologies of all these words and all their translations are derived from Jesus, Christ is fully validated linguistically beyond statistical coincidence. This is an important discovery in linguistic archaeology and theology and surprising approach to validating the scripture.

"But the other criminal rebuked him. "Don't you fear GOD," he said, "since you are under the same sentence? We are punished justly, for we are getting what our deeds deserve. But This Man has done nothing wrong."” Deride, derision and despise have side Dier/dier. 藏

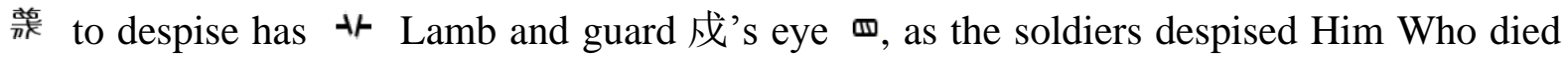
薨 on cross. $+*$ (Currently identical to the affix of plant + ) can also be hyssop, as in John 19:29 "they soaked a sponge in it, put the sponge on a stalk of the hyssop plant, and lifted it to Jesus' Lips". Vinegar is to disregard, as fermented things should not be offered, although 
this was not offered to GOD but Son of GOD. 酵 to ferment has vinegar 醋 and funeral 孝 to Son 子. Vinegar is acid to cide, acidic is acetic, acetic is citric, and citric is critic to criticize. It was ridiculous ridicule to cide (kill) Kid by ruler. Able to arrange Son to be killed to set the highest moral standard, who GOD cannot execute in final judgement, when HIS WRATH pours over the world?

\subsubsection{Jonah}

In addition to the presented words with Jonah as etymology (Du, 2019c and 2020c/e), 衡喚

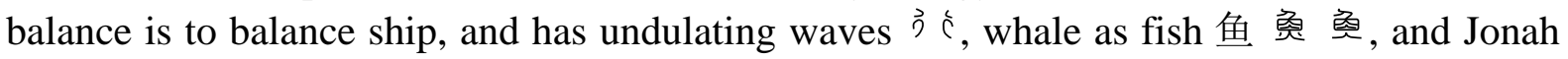
$\Uparrow$. 行 $\partial \dot{c}$ is walk and sail. Equilibrium has aqua liquid. In Jonah 1-4, “LORD sent a great wind on the sea, and such a violent storm arose that the ship threatened to break up. All the sailors" "threw the cargo into the sea to lighten the ship. But Jonah had gone below deck, where he lay down and fell into a deep sleep." "They cast lots and the lot fell on Jonah". He answered, "I am a Hebrew and I worship THE LORD, THE GOD of heaven". To "throw me into the sea," he replied, "and it will become calm". "Then they cried out to THE LORD, "Please, LORD, do not let us die for taking this man's life. Do not hold us accountable for killing an innocent man, for YOU, LORD, have done as YOU pleased." Then they took Jonah and threw him overboard, and the raging sea grew calm. At this the men greatly feared THE LORD, and they offered a sacrifice to THE LORD and made vows to HIM. Now THE LORD provided a huge fish to swallow Jonah". Because of the balance of weight and cargo, 衡 also means weighing apparatus. 拈 to cast has hand $\neq$ and offering on primitive altar 占. To cast has $\mathrm{sac}_{\text {rifice }}$ at altar (T). 卦 divination is from one land 土 to another land 土 in direction $卜$, and in ancient writing was forbidden step $\underline{\Psi} \underline{\psi}$ to land (such as Tarshish) 土.

"Jonah was in the belly of the fish three days and three nights" and "it vomited Jonah onto dry land. Then THE WORD OF THE LORD came to Jonah a second time: "Go to the great city of Nineveh and proclaim to it the message I give you."' The king of Nineveh "covered himself with sackcloth" and "Let everyone call urgently on GOD". The Ninevites believed GOD. They declared a fast, and all of them, from the greatest to the least, put on sackcloth. “HE took pity on them. HE didn't destroy them". Thus, ventral belly 腹 8 含 has the affix of body parts $\vartheta(\mathrm{Du}, 2020 \mathrm{c})$, Nineveh's residence $ᄉ$, and from one place $(\bigcirc$, coast) to another ( $\bigcirc$, Nineveh) (吕) by step $₹$. 腹 the ventral has vent (女, come or go to) of convention, venture and adventure. 8 拿 abdomen ( 8 domaen) is from one domain to another. 8 is letter B $B$ that represents relocation ( $\mathrm{Du}, 2020 \mathrm{e}$ ), close to previous consideration that letter B might represent house from Phoenician and Proto-Sinaitic sources related to Hebrew letter Beth (https://en.wikipedia.org/wiki/B). Because people in the capital city Nineveh put on sackcloth, 京 (卒) capital city has cloth 巾 $\uparrow$ of sackcloth in addition to building 人 and place $\square$ of belly 9 . "GOD provided a leafy plant and made it grow up over Jonah to give shade for his head to ease his discomfort". "When the sun rose, GOD provided a scorching east wind, and the sun blazed on Jonah's head so that he grew faint." Thus, 凉 cool, 乘凉, comfort in a cooler place at warm time, and 晾, exposure in the sun 日, all have capital city 京. 
Besides the gospel of repentance from Messiah and baptist John, the message of repentance from Jonah is a major biblical gospel from GOD, so important that Jesus talked about Jonah as one of the few prophets of GOD mentioned by name for the gospel of repentance (The other is baptist John "in the spirit and power of Elijah" as the predestinedly sent Elijah prophesied in Malachi 4:5). In Matthew 11:7-17:13, "For all the prophets and the Law prophesied until John. And if you are willing to accept it, he is the Elijah who was to come. Whoever has ears, let them hear." "Elijah has already come, and they did not recognize him, but have done to him everything they wished. In the same way The Son of Man is going to suffer at their hands." In Luke 11 and Matthew 12-16, a wicked "generation looks for a sign, but none will be given it except the sign of Jonah", but Jesus said, "for they repented at the preaching of Jonah, and now something greater than Jonah is here" to claim that He was not this prophesied Jonah whose sign "will be given", when John and all apostles performed abundant signs and miracles rather than "none will be given" then. In Matthew 24 and Mark 13, "when you see all these things, you know that it is near, right at the door. Truly I tell you, this generation will certainly not pass away until all these things have happened. Heaven and earth will pass away, but My Words will never pass away." 懺 to repent is related to fiber 纖 due to sackcloth. 悔 remorse has the affix of marine 海 water, because THE WORD OF THE LORD came to Jonah, "Go to the great city of Nineveh and preach". But Jonah "went aboard and sailed for Tarshish to flee".

Derived from Jonah 4 as the definitive etymology, 辨 新辛 to distinguish has hand $S$ and hardship 辛 to distinguish the left from the right, as "should I not have concern for the great city of Nineveh, in which there are more than a hundred and twenty thousand people who cannot tell their right hand from their left". To distinguish has digits to represent hand. Two types of hardships 辛辛 are in this word to distinguish sinful hardship from righteous hardship like the tribulations to Job (Unknown author, 1st or 2nd millennium B.C.). In James 1:12, "Blessed is the one who perseveres under trial because, having stood the test, that person will receive the crown of life that The Lord has promised to those who love Him." 讋 debate is better to be dead with words 言 and hardship 辛. “It would be better for me to die than to live." But God said to Jonah, "Is it right for you to be angry about the plant?"” 瓣 clove has cloud

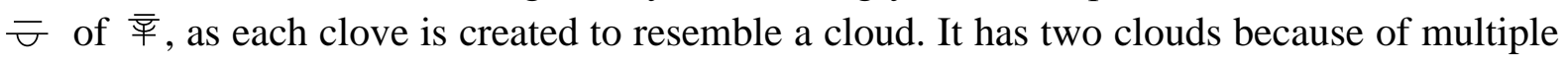
cloves in a flower.

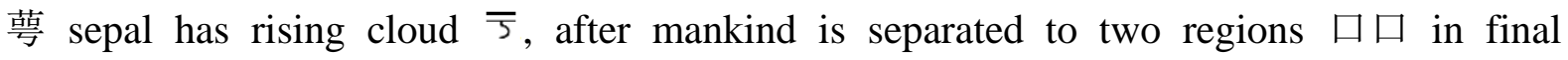
judgement. In addition to an affix of plant $\psi+$, 花 flower has transformation 化, which has human (人) and his/her transformed form ( $(\mathcal{H}$ ), consistent with spiritual ascendancy in cloud into eternity as described in 1 Thessalonians 4:14-18. 花冠闵 corolla or crown of flower has the coronal affix $\sqcap$ for man $r$ to be taken ${ }^{\ni}$ to cloud 二. Jesus received the most wrongful crown and bitterest cup, and the whole cloves and sepals of a flower resemble a cup $\vartheta$ preceding ascendancy in cloud to heaven. 華, magnificent splendor, meant flower in ancient time and has corolla, sepal and stem. 華's current version 华 has 化 transformation to heaven from cross 十, again indicating biblical etymology in modern time. In Matthew 6:28-30 and Luke 12:27, "See how the flowers of the field grow. They do not labor or spin. Yet I tell you that not even Solomon in all his splendor was dressed like one of these." 


\subsubsection{Mute Zechariah}

Dumb has worshiper's dubiety regarding an umbilical embryo, as in Luke 1:8-25 "Your wife will bear you a son, and you are to give him the name John." Zechariah asked the angel, "How can I be sure of this? I am an old man and my wife is well along in years." "And now you will be silent and not able to speak until the day this happens, because you did not believe my words, which will come true at their proper time. Meanwhile, the people were waiting for Zechariah and wondering why he stayed so long in the temple. When he came out, he could not speak to them. They realized he had seen a vision in the temple, for he kept making signs to them but remained unable to speak." So dumb is related to symbol, and mute is to meet angel in temple. 硜巴 dumb has cross झ, including the temporarily mute priest, 爸 father of the baptist who prepared the way for Lamb. 啞 mute also has 亞 to block exit of sound in all directions, because 亞 originally meant roads $\stackrel{ }{\mathrm{h}} \mathrm{r}$ blocked in all directions $\underline{\mathrm{I}}$ (Xu, 100-121 A.D.).

\subsubsection{Cornerstone Jesus and Rock of Church Peter}

Servant 僕 is the best kind of stone 璞. In Philippians 2:7, "He made Himself nothing by taking the very nature of a servant." "He humbled Himself by becoming obedient to deatheven death on a cross! Therefore GOD exalted Him to the highest place". In 1 Peter 2:4-7, "As you come to Him, The Living Stone-rejected by humans but chosen by GOD and precious to HIM - you also, like living stones, are being built into a spiritual house to be a holy priesthood, offering spiritual sacrifices acceptable to GOD through Jesus Christ. For in Scripture it says: "See, I lay a Stone in Zion, a Chosen and Precious Cornerstone, and the one who trusts in Him will never be put to shame." Now to you who believe, This Stone is precious. But to those who do not believe, "The Stone the builders rejected has become The Cornerstone," and, "a Stone that causes people to stumble and a Rock that makes them fall." They stumble because they disobey the message". As Peter was the directly defined rock of church, 僕 servant as the best kind of stone 璞 can also be apostle Peter. In Matthew 16:15-18, Jesus claimed that "I tell you that you are Peter, and on this rock I will build My church". Jesus praised Peter to the extent that church would be built on this rock, when Peter did not answer that Jesus was GOD, but defined Jesus as Son of GOD. 磐 然 rock has the fisherman Peter 矶, rock 石, ship man (舟人, 冬几) and 攵 death, as in John 21:18-19 “when you are old you will stretch out your hands, and someone else will dress you and lead you where you do not want to go." Jesus said this to indicate the kind of death by which Peter would glorify GOD.

\subsubsection{Town, City, County and Country}

Town is own tone, but in additional etymology town is own tower, and town is motion as two, because in Genesis 11:2-7 they said, "Come, let us build ourselves a city, with a tower that reaches to the heavens, so that we may make a name for ourselves and not be scattered over the face of the whole earth." But LORD said, "If as one people speaking the same language they have begun to do this, then nothing they plan to do will be impossible for them". Accents were split as divine tactic to balance each and every 个个 clan. 策 tactic has city 市, with additional etymology as every thorn 个个棘. “Because you listened to your wife and ate 
from the tree", "It will produce thorns and thistles for you, and you will eat the plants of the field". In renewed new testament law (as a parable to understand, marriage laws are different in history for close relatives and multispouses; gentles have law of conscience), Jesus requires us to be as one, as we can not weigh Authority alike to split each other, the typical biblical philosophy of dialectics.

責, obligate or responsible, has bound firewood or bovine offering 籼制 and the affix of wealth 貝 to donate (boate). 債 bond is the bondage to donate these, and related to donation in etymology. 積 to accumulate is to accumulate cattle and crop culture 禾 for altar, although altar also accumulates blood stains 漬. 績 is twisted yarn to weave tabernacle and priestly robe as accomplishment and merit. 績 merit has tricolor threads $\pitchfork$ 条. Priest has responsibility to wear turban, and because of radiant face Moses wore head veil 幘 in 臤 profound speech 嘖. 筫 bed has a typical bilingual match to debt 債, with two (b+vowel) people (D) in separation $\uparrow \uparrow$, as in Luke 17:34 "I tell you, on that night two people will be in one bed; one will be taken and the other left." Related to firewood as stick, 刺 prick is from stick, punch is related to a bunch of sticks, and to stimulate is to add stick and meal to flame of burnt altar, despite of additional etymology. To incite is to incinerate (cin), to instigate is to ignite, and instigation has ignition. Offered meal (mual) in flame is in alumnus and alumni, and classmate dissects meat. 階 class is related to scale, to section to two $t \nvdash$ near altar $甘$. Sections link scalar classes to escalator to escalate. 菄 jujube tree and thorn 棘 have pricks and sticks. Citron has pungent citric acid related to critic and critique. Citric is critic 責.

束 sheaf or bunch is a bundle of wheat or bound firewood, and also means to restrict sticks and branches or to restrain sheaves of grain. 辣 pepper has bundle 束, as stored peppers are bundled together to resemble firework grains, while a bundle of peppers flame next to flame, reflect 辛 laborious burnt, grain, sin, guilt and fellowship offerings. Pepper is peer after peer, and spicy is pile in cis as a typical transmigration of meaning, as its original etymology is spice. Priests wash 漱 them. 悚/竦 /dread/fear have 束 bundled wheat or weeds for the dreadful day of KING'S ORDER 敕, as in Matthew 13:11-24:30, Mark 4:11-32 and Revelations 2:26-14:19 at the divine weekend, "first collect the weeds and tie them in bundles to be burned; then gather the wheat and bring it into My barn." "How dreadful it will be in those days". "For then there will be great distress, unequaled from the beginning of the world until now - and never to be equaled again", "but for the sake of the elect those days will be shortened" and all nations of the earth will mourn when they see The Son of Man, Who will 揀 select the elected section and reject the other section. 揀 select $=\neq$ hand + 束 bundle + two sections ) (, and 速 velocity of star (aster) will be fast when "the stars will fall from the sky, and the heavenly bodies will be shaken", although there is additional etymology. 籁 is whistling from 束 bundled pipes. 懒 lazy is 悚 afraid in heart 个 to 負 carry bundled firewood 束. 癞 leprosy is lazy, as such patients are isolated outside and not allowed to serve in camp, so that 癞蛤蟆 toad was created to remind skin of leprosy, and has no (莫, a-) Tent of Meeting $\triangle$ and altar $\ominus$ for a worshiper to go to (pod-/pot- of topology or road). 赖 is to depend but also means to deny truth, for pedestrian $\gg$ to carry 負 load (and later on 束 bundle of firewood) but not (ne) trip (pe) far away (de), as in Joshua 9 "They went as a delegation whose donkeys were loaded with 
worn-out sacks...Then they went to Joshua in the camp at Gilgal and said to him and the men of Israel, "We have come from a distant country; make a treaty with us." "That day he made the Gibeonites woodcutters and water carriers for the assembly". 稗 weed or barnyard grass has wheat 禾, $\psi$ hand to indicate selection in separation 掉, and $P$, 日 sunlight $\Phi$ blocked $(-)$ and star $\ominus$ falling from sky $?$. In Malachi 4:5, "I will send the prophet Elijah to you before that great and dreadful day of THE LORD comes" in Temper 脾气 of Wrath, and this Elijah was John the baptist two millenniums ago. To choose has seco of second, and 仁 kind has second 二. In Matthew 20:16, "So the last will be first, and the first will be last."

市 city is hieroglyphic with multiple interpretations including offering at altar and city gate. 县 county of Ai has its king hanged 悬 at city gate, as in Joshua 8:29 “He hung the king of Ai on a tree and left him there until evening”. 縣 county has burnt altar 目, washing water 水 $《$, and 懸 hung curtain of Tent of Meeting 萦 (represented by tricolor yarn). 民 $P$ civilian or citizen has eye $P$, and $\succ$ arrow to represent a warrior or rural itinerary, as "people moved eastward, they found a plain in Shinar and settled there", and in Genesis 10:8-12 "Cush was the father of Nimrod, who became a mighty warrior on the earth. He was a mighty hunter before THE LORD". "The first centers of his kingdom were Babylon, Uruk, Akkad and Kalneh, in Shinar. From that land he went to Assyria, where he built Nineveh, Rehoboth Ir, Calah and Resen, which is between Nineveh and Calah — which is the great city."

Nation is native tone, one (oni/an) tone (tani/toni). "From these maritime peoples spread out into their territories by their clans within their nations, each with its own language." Thus, intonation is into nation, nation is into tone, and native, nation, natal, innate and nationality have the affix nat+vowel, the interchangeable tani, toni and tone. One nation is to narrate in one tone by tongue, either spoken or written. In Latin, natal is related to birth and tone, 產 birth has language 文, and 產 obstetrics is for tribe to step to, in order not only to have clan to go as the etymology of language (Du, 2019b), but also to match Rachel's birth to her son when her tribe was going. 產 birth has writing 文, also because of Luke 1:57-64. "When it was time for Elizabeth to have her baby, she gave birth to a son. Her neighbors and relatives heard that THE LORD had shown her great mercy, and they shared her joy. On the eighth day they came to circumcise the child, and they were going to name him after his father Zechariah, but his mother spoke up and said, "No! He is to be called John." They said to her, "There is no one among your relatives who has that name." Then they made signs to his father, to find out what he would like to name the child. He asked for a writing tablet, and to everyone's astonishment he wrote, "His name is John." Immediately his mouth was opened and his tongue set free, and he began to speak, praising GOD."

The affix tion is toni, one (oni) or into, the state of entry into Tent of Meeting. State is both man at altar and to state a statement in phonetic or written tone. State's initial bone version

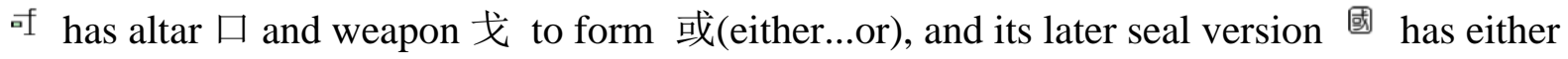
holy or no (一), altar 口, weapon and border 口. In three etymologies, 國 nation is weapon to guard holy altar within border, 或 alternative decision of either altar $\square$ or weapon 戈, or weapon within a border without altar, as three different stages of nations: pious nation, deviating nation, or violent nation without piety. To stop weapon 止戈 is military 为武, to limit military, as cultural philosophy consistent with the view from Christ (Zuo, First half 
millennium B.C.). The second stage occurred in 1 Samuel 7:13-8:21, to choose either to worship GOD THE KING or an earthly king to fight for them. When his people wanted to appoint a king to lead them, LORD told him, "it is not you they have rejected, but they have rejected"..."their KING" as an extremely TOUGH CLAIM. This was why in additional etymology country is to counter in contrary, and nation is anti. However, before this decision 國 country should be related to county 县/郡, district 區 and province 省 with burnt altar 目/ 口. Letter T represents altar, related to ancient Sinaitic and Phoenician to resemble burnt altar's bronze network 十. Counter is er cut on, as on such a counter worshipers cut or put bull. In Ezekiel 40:39, "In the portico of the gateway were two tables on each side, on which the burnt offerings, sin offerings and guilt offerings were slaughtered." 婁占 count has Abraham's altar $\square$ (Du, 2019c), and is either to count Abraham's five offerings "a heifer, a goat, and a ram, each three years old, along with a dove and a young pigeon" in Genesis 15:9, or for priest to count the number of offerings, because different numbers of offerings are offered at different rituals and festivals. For instance, for the festival of weeks in Leviticus 23:18-19, "Present with this bread seven male lambs, each a year old and without defect, one young bull and two rams. They will be a burnt offering". "Then sacrifice one male goat for a sin offering and two lambs, each a year old, for a fellowship offering." Nearby countries, from Egypt to Philistine to Moab to Ai, all had kings much earlier than Israelites, because Israelits' KING did not like their choice of an earthly king although this king was allowed later on. "Samuel told all THE WORDS OF THE LORD to the people who were asking him for a king", but they did not listen to him and still wanted an earthly king to "fight our battles". This king Saul was bewildered and divinely replaced later on, although in righteousness he finally sacrificed as a biblical hero to defend Israelites and fully respected GOD as the circumcised to take away his life. 國 country shares identical structure with 惑, bewilder or mislead, as the people was misled by their desire to win battles rather than acknowledging THE ONLY KING. Bewilder is be countryside. Misleading is earthly leader in mistake.

\subsection{Additional Affixes of Motion}

\subsubsection{The Affixes 乍 and Wh for Whether to Move in Restriction}

In addition to affixes of footstep systematically presented ( $\mathrm{Du}, 2019 \mathrm{~b}-\mathrm{c}$ and 2020a-e), the affix 乍䏍 has $\curlywedge$ man - not to move along a way $L$, and represents restricted motion. 窄 narrow is not to freely pass through a cave 穴 when entrance is narrow. Narrow can also be interpreted as narrow as arrow. Messiah told the followers to "Make every effort to enter through the narrow door" of heaven, in other words, faith and action. 榨 squeeze is for people $\lambda$ to press liquid, olive oil or grape juice, to move in a way $h$ against resistance - . In Numbers 18:27-30 and Deuteronomy 15:14-16:13, "Your offering will be reckoned to you as grain from the threshing floor or juice from the winepress." In Isaiah 63:2, "Why are your garments red, like those of one treading the winepress?" 作 to do or work is for Israelites to squeeze olive oil or press grape juice. Noah planted a vineyard for wine 酢 in Genesis 8:15-11:2. 阼 is restricted stairway at eastern side of hall. 痄 mump has restricted movement 乍 in isolation because of infection. 


\section{Mll Macrothink}

International Journal of Linguistics

ISSN 1948-5425

2020, Vol. 12, No. 5

This affix of restricted motion is also in 炸, blow and blast, as dynamite is not in free motion but in restricted package for 乍 abrupt explosion. 炸blow's 1 is - (no) and bow is mobile , and blast is not to pass freely. Alternatively, dynamite was tightened to arrow to be shot with bow. Explode, explosive and explosion's explo is not (1, - ) to go (po, pose, pode, ) out (ex, exit). Explosion is blocked movement of dynamite powder. To expose is to pose out, when Moses and Aaron came out of Tent of Meeting to be exposed to the assembly. This linguistic analysis solves the semantic origin of blast and explosion.

乍 云 (Seal version) 齿 (Bronze version) is also $\curlywedge$ people's restricted activity after $h$ flood stops - Its bone version $\uplus$ is water wave. 《Analytical Dictionary of Characters》 correctly interpreted it as relevant to 人(man)亡(go away), although restricted motion is its biblical etymology. 怍 remorse has people moving after water ceased, as people was regretful about how and why it could be such heavy loss, when 怎 how has $\curlywedge$ 人 human and water $h$, and 咋(why) has hydro water $\uplus$. 祚 blessing has less flood as "GOD blessed Noah and his sons". Noah sacrificed meat 胙 after flood receded. "Then Noah built an altar to THE LORD and, taking some of all the clean animals and clean birds, he sacrificed burnt offerings on it." As water decreased and flood receded, decrease has recede. 柞 is great tree with no (一) further migration for man, because Abraham's great tree is at his destination region. The nut of oak resembles Abraham's tent. 昨 yesterday was the day flood $h$ stopped ( $一$ ) for ancestors $\curlywedge$ to migrate east "As men moved eastward", consistent with the consideration by the languages that great flood is old but Exodus is present, and consistent with the linguistic creation after flood, although current can be current of Red sea to cover horsemen.

诈 trick is related to trip from one place to another despite of no (一) trip, as in Joshua 9 "when the people of Gibeon heard what Joshua had done to Jericho and Ai, they resorted to a ruse: They went as a delegation whose donkeys were loaded with worn-out sacks and old wineskins, cracked and mended. Then men put worn and patched sandals on their feet and wore old clothes. All the bread of their food supply was dry and moldy. Then they went to Joshua in the camp at Gilgal and said to him and the men of Israel, "We have come from a distant country; make a treaty with us." "Three days after they made the treaty with the Gibeonites, the Israelites heard that they were neighbors, living near them." Then Joshua summoned the Gibeonites and said, "Why did you deceive us by saying, 'We live a long way from you,' while actually you live near us?" They answered Joshua, "Your servants were clearly told how THE LORD your GOD had commanded his servant Moses to give you the whole land and to wipe out all its inhabitants from before you." However, in the dialectical new testament, GOD does not tell anyone to wipe out any inhabitant anymore, when no nation is directly called.

In Numbers 13:33-14:43, "We saw the Nephilim there (the descendants of Anak come from the Nephilim). We seemed like grasshoppers in our own eyes". "We should choose a leader and go back to Egypt", although Israelites should have believed THE LEADER telling them to purge corrupted clans. LORD prevented their migration into Canaan and initiated their forty years of wandering in desert for a generation. "Then we turned back and set out toward the desert". Thus, 蚱 grasshopper has inhibited relocation, in addition to hopping abruptly like an arrow. 


\section{$\triangle$ Macrothink}

The prefix wh matches 何 虂, with < as water (w) and $\pi$ as human (h), although worshiper near altar $\boxminus$ and rising cloud is another interpretation. Wh gives rise to who 何人, what 何事, when 何时, where 何地, why 何故, whether 如何, which, whatever, what so ever, whence, whenever, whereas, wherever, whichever, while, whoever, whose and whom. While navigating in flood and landing after flood, people might ask whether, where, when and what to whoever wherever they could reach. Wharf is where human leaves raft next to water. In Genesis 8:8-22, Noah sent out a dove to see whether the water had receded. 何 whether has $\pi$ Noah, cease $(-)$ of $く$ water, and thermal altar 口. "Come out of the ark, you and your wife and your sons and their wives." "Then Noah built an altar to THE LORD”. 气 weather has air flow $气$ and is related to water and thermal heat, as "HE sent a wind over the earth, and the waters receded" for Noah to heat burnt offering. "Whenever the rainbow appears in the clouds, I will see it and remember the everlasting covenant". "As long as the earth endures, seedtime and harvest, cold and heat, summer and winter, day and night will never cease". Wheat worker needs weather, and water washes for wholesomeness. In 1 Kings 17:1-18:45, Elijah anticipated precipitation after building an altar. Noah should have whiskers, although this Hebrew might not brew whisky when "he drank some of its wine". The sound of wind and flood interpret some words starting with wh, including whiz, whistle, whew, whiff, whimper, whine, whisper, whoop, whisk, whorl, whirl and whirligig. For instance, whimper 鸣 has raven 乌, and whine 鸣 has bird 乌, as Noah sent raven and dove to check on water.

\subsubsection{The Affix of Giant 巨 as Relevant to Migration}

The inhibited entry and wander in desert in circle is the etymology of giant 巨 $\bar{E}$, anti gi, against migration (g+vowel is a set of affixes to go, such as go and eg- of leg and geography), as all the native "people we saw there are of great size". 巨 $\overline{1}$ giant has curve > to wonder in desert, I direction of migration, and - two lands. 拒 to reject is to inhibit entry into Canaan. As divinely ruled, they had to turn back to wonder in desert, so that rule 矩 has the

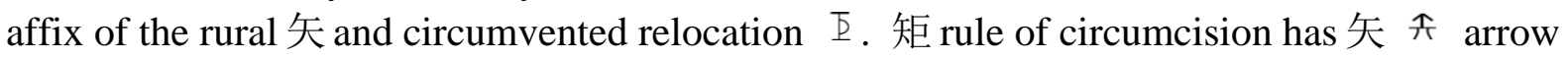
of archer Ishmael, who also lived in desert and once wandered in desert $\overline{\mathrm{B}}$.

距 distance is 钜 huge distance between the two lands Israelites wondered $\bar{~}$. 柜 closet is the cabinet of ark carried whenever Israelites set out in relocation, with torch 炬 at night. Torch has tour in route. 亘 lettuce's stem resembles bone as skeleton, with relocation $\overline{\mathrm{B}}$ and tele as distance 距, as in Genesis 2-3 “This is now bone of my bones and flesh of my flesh" but "GOD banished him from which he had been taken". 讵, how could, is how relocation could be like this. Etymology validates biblical record of giants.

\subsection{3 兆 Omen and the Human Affix 天}

乔喬喬 means both great high tree and relocation as an immigrant 侨僑 $大$, because of relocation of altar $\square$ and tent $\cap$ when "Abram moved his tents and went to live near the great trees of Mamre at Hebron, where he built an altar". Abram and Lot were ancient immigrants. 矫/矯 correction has relocation 喬 at the wild $\hat{*}$ as represented by arrow, as GOD rectified Miriam and priests corrected leprosy by relocating patients outside of camp. Bridge 桥橋 is ge ride B, $大$ man to go to ride from one place to another ( $\diamond, B$, 吕) [桥 
bridge; 骄 pride. Typical bilingual match]. 骄 pride is people in ride. Proud is people on road. At ancient time, people who rode on horse 基 were often proud at high rank, although it also involves donkey of the family of equidae ( $\mathrm{Du}, 2019 \mathrm{c}$ ), and links to words such as request to Rider Jesus or equestrian Moses who rode on donkeys. In 1 Peter 5:5-6 and James 5:6-7, "GOD opposes the proud but gives grace to the humble." "Humble yourselves, therefore, under GOD'S MIGHTY HAND, that HE may life you up in due time." "Submit yourselves then, to GOD". In Exodus 15:1, "I will sing to THE LORD, for HE is highly exalted. The horse and its rider HE has hurled". Human should be in humanity, and humble is blessed human. Noble is no blessing, although it can also be to bless on. In 1 Corinthians "HE chose the lowly things of this world and the despised things — and the things that are not - to nullify the things that are, so that no one may boast". 驱 quadruple horses to drive one chariot are 乘, which coincidentally means to multiply. Queer is related to equestrian Balaam's donkey. In Number 22:21-33, "When the donkey saw the angel of THE LORD, she lay down under Balaam, and he was angry and beat her with his staff." The donkey said to Balaam, "Am I not your own donkey, which you have always ridden, to this day? Have I been in the habit of doing this to you?" "No," he said.

妖, monster or demon, tempted Eve the woman 女 who moved $大$ from Eden garden. Monster and demon have motion. To admonish is to abandon demon and sin. 妖, sexually wicky as its second meaning, fits Sodom and Gomorrah, transnoted by Lot's wife and daughters as women 女 to flee away $大$. 天 $大$ is to pass away for Sodomers and Gomorrahers. People in these two cities tried to flee, and Lot and his wife and daughters strode with large steps in running and leaping 跃 to flee away. Lot must have run quickly 奔 蛮, which is related to elope and explore. Lot's daughters had engaged but fled and slept with their father. This can certainly be considered to elope, which has $t$ people to run. 沃, well watered rich land, originates from Genesis 13:10-13, as the whole plain was well watered like the garden "before THE LORD destroyed Sodom and Gomorrah". Lot needed to have coat/jacket 袄, as he "left Zoar and settled in the mountains" and "he and his two daughters lived in a cave".

In Genesis 18 right before Sodom's elimination, LORD and two angels appeared to Abraham and said, "I will surely return to you about this time next year, and Sarah your wife will have a son." "Abraham and Sarah were already old and well advanced in years, and Sarah was past the age of childbearing. So Sarah laughed to herself". Then LORD said, "Why did Sarah laugh"? "Is anything too hard for THE LORD? I will return to you at the appointed time next year and Sarah will have a son." Sarah was afraid, "I did not laugh", but LORD said, "Yes, you did laugh". Then GOD and angels "looked down toward Sodom, and Abraham walked along”. 笑 smile is to eliminate every people 个个天. Smile is also to miss elimination, as Abraham petitioned until the limit of ten righteous people were even not reachable. "Who smiles last, who smiles best". "Blessed are those who mourn, for they will be comforted". 飫 is well fed and full, $大$ human to eat 食 but pass away 天, as in 1 Corinthians 15:32 "If the dead are not raised, "Let us eat and drink, for tomorrow we die."” In Numbers 11:4-34, "THE ANGER OF THE LORD burned against the people" who asked for too much food other than 
manna from heaven. In the past millenniums, puzzled linguists thought that it was impossible that to be fully eaten 食 is to pass away 天, but bible provides its etymology.

The affix 兆 訬 is to cross water border. 怆 can also be raining fire. Its etymology of both water and fire is consistent with 兆's main meaning of omen. 水 water and 火 fire both overlap with 兆. 兆 s $\xi_{\epsilon}$ portent has man fleeing across water border $\varepsilon$, which can also be considered rising smoke. "LORD rained down burning sulfur on Sodom and Gomorrah" "like smoke from a furnace”. Lot fled 逃 and 咷 wept for the cities and his wife. 逃 㖄 to flee is either from one side of water to the other side after flood, or away from Sodom's fire. 眺 is to look into the distance from one side of water to the other, or look at Sodom on fire, as "He looked down toward Sodom and Gomorrah, toward all the land of the plain". 化 flirt is from the people of Sodom. 跳 is to leap from one side of water to another. cross line between two halves and was created to resemble fire, for Noah to char burnt offering after stepping (pe) out of ark (arch). 窈宨 good and graceful beauty was Rachel, who crossed the stream of Jabbok s st with 幺 Jacob and 幼 junior Joseph (Du, 2020e). In Genesis 29:17 "Rachel was lovely in form, and beautiful". Rachel had good looks 姿 as second daughter 次女 of Laban.

In additional etymology, 跳/跃/躍 leap is aple of temple, and jump is related to temple with cherubim 羽羽/隹, for Son 儿 to pass away 天, as in Luke 4:1-13 the devil led Him to Jerusalem and had Him stand on the highest point of the temple. "If You are The Son of GOD," he said, "throw Yourself down from here. For it is written: "HE will command HIS angels concerning you to guard you carefully; they will lift you up in their hands, so that you will not strike your foot against a stone.' " " Jesus answered, "It says: 'Do not put THE LORD your GOD to the test.' " Leopard is to leap. Although puma is from Inca, puma also has to jump.

\subsubsection{Footstep Affix 夋}

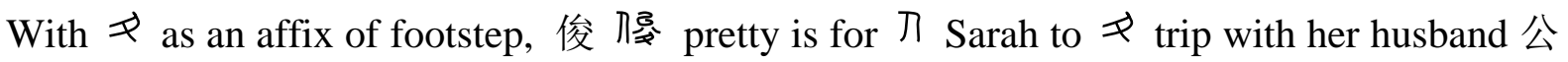
who cut offering in halves 八( Du, 2019a-c and 2020a-e). 竣塂, to finish, has fission 八 before 寽 human stops $¥$ at smoke of fire $\Xi$. In alternative etymology, it has 1 human and male 公交 to step away $₹$, as GOD drove Eve and Adam out after finishing creation of Eve from handsome 俊 Adam, who was abetted 唆 by Eve. To abet is bait. In additional etymology, abet is for two people to step out, a step, or without bet. 酸 sour is when ferment of vinegar 醋 finally stops $¥$, and is etymologically related to route and tour $¥$. 㾡 sore is pain and related to shoe, and pain is $₹$ step in or no step into a land. In multilingual biblical math, 悛 repent has 公 paternal and parental Adam. 悔 remorse has maternal mother 母 Eve. No ancestors could create words in this way for parent to repent and mother to remorse, clearly indicating divine creation to match biblical revelation. 畯 peasant officer was Adam, who “work the ground from which he had been taken”. 骏, fine horse, was Pharaoh’s $¥$ running horse 马 when $る$ wave of Red sea split 八. 浚 dredge is to split dregs of river to allow water to move. 梭 shuttle of wood 木 is for thread $る$ to move 又 between two sides 八. 峻 steep is for man 公 to stop $¥$ at mountain $山$. 焌 is a prevailing divination culture in Shang dynasty to 八 crack turtle shell on fire (火 and る), as additional evidence that the language 
originated without access to bible but astonishingly matches bible, as in Leviticus 19:26 GOD told Israelites that "Do not practice divination or sorcery", although this decree was not issued to Shang and additional nations.

\subsubsection{Tech Affixes}

As a new set of affixes of English, ect/tec/cet/etc match $\supsetneq$ hand's worshiping technique at altar攴支。支父 are main affixes representing offer with hand. Priests are experts in these

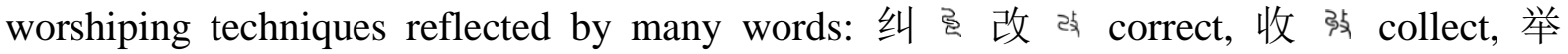

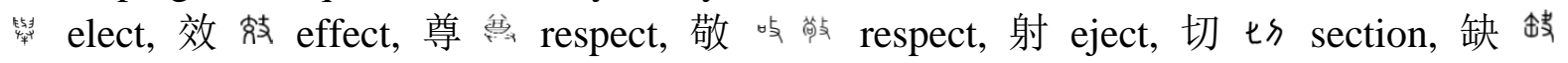
defect, 探/测 detect, 推测 conjecture, 察察 inspect, 慧 intellect, 教 弶 lecture or

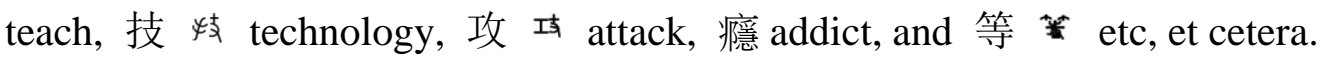

To correctly collect 收路 blue, purple or scarlet yarn and fine linen, including two twisted cords 2 , was described in Exodus 35:4-29, 26:1 and 27:18. "Make the tabernacle with ten curtains of finely twisted linen and blue, purple and scarlet yarn". 物 object is to handle offered bovine 牛. However, to object has 勿牛, no calf, as we must reject and deject golden calf as an idol. Subject, bus ject, has combustion of handled offering. Project supports offering. 射 ejection has marked hand 寸 $\mathcal{\vartheta}$ to handle blood injected into utensil and ejected from slaughtered ox. 受学 to accept has dact/ect as hand to offer. 授授 to confer has fingers of second hand $\stackrel{\pi}{\exists}$. 承产 to undertake has two hands $\Varangle \propto$. 得 to get has cet with 寸 $\rightarrow$ hand.

This set of tech affixes are related to the affix cate of indicate, replicate and dedicate, which can be interpreted as hand handling offered cattle $\forall$. Cater is to provide calf at feast. 奉 to dedicate has di dact cate, two dactyl hands $\& \rightarrow$ to offer cattle $*$ as tithe (十 deca of decade, decagon, decathlon, decalogue) in obvious etymology. In Leviticus 27:32, "Every tithe of the herd and flock - every tenth animal that passes under the shepherd's rod-will be holy to THE LORD."

誉譽 reputation and 兴興 prosperity have four hands $\stackrel{x}{y}$ or steps in coordination as coworkers to carry altar or ark. 信誉 credit is from DICTATOR (DICTER), and has DICT and DEIT as affixes of GOD as well as er as worshiper (Du, 2019a). Because GOD dictates, we cannot dictate, because to "be like GOD" was the exact reason for the loss of eternal life in paradise. In Genesis 3:5-23, "For GOD knows that when you eat from it your eyes will be opened, and you will be like GOD”. Our certified diet is heavenly manna, Word of GOD, because "Heaven and earth will pass away, but My Words will never pass away" in Matthew 24:35, Mark 13:31 and Luke 21:33.

穩 stability's 䔷 罢 is to 扛 carry poles of ark 工 with two hands ark, altar and table of tabernacle must be carried stably. 隱 conceal or latent has the affix of relocation $巨(\beta)$ to carry ark's poles 工 with two hands $r ?$, because in Numbers 4:5 "when the camp is to move, Aaron and his sons are to go in and take down the shielding curtain and cover the ark of the Testimony with it." In addition to concealing ark, the ark was also concealed behind curtain within Tent of Meeting in stable position when Israelites settled. In 
Exodus 40:21, "Then he brought the ark into the tabernacle and hung the shielding curtain and shielded the ark of the Testimony". Latent is at tent. In bilingual match, 瘧 addict has two hands $r$ (didact) to touch holy item under Tent, although only levites could touch. Levite priests should be addictive to carrying ark as honor, but other clans should not crave touching cherub (ave) of ark. Noah craved for ave, raven and dove of ark (arc), to bring salvation.

\subsubsection{Com as Coordination Affix}

As a common affix of English, com represents together and cooperation. One etymology of com is co move. Come is to move, welcome is to come to well as Rachel welcomed Jacob in Genesis 29:2-13, commune is to move between, comet is to move as a moving meteorite in motion, locomotion is to come, coma is unable to move in addition to somnia, comb moves through wool, accompany is to come together, commencement and commemoration are to come together, commerce is to move merchandise on water, compact is to gather together, competition is to compete for the speed to move, and comment is from Tent of Meeting that bans ordinary people. 令 command has to come from Tent of Meeting $\wedge$ 命. Community, communicate, communicant, comrade, company, companion, accomplish, commotion, common, commonplace, commit, commandant, commander, compress, compel, compulsion, committee, commission, commissioner, commissionaire, commissary, missionary, commodore, compensate, recompense and locomotive are derived words.

In Genesis 3:21, "GOD made garments of skin for Adam and his wife and clothed them" before they moved out of the plain in exile to complain the ancient serpent. Because of this relationship between the movement and woven garment, com is hieroglyphic o⿱ textile such as room's component in Tent of Meeting). 聯 to combine resembles 京宗. 聯 commonwealth has biblical clothing and meat as wealth. In Judges 14:12-20 Samson talked about such wealth related to his wedding, "If you can give me the answer within the seven days of the feast, I will give you thirty linen garments and thirty sets of clothes. If you can't tell me the answer, you must give me thirty linen garments and thirty sets of clothes." But it turned to tragedy for thirty men, although for wife to come to wedding with veil should be comic comedy. In Genesis 24:7-67 "She took her veil and covered herself" and "Isaac brought her into the tent of his mother Sarah, and he married Rebekah.” 組 compound and composed component are comprised of separated threads as composition. 綜 comprehend and comprehensive include all yarns in compendium. Combustible is textile. Priests come 来

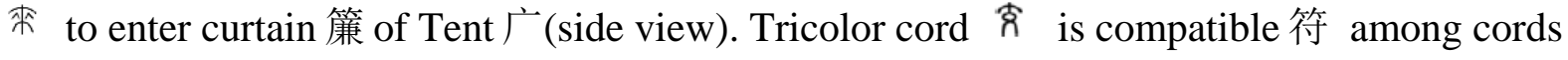
小ネ. Comet has long tail that resembles yarn. Priests are comfy and complacent, in comfort, composure, compliance and complaisance with ephod. Commerce trades thread and textile. 服 comply also means clothes. Commiseration is to tear clothes to halves (semi). To separate is to tear in pair. 率 rate and ratio are to tear apart offering $::$. Commode holds textile as commodity. 常 common, commons, commonalty and commoner have cloth 巾. 補 complement to compensate has an affix of clothes $k^{k}$ and bird as offering. 編 to compile piles together textile to compute 算 仦 cloths. Comfrey is purple 紫 flower. 紀 commemoration or consecration commencement has to put competent priest's garment 系 on 
himself 己 in Exodus 28:2-29:21. As compulsory requirement, "Aaron must wear it when he ministers. The sound of the bells will be heard when he enters the Holy Place before THE LORD and when he comes out, so that he will not die." "Make linen undergarments as a covering for the body, reaching from the waist to the thigh. Aaron and his sons must wear them whenever they enter the Tent of Meeting or approach the altar to minister in the Holy Place, so that they will not incur guilt and die."

\subsection{Textile}

\subsubsection{Etymology of Textile, Filament and Fiber}

Textile has to exit in exile, as in Genesis 3:21 "GOD made garments of skin for Adam and his wife and clothed them” before their exile. 縫䌌 to sew has the affix of textile 䋨 derived from twisted three-color yarn $\$$ 条, $\xi$ water of well watered garden, $\neq$ tree, and two people walking $\Psi$ ₹. This lineage was also in exile later. Ezra, Esther, Ezekiel, Daniel and related books all talked about or prophesied exiles.

慈 lenience has linen next to linen 鼓, as tabernacle and priests' garments are all linen woven, and Israelites and Nineveh people were forgiven when wearing linen sackcloth to repent (see section "Biblical Son and Persons", Moses 2nd millennium B.C.a-e, Unknown author 1st millennium B.C.b-d). In Deuteronomy 29:2-9, "But to this day THE LORD has not given you a mind that understands or eyes that see or ears that hear. During the forty years that I led you through the desert, your clothes did not wear out". "Carefully follow the terms of this covenant, so that you may prosper in everything you do."

With 号 (㕕 or 幺) of tricolor yarn 察糸系, 亂铜 perplex has both hands $\mathbb{2}$ to mix cord 了

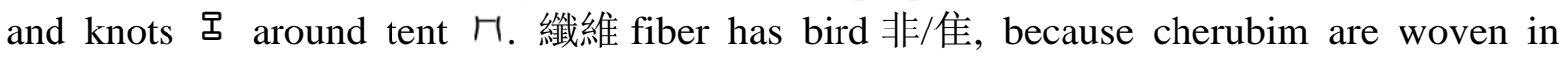
textile, and textile is related to cherubim, weapon 戈 and two people 人人 in exile, as after GOD made garments and "drove the man out, HE placed on the east side of the Garden of Eden cherubim and a flaming sword flashing back and forth to guard the way to the tree of life". In additional etymology, fiber is fried, filament has flame and meal at altar, fabric has fried fire, 纨 fabric has worshiper 丸, and 缯/缟/練 fabric has burnt altar 口. 簡 brief is fiber, three colored yarn of curtain of Tent of Meeting's entrance 門門. Curt is curtain, and terse has three-color cord $E$. To abbreviate, abate+brevi, has briev of brief, fiber.

\subsubsection{Etymology of Blasphemy}

Obscene and indecent sexual action, 猥裚, has fear 畏 to 执 hold clothes 衣, as in Genesis 42:18 Joseph told his brothers, "I fear GOD", and the fear of GOD prevented Joseph to allow a woman to lean close to him. 偎依, to lean close, has fear 畏 of clothes 衣. 裚渎 blasphemy is to take 执 and divide clothes 衣 (as indicated by the split 衣) and 卖 sell blood «, as in John 19:24, Matthew 27:35 and Mark 15:24, "they divided My garments among them and cast lots for My clothing", and in Matthew 27:3-4 "he was seized with remorse and returned the thirty pieces of silver to the chief priests and the elders. "I have sinned," he said, "for I have betrayed innocent blood."' Such words are consistent with the fact that Jesus is Son rather than GOD. GOD would not design such words to HIMSELF in routine utilization by human. Blaspheme has sphere 球, as 求's etymology is clothing 装 (Please see “The affix of 
球 global plea 求”). 裚 blasphemy's etymology also includes Matthew 26:65 and Mark 14:63, when high priest tore his clothes/ephod (indicated by do we need any more witnesses? Look, now you have heard the blasphemy".

In Leviticus 19:8-22:15, "The priests must not desecrate the sacred offerings". "Whoever eats it will be held responsible because he has desecrated what is holy". 櫭 穊 profane has a worshiper $\lambda$ and two priests $\lambda \lambda$ to take offering by hands $t \in$ from burnt altar $\forall$ to eat 既 (see section "Relationship of Textile with Tabernacle and Altar"), although $\phi$ \& also resemble forks, as in 1 Samuel 2:12-17 it was the practice of two priests Hophni and Phinehas that "whenever any of the people offered a sacrifice, the priest's servant would come with a three-pronged fork in his hand while the meat was being boiled and would plunge the fork into the pan or kettle or caldron or pot. Whatever the fork brought up the priest would take for himself. This is how they treated all the Israelites who came to Shiloh. But even before the fat was burned, the priest's servant would come and say to the person who was sacrificing, "Give the priest some meat to roast; he won't accept boiled meat from you, but only raw." If the person said to him, "Let the fat be burned first, and then take whatever you want," the servant would answer, "No, hand it over now; if you don't, I'll take it by force." This sin of the young men was very great in THE LORD'S SIGHT, for they were treating THE LORD's offering with contempt." Later, when they disrespected ark by carrying it to battlefield for military success, the wife of Phinehas, was pregnant and near the time of delivery. When she heard the news about the ark of GOD and her father-in-law and her husband, "she went into labor and gave birth, but was overcome by her labor pains. As she was dying, the women attending her said, "Don't despair; you have given birth to a son."” She named the boy Ichabod, saying, "The Glory has departed from Israel". Thus, profane is related to orphan. Profane is to offend.

\subsubsection{Silkworm and 蜀}

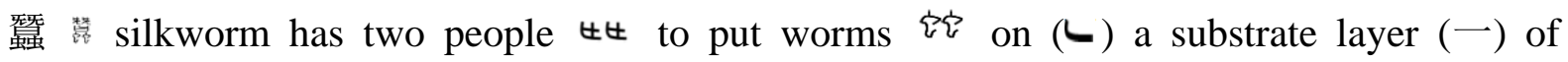
container $\sqcup$. 蜀 9 署, the province well known for silk industry, has eye $₫$, worshiper 7 and \& worm. Silkworm eats mulberry leaves and makes cocoon coverings. 桑 桑 mulberry has hands to grip from tree, symbolizing Adam and Eve's gripping of forbidden fruit. silkworm also has two people $\uplus$ at burnt altar $\bullet$, and its simplified version 萤 means 天 heavenly worm 虫, consistent with divine creation. 梓 or 桑梓, native place, has 木 tree and hard labor 辛, as in Genesis 3:1-19 “with painful labor you will give birth" and "through painful toil you will eat food from it all the days of your life". 亲 family has 辛 hard labor at burnt altar with 八 division of calf 牛 $\%$ and firewood 木, and family has flame and meal, for kin to kindle offering. People of China write and plant these trees to express the respect of native place, make silk cloth, a major industry at ancient time, and should realize that all these relevant words originate from bible in etymology.

In bilingual match, 濁睍 opacity has optic 目 $\propto$, and opaque has aque water in, as 7 Moses held staff of snake $\dot{\text { 虫 to }}$ look at Nile river and turn water to opaque blood 血 in Exodus 7:15-24. "Go to Pharaoh in the morning as he goes out to the water. Wait on the bank of the Nile to meet him, and take in your hand the staff that was changed into a snake." 
"With the staff that is in my hand I will strike the water of the Nile, and it will be changed into blood." "The fish in the Nile died, and the river smelled so bad that the Egyptians could not drink its water.” 混浊 opaque also involved plague of insects 昆虫 gnat, fly and locust to Nile river. To depend has step (pede of speed and pedestrian) and stop (end) at Eden, as Adam and Eve depended on GOD. However, 依 to depend also has 人 human dress 衣 to step (pend) away (de) from Eden garden, and 園 圈 garden has garment 衣 芯, as GOD made clothes for them before their exile, so that they had to depend on themselves later on. To depend gives rise to dependent, and independent is not (in) dependent. 獨 solitary is for people to listen to serpent 虫 to step away from Eden, and has 蜀's 9 and 7 , as 7 Adam was isolated from GOD after temptation from $₹$ to open eyes $₫$ to "be like GOD". GOD concerns about this likeness, as man may not have the ability of GOD to distinguish good and evil but only choose the good. To be alike includes exercising the authority that only GOD possesses, such as preemptively taking human life - a right GOD reserves in new testament to final judgement, after Son of GOD established law of love on behalf of GOD to further strictly forbid killing between each other. Without Jesus' predestined arrival and sacrifice two millenniums ago to reconcile mankind to GOD, no one would be able to live forever. Thus, we must cherish this free grace as the historical opportunity to perform required good deeds to accompany faith (James, Matthew, Mark, Luke, John, Paul, 1st century, Du, 2020f). 燭 candle has alne of alone and lona of lone 獨, to give light from a single source.

The two people (夫夫) should not have listened to the serpent's slander 嘅 to 僭 overstep authority to eat forbidden fruit. The garden where the two people hid 潜 was well watered (i), when "they hid from THE LORD GOD among the trees of the garden". Their descendants swam underwater 潜 to cross the Tigris and Euphrates. Without wearing hairpin 䙃 to tighten long hair, they could stumble at cliff or riverbank by blocked eyesight and be difficult to harvest, hunt and escape from predators because of the created hair.

\subsubsection{Etymology of Inheritance and Heritage to Tear and Desperate}

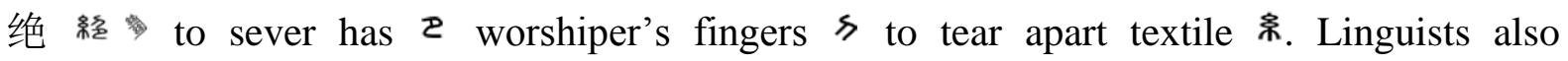
interpret it as cut off by knife, \'s derived meaning (Xu, 100-121 A.D.). To desperate is to tear apart dress, despair is separation in pair, decease is to cede, and disaster is to tear attire to two in addition to dis aster prophesied. In disaster or decease of relatives, Israelites tear attire in etymology. This is why to inherit or succeed 繼 heir and heritage are to tear. 斷 break is to tear and has the two cut parts of cloth, and fragment is to tear garment. In Genesis 37:34, when Jacob saw Joseph's bloody robe and thought his son had been torn by beast, "Jacob tore his clothes, put on sackcloth and mourned for his son many days". One etymology of succeed is to cede suit, as David successfully succeeded Saul in 1 Samuel 15:26-16:13. "“'You have rejected THE WORD OF THE LORD, and THE LORD has rejected you as king over Israel!" As Samuel turned to leave, Saul caught hold of the hem of his robe, and it tore." Miserly is to cut spending in halves, but misery is to tear clothes in halves (semi) with extensive biblical examples, although serum+y (bloody) is its alternative etymology. 


\subsubsection{Curtain's Affix 曼 and Blood}

曼 is cloth 缦 of curtain 幔 $\cap$ covering ark's two poles $=$ or separating the western Tent of Meeting from the eastern burnt altar $\mathbf{m}$. In Numbers 4:5-6, "When the camp is to move, Aaron and his sons are to go in and take down the shielding curtain and cover the ark of the Testimony with it. Then they are to cover this with hides of sea cows, spread a cloth of solid blue over that and put the poles in place." 慢 slow is to hang the shielding curtain or wrap ark with curtain. 蔓 tendril resembles the spreading lines of blood sprinkled on the curtain of Tent of Meeting. In Leviticus 3:2-4:34, "the anointed priest shall take some of the bull's blood and carry it into the Tent of Meeting. He is to dip his finger into the blood and sprinkle some of it seven times before THE LORD, in front of the curtain of the sanctuary." "He is to take some of the bull's blood and with his finger sprinkle it on the front of the atonement cover, then he shall sprinkle some of it with his finger seven times before the atonement cover. He shall then slaughter the goat for the sin offering for the people and take its blood behind the curtain and do with it as he did with the bull's blood" in Leviticus 16:11-15. Tendrils spread on a wall, resembling blood lines on the curtain.

漫 "䁏 is all over or to overflow. " water overflows throughout cut offering around altar m, and Aaron sprinkled blood « all over atonement cover behind curtain 幔. 馒 is bread on table in front of the shielding curtain to ark and behind the curtain to entrance. 镘 trowel spreads plaster on wall. 熳/爛/絢 brilliant refers to bright triple colored curtain. 䯭 beautiful hair of girl 嫚 resembles the three colored threads. 鳗 eel resembles each piece of curtain (28 or 30 cubits x 4 cubits) swaying. In Exodus 26:2-36:15, "All the curtains were the same size - twenty-eight cubits long and four cubits wide" . For the cover over tabernacle, "All eleven curtains were the same size — thirty cubits long and four cubits wide."

\subsubsection{Relationship of Textile With Tabernacle and Altar}

綺, figured woven cloth, has altar 口. 練 trial (altir) and tribulation have altar 田. 绫/绸/绢 silk cloth has 捐 donated $+\Phi$ offering and altar 口. Woven with plural colors and decoration, 錦検 brocade has forbidden Tent of Meeting $\mathbf{A}$, burnt altar with division 手, firelight from

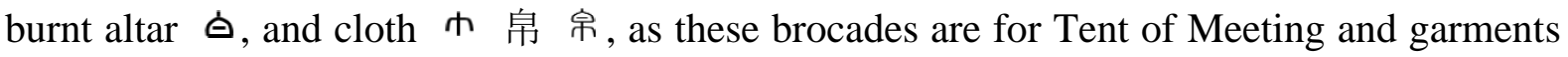
of priests. In Exodus 28:1-38:23 "Make sacred garments for your brother Aaron, to give him dignity and honor." These include "a breastpiece, an ephod, a robe, a woven tunic, a turban and a sash". "The curtain for the entrance to the courtyard was of blue, purple and scarlet yarn and finely twisted linen - the work of an embroiderer." Both brocade and embroider have robe.

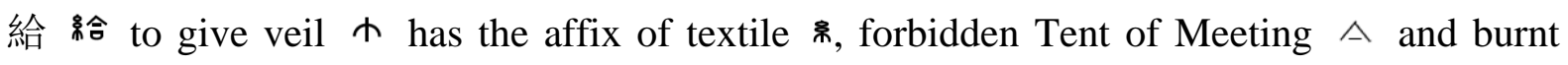
altar 口, as in Exodus 35:21-26 "everyone who was willing and whose heart moved him came and brought an offering to THE LORD for the work on the Tent of Meeting, for all its service, and for the sacred garments." "Every skilled woman spun with her hands and brought what she had spun - blue, purple or scarlet yarn or fine linen. And all the women who were willing and had the skill spun the goat hair." To bring is to bring string. 带 to bring is to bring veil/cloth $\uparrow$ 巾. 
㧅 knit has knife 刀, and stitch 㧅 has blade 刃. 幡 banner has altar with bronze (branNe) grating 田 to burn (bern) an offer 燔. In Numbers 2:2 “Israelites are to camp around the Tent of Meeting some distance from it, each man under his standard with the banners of his family." Consistent with all the instruction to weave curtains of tabernacle and garments of priests in Exodus, 織 䋨昔 knit has voice 音 to 类 armed Israelite. Its simplified version, 织 knit, is to 八 divide near altar 口, indicating that biblical etymology still occurred half century ago, because the divinely designed framework of linguistic structure allows recombination of existing affixes. A typical example is SPIRIT/Spirit/spirit 灵 with $₹$ HAND/Hand/hand on lake of fire ' $心$. If passing final judgement, spirit will live forever.

Numerous words related to tabernacle and altar have been presented (Du, 2019a-c and 2020b/c). 詢 to consult has burnt altar. Consulate has burnt altar. Consular was priest. Insult is sin altar, as who insults should redeem at altar. 慰慰 comfort has Tent of Meeting's roof $\vec{r}$ and $火$ fire from altar. Formal is flamor, flame of altar in flambeau, flamboyant and flamingo. 尉 officer, captain, lieutenant and warrant officer, guards and carries Tabernacle, camp and tents. In Numbers 1:2-3:32, "You and Aaron are to number by their divisions all the men in Israel twenty years old or more who are able to serve in the army. One man from each tribe". "The leader of the families of the Kohathite clans was Elizaphan son of Uzziel. They were responsible for the care of the ark, the table, the lampstand, the altars, the articles of the sanctuary used in ministering, the curtain, and everything related". In Nehemiah 4:16-18 when rebuilding the temple, "the other half were equipped with spears, shields, bows and armor. The officers posted themselves behind all the people of Judah who were building the wall. Those who carried materials did their work with one hand and held a weapon in the other, and each of the builders wore his sword".

茴 caraway is a spicy plant with finely divided and feathery leaves that mimic wings of cherubim on ark carried away in return 回 to Canaan. Its crescent shaped achenes resemble horns of offerings. 回 represent ark and enclosed tablets. In Isaiah 28:25, "When he has leveled the surface, does he not sow caraway"? When carrying ark, we have to be chary and careful 恮. 荃 aromatic plant has the forbidden Tent of Meeting $\underline{\Delta}$ where incense altar is. In front of Tent of Meeting, 牷 pure colored ox was sacrificed, and Moses commented 诠, prayed for healing 痊, and weighted measurement 銓, as in Exodus 30:34 “Take fragrant spices-gum resin, onycha and galbanum - and pure frankincense, all in equal amounts”.

檔 document is to double cut donated meat. To cut open 敞㫾 inside courtyard is often 常, and often is of entrance and of net of altar. 倘, if, has altar 口 and offering in fission 八. 赏 gift is fission near altar 口. 刀 s knife resembles fingers, and has fine as penalty 罰 劒 with the affix of knife I or finger $久$. To cut offering is defined by regulation 則, which has split cattle as the affix of wealth 貝 cut by knife J. Final, finis, finish, finical, definite and confine are already cut. 掌 palm has lamb of ALMIGHTY MAJESTY and 手 hand of custom 尚, and hand is on head, as for biblical custom priests "lay his hand on the head of the offering" in front of Tent of Meeting, as written in Leviticus 1:4, 3:2-12 and 4:4-15. 堂 hall has halves, as bull is cut in halves after blood shedding. 螳螂 mantis was created to resemble 郎 man near worshiping hall 堂 to pray. 蚌 坢 mussel and clam's shells have separating lines 
to resemble sliced sections of muscular offering or connected curtains that constitute camp's cover. Thus, mussel is related to muscle and museum in etymology.

種 seed has burnt altar田. 㹯 seedling has man $\Uparrow$ offering grain $\approx$ at burnt altar $\mapsto$. 秆 桿 stalk has burnt altar 日 and ox in addition to grain 禾. 稿 stalk has burnt altar 口. 薦 to refer has deer 鹿's divided hoof or antlers $\psi \Psi$, as deer is among the several types of clean food referred in Deuteronomy14:4-21. To refer has two (d+vowel) er, deer. "These are the animals you may eat: the ox, the sheep, the goat, the deer, the gazelle, the roe deer, the wild goat, the ibex, the antelope and the mountain sheep. You may eat any animal that has a divided hoof and that chews the cud."

退敨 to retreat has to stop « flood 乡 and go $\searrow$ to altar $\boxminus$, after water retreated. 退 quit is to retreat liquid quite quickly (退 quit; 很 quite). 即 㸃, at present, has priest 品 and the prototype of burnt altar with fire $\hat{8}$. Thus, present is related to priest in etymology. Priests section 節 offering in festival 節. 卿 知 sir has two worshipers near an altar with fire. 既 eaten has food 食's 艮 to owe 欠, because when hunter Esau ate lentil stew in exchanging birthright, he owed Jacob birthright. He was irritated with sigh 慨 after Jacob formally got this birthright from Isaac's blessing, and wanted to kill Jacob, who would sigh 慨 over his threat (Moses, 2nd millennium B.C.a). 跟, rear foot, was where Jacob held Esau in delivery "with his hand grasping Esau's heel". Foot's F is hand, and too is two twins, despite of additional etymology. Plant's foot is its root 根 to eat. 溉 to irrigate has water related to cattle's shed 厩, as in Genesis 30:38 "Then he placed the peeled branches in all the watering troughs, so that they would be directly in front of the flocks when they came to drink." 厩 stable is where cattle eat. 限 restrain is to Jacob's strain of spotted or speckled cattle.

\subsubsection{The Etymology of Temptations}

引 引l lure has rural and ruler's affix Ur as archer (Du, 2020a), and is to draw a bow 弓 [U or re $\mathrm{U}$ as $\mathrm{w}$ ] to shoot arrow I, or not (I) to be worshiper $\overrightarrow{3}$, as Esau was seduced by temptation in temper to threaten Jacob. 惑 to entice is to twin related to twice, tie and either 或. 念 to incite has two people 从, including Eve to Adam, or Rebekah to Jacob. Weapon has bow and part of spear. To seduce in seduction has separation and segregation away from DUCT, the affix of THE LEADER GOD (Du, 2019a). 䬶 bait (dait/adit) has diet 食 and the affix 耳 of audit 闻, auditor, audiotape, audience 聽, audition and audacity 敢, because Eve and Adam should not have listened to the serpent and eaten the forbidden fruit. Temptation is for Jesus to jump from temple.

\subsubsection{The Affixes of Use 用 and 角 at Altar}

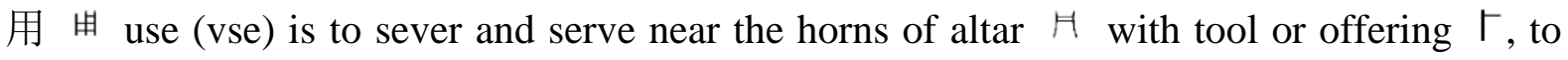
utilize with tool. 禾 grains on altar 周 are dense (seedN) 稠, seeds on altar or second cut. Although servant 佣 is a simplified word invented half century ago, it still matches bible. 傏 servant is 庸简 average worshiper to assist priest in Numbers 3:5-7, Deuteronomy 29:11 and Joshua 9:21-27. If the mediocre is not assigned to dice offering at divine domain, he is indolent 慵. 脯 sausage has use 用, as some priest's meat and grapes are preserved. 哺 to 
nurse has sev to serve. 通 traverse has sever to serve. 捅 poke is for worshiper to open served offering by hand $\neq$.

甫负 pastor prostrates 匍 in worship and casts lot $卜$ ト, when one bird $叉$ sacrifices and the other is released, although $\propto$ can also represent other offerings such as ox. 葡 grape vine prostrates 匍 in vineyard 圃. In John 15:1-5, 傅 Teacher claims Himself “The True Vine”, and teacher of law tears and chars. 輔 靼 to cooperate has co pter, two birds. To cooperate also tears offering. 鋪 is to spread on burnt altar, as in Exodus 38:2 "they overlaid the altar with bronze". 賻 present to bereaved families has wealth 貝 to hand $\Rightarrow$ to priest 甫, as in Exodus 1:15-12:36 "The Israelites did as Moses instructed and asked the Egyptians for articles of silver and gold and for clothing. THE LORD had made the Egyptians favorably disposed toward the people, and they gave them what they asked for" after Pharaoh murdered Hebrew boys. So victims received the gifts. To interlink in biblical etymology, 甫 minister, 傅 master, 敷 plaster, 缚/捕 arrest, 搏 struggle, 匍 prostrate and 簿 registers have sert to serve. 甫 priest, 賻 present and 鋪/敷数 spread have serp to separate offering.

Priest spreads ointment on the anointed or infected after offering $\psi$, and plasters wall with clay. If "the mildew has not spread after the house has been plastered, he shall pronounce the house clean". "He shall purify the house with the bird's blood, the fresh water, the live bird, the cedar wood, the hyssop and the scarlet yarn. Then he is to release the live bird" to escape 逋 after scraping the wall. 補分迪 renovation and repair have ver of sever and aveon of avian.

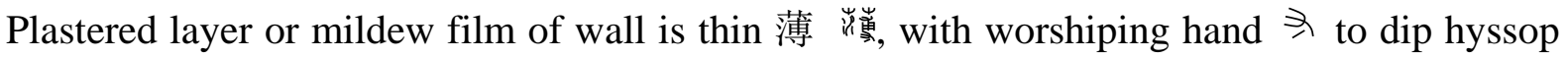
$\psi \psi$ in water and blood i i of sacrificed ornith $\psi$ near altar $\models$ in divination $\vdash$. 蒲莎湈 papyrus or reed has grass $\psi \psi$, 识 Nile river and priest 甫 Moses, as in Exodus 2:2-3 “she got a papyrus basket for him and coated it with tar and pitch. Then she placed the child in it and put it among the reeds along the bank of the Nile".

博 博 erudite is priest 甫 whose hand $尹$ offered at altar 苖 and held staff $†$. In Acts 7:22, "Moses was educated in all the wisdom of the Egyptians and was powerful in speech and action." 誦 to recite is related to dice and sever. 笽 is firstfruit basket, as in Deuteronomy 26:1-11 "take some of the firstfruits of all that you produce from the soil of the land THE LORD your GOD is giving you and put them in a basket." "The priest shall take the basket from your hands and set it down in front of the altar". 黼 was ornament woven in worshiper's garment. 俑 carved puppet has golden calf. 磅礴, ample and magnificent, has water ii at side of rock 石 with Moses' offerings $\psi * \psi$ at altar $月$.

勇 brave and courageous is sacrifice, including the affix 臽角 with sacrificed taurus, avian, ram or grain offering c on altar $月$. 急 urge is bilingually related to courage 勇. 痛㗈 pain shares identical affix with bravery and courage 勇, as in Isaiah 53:5 and 1 Peter 2:24 “by His wounds we are healed", although Thomas had to be convinced by the nailed hands of Lamb of GOD. In John 20:25-29, "Unless I see the nail marks in His Hands and put my finger where the nails were, and put my hand into His Side, I will not believe it", but "blessed are those who have not seen and yet have believed" without physical miracles by physical eyes. Hero includes those wounded in sacrifice for the public interest of others, with Jesus Christ as the model. Love is not self-seeking in 1 Corinthians 13:5. Paul boasted for his 
sufferings in 2 Corinthians 11:17-33. "I also dare to boast about". "I have worked much harder, been in prison more frequently, been flogged more severely, and been exposed to death again and again". "I have been constantly on the move. I have been in danger from rivers, in danger from bandits, in danger from my own countrymen, in danger from Gentiles; in danger in the city, in danger in the country, in danger at sea; and in danger from false brothers. I have labored and toiled and have often gone without sleep; I have known hunger and thirst and have been gone without food; I have been cold and naked. Besides everything else, I face daily the pressure of my concern for all the churches.” 痛㗈 is also pain of slaughtered $\Rightarrow$ flock, herd or birds cut or offered in pair. 鳙 carp has par. 墉 rampart has part.

蛹 larva has altar H, and pupa has split hoof as offering. 蛹 cocoon of silkworm symbolizes body cloth and sacrifice. In Matthew 27:59, Mark 15:46, Luke 23:53 and John 19:40, Joseph wrapped The Body of Son in a linen cloth. Soldiers divided His clothes, and disciples must put on new clothing. Larva's shell also symbolizes ark. 蛹 larva has lav of liquid flood. It links to avian raven and brave dove, as after metamorphosis butterfly will come out of pupa to step away and fly like a dove with wings into sky to symbolize spiritual transfiguration. Butterfly is in the order of Lepidoptera, with ptera as wings. Water reflects sunlight 粼, whose 舛姏 are two steps, pu pa. The scales of butterfly and fish reflect light. Flock leaped 踊 before being offered by Noah at flooded place 埔 or riverside 浦. 涌滔 to erupt has pter as raven's wings, as "all the springs of the great deep burst forth".

GOD could hypnotize the creatures of ark. There are biblical examples of men put into deep sleep. In Genesis 2:21, "GOD caused the man to fall into a deep sleep; and while he was sleeping, he took one of the man's rib and closed up the place with flesh." In Genesis 28:11-22, "he put it under his head and lay down to sleep. He had a dream in which he saw a stairway". "Early the next morning Jacob took the stone he had placed under his head and set it up as a pillar". Caterpillar has many dactyl parts, but hibernates, eats leave and resembles stair pillar step by step to leave the earth through paved avenue 角, which originally represents avenue to altar during travel. 桶 bucket and barrel cut in parallel. Related to use 用 and worth, 甩 to throw is to throw ornith (bird) crop at altar in worship. In Leviticus 1:16, "He is to remove the crop with its contents and throw it to the east side of the altar." 扔 to

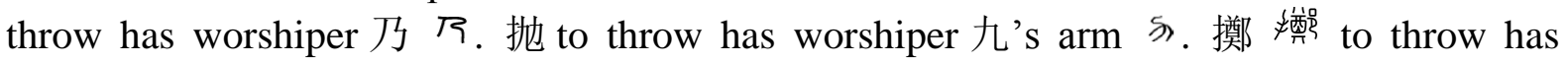
worshiper 2 at altar $\square$ with divided offering $/ 1$.

\subsection{Color and Shape}

\subsubsection{Purple}

紫 purple is perplex and plural, as it has people $t$ with tricolor cords 宗䒺系 of purple, read and blue, and is read and blue mixed together. 紫 purple has this (此) linage (系) from Adam, Abraham, Judah, David, Joseph to Jesus in Matthew 1 and Luke 3, when in Mark 15:17-20 and John 19:2 “They clothed Him in a purple robe”. 雜, perplex, complex, complicate or commingle, mixes and twists red, blue and purple threads in clothing 卒 $\widehat{x}$ represented originally by animal leather ( $\mathrm{Du}, 2019 \mathrm{c}, \mathrm{Xu}, 100-121$ A.D.). Its plant 木 is linen, and 隹 is cherubim woven in priestly garment. 碎 fragment is to garment, although its additional 
etymology is stone 石 and animal 卒. When unclean animal like lizard “falls into a clay pot, everything in it will be unclean, and you must break the pot" in Leviticus 11:33-35. 萃 is to extract dyes of clothes 卒 from plants $\Psi+$. 粹 is rice's grain after breaking its cover. 悴 is broken heart to be depressed, and to depress has to dress people, because in Genesis 3:21-24 "GOD made garments of skin for Adam and his wife and clothed them" before their exile and hard labor, so that 瘁 is exhausted from overwork. 淬/焠 quench is to pour water to burnt offering, also meaning to put hot metal into liquid to quench after forging metals, so that quench has liquid.

\subsubsection{Blue}

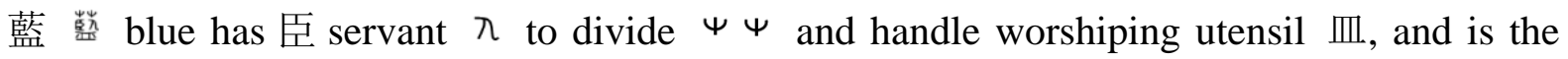
color of tabernacle's covering and robe of priests. 監 supervision is in blue 藍, as priests are supervisors. In Exodus 28:31-35, "Make the robe of the ephod entirely of blue cloth". 靛 indigo has the forbidden tabernacle $\rightarrow$ to 4 go into (endo), as in Numbers 4:6-12 "when the camp is to move", "they are to spread a blue cloth" over altar, ark, table and lampstand, with all the articles wrapped in blue cloth. To include and seclude is blue, as the utensils are secluded in blue cloth.

\subsubsection{Silver}

銀 silver is to sever and serve. 喰 has 食 food severed 走 around altar. Service is a set of dishes to serve. The etymology of silver includes silver cup in food sack in Genesis 44:1-12, and silver cup 银杯 has the affixes of no diet 不食. “Fill the men's sacks with as much food as they can carry, and put each man's silver in the mouth of his sack. Then put my cup, the silver one, in the mouth of the youngest one's sack, along with the silver for his grain." Cup and mug have c/m as liquid and pu/gu to go. Where liquid goes is cup or mug. In etymology, 杯 cup is related to recuperation of cupbearer in occupation, and has either no (不) wood (木) to curse, or bird under sky 不 (Xu, 100-121 A.D.), since in Genesis 40 "Pharaoh was angry with his two officials, the chief cupbearer and the chief baker, and put them in custody". Joseph interpreted cupbearer's dream, "Within three days Pharaoh will lift up your head and restore you to your position, and you will put Pharaoh's cup in his hand, just as you used to do when you were his cupbearer." However, for baker "Within three days Pharaoh will lift off your head and impale your body on a pole. And the birds will eat away your flesh." "He restored the chief cupbearer to his position, so that he once again put the cup into Pharaoh's hand - but he impaled the chief baker, just as Joseph had said to them in his interpretation".

\subsubsection{Gray}

灰 gray is the color of ash and garbage. 赤 氺 red and 赫 reddish brown are two colors of fire from burnt offering: red has worshiper (er) $大$ and fire $心$, and reddish brown has brn of burn 火 and wor shid er of worshiper 者 $九$, although additional etymology of red, scarlet and other colors and their multilingual mutual match in biblical etymology have been presented (Du, 2019c and 2020b/e). 


\subsubsection{Etymology of Shape}

狀 shape includes the shape of cut pieces $\hbar$ (片 resembles one side of sheep) as priest's share.

Typical examples of biblical shape are column and globe. In exodus 40:38, "Whenever the people saw the pillar of cloud standing at the entrance to the tent, they all stood and worshiped, each at the entrance to his tent." Column or pillar 柱 has 主 LORD arriving in pillar of cloud, and column has colu of cloud. Pillar's double 1 (11, co 1) is cloud $\bar{\nabla}$, and piar/pier is pedestrian in piety, although in some words singular 1 can also represent cloud. This divine location 于 $\bar{\zeta}$ has the double lines 二 as cloud 云 $\overline{\bar{\sigma}}$, although location could also be related to coal at altar. In Exodus 13:21, "By day THE LORD went ahead of them in a pillar of cloud to guide them on their way and by night in a pillar of fire to give them light, so that they could travel by day or night."

片 $K$ piece and pie are side of flock cut for offering. 塊 piece has ghost 鬼 and burnt altar 田. In Judges 13 when an angel visited, Manoah took a young goat, together with the grain offering, and sacrificed it on a rock. This involved cutting offering to pieces. 版 tablet has calf $h$ and against 反, as the tablets of law stone were broken by Moses, when people worshiped golden calf in rebellion. It is forbidden for most people to touch Holy Tent \ulcorner with hand $₹$. This is one etymology of 反反 negative or anti, into Tent. While negative is ga (go) en (in) Tent, or not (ne) ga (go) in, its antonym, 正 $\forall$ positive, is to $\forall$ poise in front of holy room $\square$, or stand before altar $\square$. In Numbers 1:51, 4:15 and 18:3 "whenever the tabernacle is to be set up, the Levites shall do it. Anyone else who goes near it shall be put to death". "Kohathites are to come to do the carrying. But they must not touch the holy things". This affix gives rise to antagonism, antagonize, antarctic, antibiotic, antibody, anticlimax, anticyclone, antidote, antifreeze, antiknock, antilogarithm, antipathy, antipodes, antiseptic, antitoxin, and antonym. 反 is also in return 返, as some priests are allowed to return into Tent of Meeting and then return to their people. Ante is before and in front, as the altar of bronze network is in front of Tent. This gives rise to antecedent, antechamber, antedate, antediluvian, antemeridiem, antenatal, antenuptial, anterior, anteroom, anthropology, anticipate, antiquary, antiquated, antique, and antiquity. Antelope, antenna and antler could resemble horns of ox or altar as these horns are in front of ark or Tent.

\subsubsection{The Affix of 球 Global Plea 求}

球 globe has gold and the affix of robe 装, and sphere has to dress ephod, as pomegranate is an attached globular accessory on robe to access tabernacle. In Exodus 28:33-35, "Make pomegranates of blue, purple and scarlet yarn around the hem of the robe, with gold bells between them." These round pomegranates are under the robe. "The sound of the bells will be heard when he enters the Holy Place before THE LORD and when he comes out, so that he will not die." Thus, round links to sound, robe links to obey, and 鈴鐺 bell has appropriate 当 demand 令 会. 鉦, percussion instrument in the shape of bell, has to step $\forall$ to holy room. Goblet has inverted bell, and ball is next to bell, as "the bells and pomegranates alternated around the hem of the robe to be worn". Pomegranate is garnish as ornament, and embellishment is the hem of priest's robe. 
In typical bilingual match, 球 globe has beg 求, the affix of coat 装 etymologically originated from furry leather 求 录, and beg sounds bag, as bag was initially made from leather . In Genesis 21:14-20, “Abraham took some food and a skin of water". can also represent tricolor fibers. 求 pursuit has suite. In Leviticus 1:6 "He is to skin the burnt offering and cut it to pieces", so that 求 plea is to peel 剥. Appeal is to peel ox $\forall$ to plea to GOD. Pledge is to peel to plea. Please plea to GOD! Please is to peel leather and slice offering to pieces pleasantly 悦, with division 八 at altar $甘$ in elation. 銳 acute is to cut八 calf $\forall$ by hand $₹$ near altar $\square$. Obtuse is to obstruct cut. Sue, suede, pursue, pursuit, suppliant and succour/rescue 救 have detached leather 际 in supplication.

One interpretation of rescue has cover to be torn, as in 2 Kings 19:1-19:36 "When King Hezekiah heard this, he tore his clothes and put on sackcloth and went into the temple of LORD." "Now, O LORD our GOD, deliver us from his hand, so that all kingdoms on earth may know that YOU ALONE, O LORD, ARE GOD." "Sennacherib king of Assyria broke camp and withdrew." Tuck cuts and peeled leather forms pleat, although pleat 摺/褶 has feather 羽 because cherubim are woven in curtains and the front curtain of tabernacle is folded (Moses, 2nd millennium B.C.b.).

求's additional interpretation is Noah's olive leaf. In Genesis 8-9, “Noah opened the window he had made in the ark and sent out a raven."'Then he sent out a dove". "He reached out his hand and took the dove and brought it back to himself in the ark. When the dove returned to him in the evening, there in its beak was a freshly plucked olive leaf! Then Noah knew that the water had receded from the earth.”救 㪝 save has olive leaf by hand 录 and hand ₹ with plucked lucky olive $\vdash$. Save is either man or water with ave, raven and dove, as ave is bird in English and Spanish related languages.

球 ball has jade玉 and clothes 求, as priest's robe is full of precious stones-“two onyx stones” and "four rows of precious stones on it. In the first row there shall be a ruby, a topaz and a beryl; in the second row a turquoise, a sapphire and an emerald; in the third row a jacinth, an agate and an amethyst; in the fourth row a chrysolite, an onyx and a jasper”. 璧 壁 jade has bull $*$ under cloud $\overline{\bar{\sigma}}$ and slaughtered near altar $\square$ and tabernacle $P$ by priest. 瑜 gems are worn by high priest on Ephod throughout Exodus 28:9-39:14. Four rows of gems on

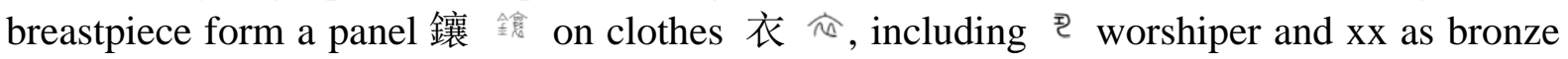
network of burnt altar 口.

\subsubsection{Other Affixes Related to Furry Leather}

fur or hair is also represented by additional affixes. 毛 $₹$ is fur or hair. Leather is related to

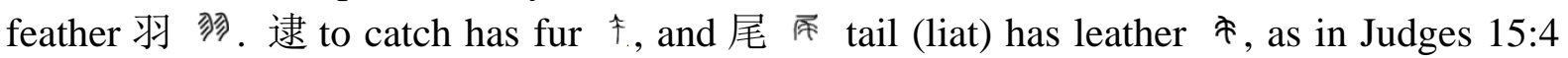
“he went out and caught three hundred foxes and tied them tail to tail”. 徽徽 insignia or badge is fastened 系 by hand 攴, when the emblem is near hair 个. In Exodus 28:36-40:31, "Make a plate of pure gold and engrave on it as a seal: HOLY TO THE LORD. Fasten a blue cord to it to attach it to the turban; it is to be on the front of the turban. It will be on Aaron's forehead". 徵 徽 enlist has priests or dedicated Nazirites, as “priests must not shave their heads" in Leviticus 21:5 and "During the entire period of his vow of separation no razor may 
be used on his head." When separation is over, "the Nazirite must shave off the hair that he dedicated. He is to take the hair and put it in the fire that is under the sacrifice of the fellowship offering”. Thus, 一 of $\leftleftarrows$ means either no or to remove hair $\leftleftarrows$. 徵 徵 also means hint. 微微 tiny is the shaven hair. Rotating h to y turns 徵 hint to tiny 微, when Nazirite $\vec{x}$ of dedication 聖 is turned to secular person $\mathbb{R}$.

In Genesis 27:6-45, Rebekah "covered his hands and the smooth part of his neck with the goatskins", so that Isaac could not recognize Jacob from Esau and blessed Jacob instead. "Esau was angry with Jacob" and threatened to kill. Rebekah had to tell Jacob, "Go at once to my brother Laban in Haran. Stay with him until your brother's anger calms down.” The goat fur of the furtive man brought fury to his furry twin.

\subsubsection{Pledge}

盟 oath has worshiping utensil 皿, burnt altar 日 (alternatively written as 圆 in ancient versions), and offering $\mathbb{D}(\mathrm{Du}, 2020 \mathrm{c})$, as one of the numerous etymological surprises throughout languages. Oath is related to heat (hoat) of burnt offering and theo (thao) of theology. Pledge has the ledge (一) of burnt altar $\square$, although its alternative etymology is to peel offering's leather, as mentioned in the preceding section about the affix of global plea. 誓篅 pledge has worshiper's hand $*$ to peel leather $\vec{k}$, skin 皮际. 折 fold is to fold leather of flock or herd or fur clothes by hand. 哲 knowledge is to know how to skin leather and work at ledge of altar 口, because true knowledge is to pledge to love GOD. In Proverbs 1:7 and 9:10, "The fear of THE LORD is the beginning of knowledge". "The fear of THE LORD is the beginning of wisdom, and knowledge of THE HOLY ONE is understanding."

誓 oath is also to cut offering with hatchet 斧 by hand $¥$ near altar 口. 祈 赥 pray has axe 斧 to cut offering to parts, as Abraham and priests cut offering in pair (par) and to parts. In Genesis 15:10-18 "Abram brought all these to him, cut them in two". "On that day THE LORD made a covenant with Abram" in oath 誓. This oath led to departure of Abraham's descendants four centuries later from Egypt to Canaan, after 逝 departure of their murdered sons.

In additional etymology, pledge is to peel edge of foreskin. 約 covenant is ante cover, fore cover of skin to be cut (Du, 2019c). In Genesis 17, “This is MY covenant with you and your descendants after you, the covenant you are to keep: Every male among you shall be circumcised."

\subsubsection{Circle}

Letter 1 represents line, letter $\mathrm{C} / \mathrm{c}$ represents curve, and letter O/o represents circle or similar shape. Oval has $\mathrm{O}$ to resemble egg. Curve could be the curvature between curtains. In Exodus 26:9 and 27:18, "Fold the sixth curtain double at the front of the tent". 弧 curve has bow (Ur) 弓, and bow's string has ring. In additional etymology, 曲 戈玤 curve has crop culture such as cereal or rice 奉, which curves after harvest. Culture has curl and curue of curve. In bilingual match, 禮 courtesy has curve 曲, and also means to worship GOD in ceremony. 禮 ceremony has cereal 㭋. 醴 rice wine is brewed from culture. Mill is round to grind grain for crop to be ground. Curve is related to ring, and grain has ring, as a ring $\bigcirc$ binds 束 $_{\text {a }}$ 


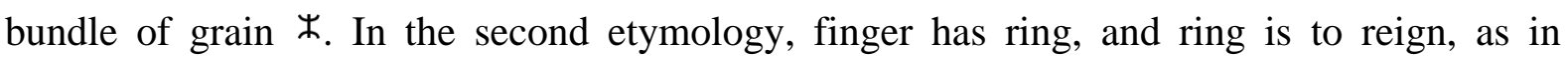
Genesis 41:41-42 "“I hereby put you in charge of the whole land of Egypt." Then Pharaoh took his signet ring from his finger and put it on Joseph's finger." In Esther 3:10-12 and 8:2-10 "king took off his signet ring" and "no document written in the king's name and sealed with his ring can be revoked." Exodus 35:22 and Numbers 31:50 describe "jewelry of all kinds: brooches, earrings, rings and ornaments". 戒 ring is sign and has fingers $k$ a of authorized man $\frac{\hbar}{x}$. In the third etymology, ring is related to origin and region, and round is related to ground, as in Isaiah 40:22 "HE sits enthroned above the circle of the earth". In Revelations 6:14 and Hebrews 1:12, "The sky receded like a scroll, rolling". Thus, bible was consistent with science, before Greek philosophers proposed round earth proven by Ferdinand Magellan and his colleagues around 1522.

Circular circle, circumvention, circumstance, and circus of Latin and Greek are related to curve and culture, but their affix circ is also related to script. In addition, circle, cyclic, cycle and cylinder are related to scroll and cloth, as scroll is on parchment and the etymology of clothes is leather, so that cloth is related to scroll, scroll has roll 卷, and rolled scroll is in the shape of cylinder. In 2 Kings 2:8 "Elijah took his cloak, rolled it". Pomelo has loop, peeled apple skin forms loop, and book and scroll are related to loop. 環/圖/圈 circle has clerc of clerk and clothes 衣, as in Isaiah 34:4 and Exodus 28:23-28 "Make two gold rings for it and fasten them to two corners of the breastpiece. Fasten the two gold chains to the rings at the corners of the breastpiece," "attaching them to the shoulder pieces of the ephod at the front". "Make two gold rings and attach them to the other two corners of the breastpiece on the inside edge next to the ephod. Make two more gold rings and attach them to the bottom of the shoulder pieces on the front of the ephod". 旋 蝑 helix has 岁 Elisha and 正 Elijah who rose up 入. In 2 Kings 2:1-12, "LORD was about to take Elijah up to heaven in a whirlwind", and twine has two men and wind to wind.

弗弗, not on earth, has the helical air $弓$ and ascent , which also resembles cloud pillar. 沸 to boil is water vapor $弓$ to ascend $川$ as mobile liquid. 拂 is to brush something from one place to another place, such as wind to brush dust away from earth. 费 expense is to spend already so that the wealth 财 is not on earth 弗. To spend is for expense to step away, related to speed and pedestrian in etymology. In apparent bilingual match, 费 to consume is related to assume and seem 佛. 仿佛, to look alike, look as if, and seem, has 方 岁 Elisha and Elijah's ascent to heaven $川$ in helical wind 弓, as “"You have asked a difficult thing," Elijah said, "yet if you see me when I am taken from you, it will be yours - otherwise, it will not." As they were walking along and talking together, suddenly a chariot of fire and horses of fire appeared and separated the two of them, and Elijah went up to heaven in a whirlwind. Elisha saw this and cried out, "My father! My father! The chariots and horsemen of Israel!" And Elisha saw him no more." Seem is see me, "if you see me when I am taken". Accordingly, 佛 is someone (人) not on earth (弗) anymore, and was later borrowed to refer to Buddha, a historical wise man who left the earth after claiming heavenly revelation without self claim as divinity. 


\subsubsection{Flat and Cubic}

平 flat is flat altar for divided 八 offering. The rectangle is the shape of tabernacle, ark, altars and table. 方乔 cube is from cubic, as measured with and rabbis barbecue and butcher cut offering. In Exodus 25-38, ark is "two and a half cubits long, a cubit and a half wide, and a cubit and a half high". Burnt altar is "three cubits high; it is to be square, five cubits long and five cubits wide". 菱 diamond has media 八 to donated meat. 點 dot or spot, conifer and corner have been presented ( $\mathrm{Du}, 2020 \mathrm{~b} / \mathrm{c}$ ). Conic cone is from conifer, and 軸 axis is to exit from 由.

\subsubsection{Angle Versus Long Line}

Not go in straight length is ong or gon as the affix of angle in triangle, polygon, pentagon and hexagon, and angle is an leng, not long in length, as direction changes along length. 曲 song has ong of angle, curve 曲, and sound is related to round. 寬 wide is the width between two (di) steps (w+vowel) $\gtreqless$, and high is for human to go (gi) from one altitude to another altitude. Thus, wide is related to wade, and high is related to hike. 高畣高 altitude has altar $\square$ at a high building.

线 line is linen and has 系, the affix of textile with yarn of three colors $\exists$. Line is 1 in E, line in three colored yarn $\exists$ in direct morphology. In Exodus 27:16, "For the entrance to the courtyard, provide a curtain twenty cubits long, of blue, purple and scarlet yarn and finely twisted linen". As linen lines are woven into the three colored yarns, 麻 linen has Tent of Meeting $\ulcorner$ as Levite priests wear fine linen to worship. In Ezekiel 44:17, "When they enter the gates of the inner court, they are to wear linen clothes".

\subsubsection{Center, Edge and Side}

The etymology of center as censer and incense altar has been presented (Du, 2020c). Edge cannot go (ge) further. 旁 side is where worshiper Infra could be beneath fire, and gives rise to infrared. 邊 fringe is to ignite fire on one side of burnt altar. 磅礴 is magnificent water ii near rock 石 of mountain, with cloud, $\alpha$ offering, and a plant affix $\psi \psi$ to indicate olive leaf. 滂 heavy rain was revealed by GOD 帝 to the running Elijah Jezreel. THE POWER OF THE LORD came on Elijah and, tucking his cloak into his belt, he ran ahead of Ahab all the way to Jezreel". 谤 slander has land aside 旁, as in Numbers 12:1-8 "Miriam and Aaron began to talk against Moses because of his Cushite wife, for he had married a Cushite." Cush is outside land and the Cushite was not insider.

\subsection{Sound}

\subsubsection{Sound And Voice's Etymology}

Sound, Soul and Son are related in etymology. In Matthew 2:12-3:17, "He saw THE SPIRIT OF GOD descending like a dove and lighting on Him. And A VOICE from heaven said, "This is MY Son, Whom I love; with Him I AM well pleased."' In John 1:29, "Look, The Lamb of GOD, Who takes away the sin of the world!” Thus, 音焉 sound has Son 童, cloud $\bar{v}$ and $¥$ Lamb on symbolic altar 日 as the first etymology. 童 Son is SOUND 音 on ground 
土. Sound, sonic, sonar, ultrasonic, infrasonic, sonication, resonance, consonance and dissonance all have son. Sound 音, Son 童, Child 童, collide 撞 and clock 鐘 are bilingual match to Son's $12 x 2$ earthly branch hours clockwise (Du, 2020d).

Reflecting the relationship between cloud and sound, 丞 言/詞 vocabulary has cloud (cloub) and bula of nebula $\boldsymbol{\nabla}$. Vocal's affix voc is in voice, advocate and revoke. Civil civilization is

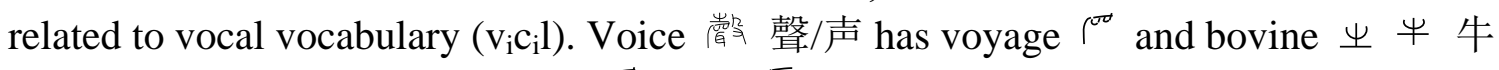
(cow, cov, ox), vocal is to relocate $\Gamma^{\sigma}$ from $(\ulcorner$ ) one location $(\nabla)$ to another $(\odot)$, and acoustic is to evacuate oust and co cut, as LORD said to Abraham after foretelling his son's birth 生, "Bring ME a heifer, a goat and a ram...cut them in two" in Genesis 15. "Abram fell into a deep sleep, and a thick and dreadful darkness came over him. Then THE LORD said to him, "know for certain that your descendants will be strangers in a country not their own, and they will be enslaved and mistreated four hundred years. But I will punish the nation they serve as slaves, and afterward they will come out"". "In the fourth generation your descendants will come back". To GOD of all spaces and times, four centuries later was not unknown future. GOD can reverse time and space if necessary. RIGHTEOUS GOD knows in advance the faith and action of people in order to fore call, so that typically to fore call does not mean that

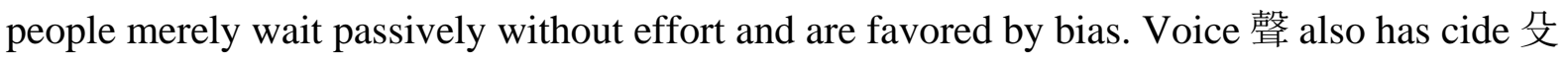
to kill the offered ox, Hebrew boys by Pharaoh, or firstborns of the nation in Passover.

Besides, Abraham listened to VOICE and almost "took the knife to slay his son" to sacrifice in a key test of faith in Genesis 22. 眉 brow is created above eye 目 to remind mobility $巴$, as Adam and Eve left paradise after eating forbidden fruit to open eyes in Genesis 3. The attractive but tempting 媚 Eve as woman 女 was tempted, “when you eat of it your eyes will be opened”. 楣 upper doorframe with blood of lambs has relocation $巴$ around Passover. In beautiful match to dual testaments, 声 Voice is to son and 音 Sound is to Son.

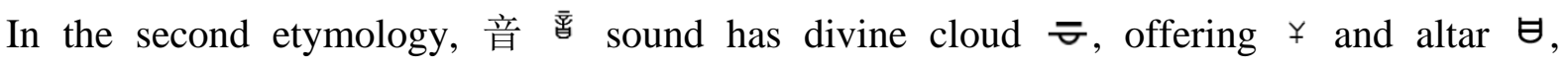
because of divine conversation to Moses. For example in Numbers 7:89 and Exodus 25:31-40:38, "Put the altar in front of the curtain that is before the ark of the Testimony - before the atonement cover that is over the Testimony — where I will meet with you." "Then the cloud covered the Tent of Meeting, and THE GLORY OF THE LORD filled the Tabernacle." "When Moses entered the Tent of Meeting to speak with THE LORD, he heard THE VOICE speaking to him from between the two cherubim above the atonement cover on the ark of the Testimony". This is also the etymology of interpretation. To interpret is inter pter, between wings of cherubim. Thus, 㘓 to interpret has entrance 門 of Tent of Meeting, and 詮 to interpret has the forbidden Tent of Meeting $\triangle$. 荃, aromatic plant, has aroma reminiscent of incense altar in front of atonement cover for plea of recovery in health 痊. In Numbers 16:46 Moses said to Aaron, “Take your censer and put incense in it, along with burning coals from the altar, and hurry to the assembly to make atonement for them. Wrath has come out from THE LORD; the plague has started." Although in parable potter has the right to destroy pot, GOD does not punish people by cancers and extremely cruel tortures - unless bible is misprinted to misuse Word to break ten commandments - and has ceased punishment until final judgement because of law of love from Son of GOD. Human who wants to "be like GOD" to kill and punish others infringes AUTHORITY. Adam lost 
eternal life, because GOD concerned that Adam would be like GOD (Moses, 2nd millennium B.C.a.).

音 Sound has Son 童 also because in John 10:2-17 His sheep can hear His Voice. In addition, sound and son are related in etymology because of 1 Samuel 3:1-18. "In those days THE WORD OF THE LORD was rare; there were not many visions. One night Eli, whose eyes were becoming so weak that he could barely see, was lying down in his usual place. The lamp of GOD had not yet gone out, and Samuel was lying down in the house of THE LORD, where the ark of GOD was. Then THE LORD called Samuel. Samuel answered, "Here I am." And he ran to Eli and said, "Here I am; you called me." But Eli said, "I did not call; go back and lie down." So he went and lay down. Again THE LORD called, "Samuel!" And Samuel got up and went to Eli and said, "Here I am; you called me." "My son," Eli said, "I did not call; go back and lie down." Now Samuel did not yet know THE LORD: THE WORD OF THE LORD had not yet been revealed to him. A third time THE LORD called, "Samuel!" And Samuel got up and went to Eli and said, "Here I am; you called me." Then Eli realized that THE LORD was calling the boy."

\subsubsection{Prison and Religion's Etymology}

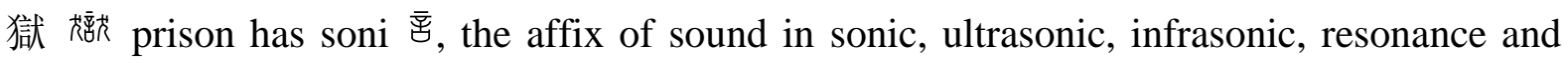
consonance, and two priests $\vec{r} \vec{r}$, one on each side (Moses and Aaron). In the past millenniums, linguists misconsidered that its etymology was two dogs in front of a jail, and such interpretation has to be totally revised to fit biblical etymology: Godly priests. 获 mountain has prison 獄 and apparently refers to Mount Sinai, as GOD issued the law on Sinai mountain and behind the inner curtain of Tent of Meeting, and priests enforced this law. Thus, prison is related to priest, mountain is related to acoustic, sound is related to announce, and curtain is related to detain in detention. From Exodus 19:20 to Deuteronomy 32:46, laws were recorded in about a hundred of pages in the book of law, such as rules of worship, daily activity and festival, marriage, clothing, agriculture, personal and employment relationship, crime and injury, protection and transaction of property, and family and social responsibility. There were even decrees on what types of food were allowed. "THE LORD descended to the top of Mount Sinai and called Moses", and spoke the core Ten Commandments: "I AM THE LORD your GOD". "You shall have no other gods". "You shall not make for yourself an idol in the form of anything". "You shall not bow down to them or worship them". "You shall not misuse THE NAME OF THE LORD your GOD, for THE LORD will not hold anyone guiltless". "Remember the Sabbath day by keeping it holy". "Honor your father and mother". "You shall not murder." "You shall not commit adultery." "You shall not steal." "You shall not give false testimony against your neighbor." "You shall not covert your neighbor's house. You shall not covet your neighbor's wife, or his manservant or maidservant, his ox or donkey, or anything that belongs to your neighbor." Not to covet is a covenant. These laws were very civilized and distinct from those of other regions, showing the divine view. For instance, in the seventh year, servant shall be released for free. "Do not spread false reports." "Do not deny justice". "Have nothing to do with a false charge and do not put an innocent or honest person to death, for I will not acquit the guilty." "Do not accept a bribe". "Do not oppress an alien; you yourselves know how it feels to be aliens, because you were aliens". 
Religion, originated from Latin, has logi (ligio), a legal affix in legitimate, legislature and logic. The etymology of religion is related to legal regional log, the book of law of Israelites when the divine legion migrated from the region of Egypt to Canaan and logged the journey in religious journal catalogs, Exodus, Leviticus, Numbers, Deuteronomy and Joshua. For instance in the logged events of Deuteronomy 1-4 and 17:18-31:26, "I have taught you decrees and laws as THE LORD my GOD commanded me, so that you may follow them in the land you are entering to take possession of it. Observe them carefully". "HE declared to you HIS covenant, the Ten Commandments, which HE commanded you to follow and then wrote them on two stone tablets. And THE LORD directed me at that time to teach you the decrees and laws you are to follow in the land that you are crossing the Jordan to possess" and "to read it all the days of his life so that he may learn to revere THE LORD his GOD and follow carefully all the words of this law and these decrees". "Take this Book of the Law and place it beside the Ark of the covenant of THE LORD your GOD. There it will remain as a witness". The book of law interconnects literal literature, literate, literacy, logical log, region, legion, legal litigation, legitimate, and legislature. Religion is legal code of GOD for regime at any region in reliance. Scripture has priest (priest+cur), and script has Christ (cprist).

In additional etymology, religion is to lit on grill to grill on, as in Leviticus 1-7 the offering to THE LORD is typically a burnt offering on the grill of burnt altar termed copper grating. 教 鼓 religion has this bronze grill $\Varangle$. In Exodus 27:1-38:7, “They made a grating for the altar, a bronze network, to be under its ledge, halfway up the altar. They cast bronze rings to hold the poles for the four corners of the bronze grating.” 教 歧 also means to teach, as the initial education was to learn how to cut and char cattle on grill of burnt altar, so that religion has leorn to learn to grill $(\mathrm{Du}, 2019 \mathrm{a} / \mathrm{b})$. Maya language has plenty of copper grating although Mayan religious practice is different. Such phenomena of biblical match are obviously consistent with divine creation of native American languages as a major branch of the several ancient linguistic systems.

\subsubsection{Constitution and Law's Etymology}

憲 constitution has tent of Abraham $\vdash$, great tree of Mamre 丰, 四 burnt altar with divided offering east to this tree and tent, and eye 目 and 心 heart of Abraham. The constitution is the covenant of GOD with Abraham. Covenant is ante cover, fore cover skin, to be circumcised 割 in Genesis 17. "You are to undergo circumcision, and it will be the sign of the covenant between ME and you". In new testament "circumcision is circumcision of the heart"心 in Romans 2:29.

Constitution is into stitched tent for tenets, also because of the majority of potent tenets stipulated to Moses in Tent of Meeting. In Leviticus 1:1, "LORD called to Moses and spoke to him from the Tent of Meeting". Tricolor yarn and linen were stitched and knitted into curtains to construct and constitute this divine institute. Intent and intention are in tent and into tent, intuition is instant and tentative, and tent contains content to constitute tent. With $\mathrm{u}$ $\mathrm{n}$ rotation, tute is tent.

Consistent with the etymology of law related to walk in Exodus (Du, 2019b), 法憘 law has red sea $\lambda$, altar $\delta$, migrating human $\downarrow$, lamb $\theta$ and hand with staff $₹$. Law also has 
Jesus with $\Varangle$ water, $\sigma$ altar that indicates divinity, baptized human $\downarrow, \gamma$ Lamb, and hand

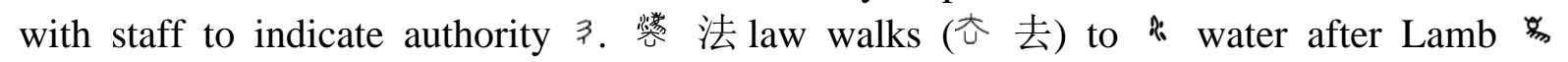
merged with temple $>$ as High Priest. To baptize is basic ritual in new testament, and Lamb of GOD has renewed the law in order to uphold law. In Mark 12:29-31, "Hear, O Israel, THE LORD our GOD, THE LORD is ONE. Love THE LORD your GOD with all your heart and with all your soul and with all your mind and with all your strength. The second is this: 'Love your neighbor as yourself." In John 15:17, “This is My command: Love each other". These are key laws throughout old and new testaments. In a parable to understand the relationship between old and new testaments, marriage law at ancient time allowed multiple wives and marriage between close relatives, but modern marriage law in most of the world bans these, although both laws require marriage between male and female. The prohibition of multiple wives strengthens the law.

One additional etymology of law 法 is water $\lambda$ (wa) to go away 去 (1), and human blood to remove 去 (1), as GOD established the everlasting covenant of not shedding human blood as a major law for all creatures on earth, immediately after flood in Genesis 9. Logic and logos in Latin and Greek also have flood and blood (lo) to go. x太 with water, as violence (no love) triggered great flood and divine reiteration to emphasize no shedding of human blood. From Etymological view, Noah's flood absolutely occurred (Du, $2019 \mathrm{~b} / \mathrm{c}$ ), although languages have been divinely confused to hide this main secret of civilization, multilingual mutual match in biblical etymology, until now.

Court is courtyard, where priests judge at the field of fidelity, and courtly and courteously worship as polite policy. 訴新席訟 lawsuit is to split八 calf and is law between two persons. To prosecute is to cut to separate offering. Tuition is to split offering into two. Litigation has ligit, a legal affix in legitimate and legislature. It is related to literature, the book of law. Lawsuit's suit is iust, just. In other words, lawsuit is law and just. Lawsuit also has twis of twice and witness, because at least two witnesses are required for biblical lawsuit. In Deuteronomy 17:6 and Numbers 35:30, "On the testimony of two or three witnesses a man shall be put to death, but no one shall be put to death on the testimony of only one witness." Thus, witness links two, just is tuis, and justice has twice. Another etymology for justice is two sections in final judgement (see "Flood and Blood"). According to Christ's law, we must put on spiritual suite to love in faith and action.

Witness is also in investigation, since to investigate is to go (ig/ga) to vitnes (witness), although to invest is to set vineyard. To serve as one in Vine is to invest. In John 15:1-8, Jesus Christ claims that "I Am The Vine; you are the branches". 迹 vestige is the leftover after severing offering 八 by worshiper 大, and has too亦炎 as it is a section too. 弯恋 to play chess is between two people by hands $F^{7}$, and chess has second human ( $\sec \mathrm{h}$ ), cession and section ハ. Chessboard has divided sections \#. 奕樊 big and bright has $\Uparrow$ worshiper standing (ig) to dissect offering 八 to two (bi, 亦) near fire 火 小.

In alternative etymology, 偵 investigation is to wife's virtue 貞齿 by casting lot $卜$ at altar with grain offering $r$, regarding embryo $\underline{\Xi}$ and abdomen and legs $\boldsymbol{W}$ of pregnant woman. In Numbers 5:11-28, "If a man's wife goes astray and is unfaithful to him by sleeping with 
another man," priest should "take a handful of the grain offering as a memorial offering and burn it on the altar" and "have the woman drink the water. If she has defiled herself and been unfaithful", "her abdomen will swell and her thigh waste away." 偵 investigation is also related to invest with the affix of wealth 貝, as civic investigation often involves properties. 淫 滔 lewd has liquid water i", priest's hand $\sigma$ and the woman $?$ with - to mark her abdomen or leg.

In Exodus 22:1-9, "If a man steals an ox or a sheep and slaughters it or sells it, he must pay back five head of cattle for the ox and four sheep for the sheep." "If the stolen animal is found alive in his possession - whether ox or donkey or sheep — he must pay back double." Thus, pay back, 赔, is related to double 倍, whose original etymology is to dissect offering 剖 in biblical department 部. "If a man gives his neighbor sliver or goods for safekeeping and they are stolen", the thief "must pay back double." For dispute, "one whom the judges declare guilty must pay back double". For the parole, priests cut flock to parts.

To verify has jury (ivry), and trial is altar (altir). Jurisdiction, jurisprudence, jurist and jury are related to rival, vary, various and vice versa, more than one, due to "the testimony of two or three witnesses" as jury. Jury and rivalry are surprisingly related to ivory, as ivory 牙 has $€$ and $\exists$ as two people ( $\mathrm{Du}, 2019 \mathrm{~b}$ ). Injury is judged in jury, and perjury in prejudice perplexes jury. 傷 injury is not (in, 一勿) to offer at altar 日 east to tent $ᄉ$, as in Leviticus 22:17-25 "Do not offer to THE LORD the blind, the injured or the maimed, or anything with warts or festering or running sores." "Do not place any of these on the altar as an offering". 傷 injury is also to injure junior by circumcision, foreskin not (一勿) kept near $\pi$ Abraham's tent $ᄉ$, as the ancient version of $\boxminus$ was sometimes drawn as $\odot$. Wound is to unwind round foreskin.

押 custody has 甲 $\uparrow$, to obstruct (一) body out of ( $(1)$ a place $\cap$. It also means mortgage. Mortgage has gage (一) as an affix of against or oppose (Du, 2019c), and is against moving (l) the mortgaged item from a place $\cap$, although gage can also mean two steps together. To engage is two steps together in, or not to oppose each other. 圍 scope has two $\left(\operatorname{seco}_{n} d\right)$ steps (pedes). In etymological correlation, pawn is na paw, no footsteps, as pa is step and wa is to walk by step. 拘 arrest has altar 口 and worshiper, as arrest is associated with high priest, who sentenced Jesus. To restrain is arrest in. In etymology, 拘 detention is bilingually related to sentence 句. Worship and verdict near altar and Tent of Meeting interpret why sentence means either a sentence formed by words or legal verdict.

\subsubsection{Hero and Shore's Etymology}

An excellent word riddle for two opposing steps is hero 傑 谋, including human $\pi$, against as represented by two opposing steps $₹ \neq$, and tree of intelligence $\boldsymbol{*}$ 木 of Eden. 此跃 here has step $\mathbb{E}$ of human $\pi$, as where he steps is here. There has step too. 舞 choreograph

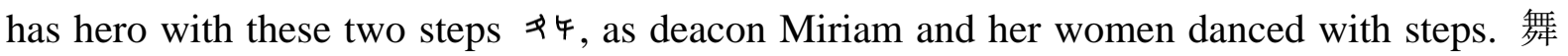
dance has an (無 no) end (stop) as dancer moves steps (Du, 2019b). 違 opposition has these two steps 萍安. Human against the forbidden tree to resist desire and temptation is hero. To prohibit is hero. Paul encourages mankind to overcome flesh to perform every good deed. 
Heroin must be opposed too. The two opposing steps are related to hetero and heresy in etymology.

In surprising etymology related to hero's two steps, 登 chair has rhia, two steps $\boldsymbol{\Psi} \Psi$. As hero has steps to move, the Greek-derived affixes rhea and rheo are to flow, in rheostat, diarrhea, rheum, seborrhea, hemorrhoids, gonorrhea and amenorrhoea, and heir has stepchild.

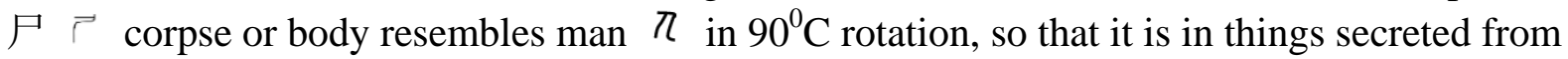
body, such as urea and urine 尿, whose ancient version has man and fluid rheo. Diarrhea has to flow, endocrine is internal flow, and crine of autocrine and paracrine is related to rheo and rhino.

罌, a type of urn $\bar{\Xi}$, is full of wealth 貝 in container 缶. It also means opium and source of heroin, hinting that to pursue after money for opium is toxic. In Mathew 6:24 and Luke 16:13, Jesus claims that "You cannot serve both GOD and money". However, this plant's heroin also has hero, as the treasure in jar also symbolizes Jesus, 嬰 Baby of GOD. In 2 Corinthians $4: 7$, "But we have this treasure in jars of clay to show that this all-surpassing power is from GOD and not from us". Heroin can cause hallucination, as Jesus confused so many people that they thought that "He is possessed by Beelzebub! By the prince of demons He is driving out demons" and that apostles Paul and Peter were crazy. In Mark 3:22, Matthew 12:24-27, Luke 11:15-19 and Acts 26:24, "You are out of your mind, Paul!" he shouted. "Your great learning is driving you insane." 癫狂 insane has true 真 King 王, and hallucination links to hallow.

The other translation of hero 英荧 has two trees or divided offering $+\psi$, altar $H$ and worshiper $\pi$, as anyone touching tree of life first by listening to GOD can reach tree of intelligence and still live forever, but not the other way around. Dividing burnt offering is divine worship by Moses, and holy ground opposed steps, as in Exodus 3:1-17 "Do not come any closer," GOD said. "Take off your scandals, for the place where you are standing is holy ground." Thus, hiero is hetero (more than one) and divine in hieroglyph and hierarchy. Because here, hero, heresy, choreograph and hieroglyph are Greek and Latin words in many languages, these languages must match bible in etymology.

濱滥 shore has hero as step 凶 near Tent of Meeting $\dot{\text { m }}$ around horrible Red Sea that covered horsemen ii. It also has the affix of wealth 貝 as "Israelites did as Moses instructed and asked the Egyptians for articles of silver and gold and for clothing. THE LORD had made the Egyptians favorably disposed toward the people, and they gave them what they asked for" in Exodus 12:35-36. Thus, linguistic archeology via the approach of bilingual etymological match surprisingly verifies biblical records. The hero Moses was guest 賓 of Pharaoh and Midian, and 賓 guest has step to set out to go (gu). In Exodus 2:15, "Moses fled from Pharaoh and went to live in Midian". The other etymology of shore is Jonah, who stepped $\boldsymbol{\omega}$, theoretically by shoes, to the restricted palace of Nineveh $\rightarrow \vec{r}$ as a visitor vomited to shore, after a potential shipwreck on horrible sea i $i$. It has cargo as wealth as "they threw the cargo into the sea to lighten the ship". 畔 coast has saco (半 halves) and altar $\mathrm{T}$ (田). 灘 beach is to char bird 隹 and ox 革 on fire 入 after disaster 難 of Noah's flood 识。 革 also means leather 革. 
3.8.5 Crime 罪, Transgression 蕉, and Penalty 刑's Etymology

In Genesis 4:2-16, "Later she gave birth to his brother Abel. Now Abel kept flock, and Cain worked the soil. In the course of time Cain brought some of the fruits of the soil as an offering to THE LORD. But Abel brought fat portions from some of the firstborn of his flock. THE LORD looked with favor on Abel and his offering." "So Cain was very angry" and killed Abel accidentally. Besides accident as Cain cide and label as Abel (Du, 2020c), crime is micre, migrate, and criminal has Cain to immigrate. As this crime involved offering, 罪 crime has 四 altar with division 非. With the affix of liquid $*$, 䞏 crime has blood and walk 行, and is emicre, emigrate for transgression, as "Your brother's blood cries out to ME from the ground. Now you are under a curse and driven from the ground, which opened its mouth to receive your brother's blood from your hand." "You will be a restless wanderer on the earth." So, blame is abel m, Abel's blood. Letter m can represent liquid, for instance, serum and milk. The grim punishment was migration, although pilgrimage also has to migrate (migrage). Both the first and second earliest biblical crimes involve migration as grim punishment, as in Genesis 3 "GOD banished him from the Garden of Eden to work the ground from which he had been taken" and "drove the man out". Driven away, they could have grimace. 秽 grime, migre, has migration $¥$ related to crop 禾. 蕉 transgression has two trees $\psi \psi$, tree of intelligence and tree of life, the affix of relocation 追, 辛 hard labor, and man 子 for the original sin. If $\psi \psi$ is considered as a field, it is also the sin of Cain as son of Adam to kill Abel's life. Transgression is to go out (egrate) of a region. Culprit has culti of cultivate and culret of culture. Culprits trip and cultivate the ground. 罪行 crime has no 非 eye 目 but 行 migration, as they "must not eat fruit" of the tree "pleasing to the eye, and also desirable for gaining wisdom". Crime is micre, migrate out of Eden Garden. 非 also mimics tree. 目 can also be altar with division, as Cain should not have quarreled about offering.

Cain said to THE LORD that the punishment was more than he could bear, and "I will be a restless wanderer on the earth". LORD showed mercy, "if anyone kills Cain, he will suffer vengeance seven times over." "Then THE LORD put a mark on Cain" for him not to be killed too, as when anyone knew this warning sign from GOD to not to kill someone but still killed, it would justify the seven times. 報 revenge has shepherd Abel 太, sheep 羊, another person Cain $r$, and hand $₹$. It is not simply the killing, but deliberate killing to break the warning prohibition from GOD to deserve the seven times of vengeance. The label has Abel, as it has the absence (1) of Abel. 簽 label has divided offerings, restricted (一) altars 口口 and

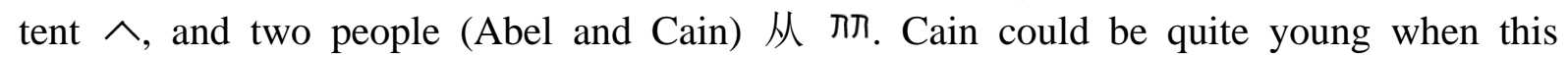
occurred before the birth of Adam's third son Seth, as his age of 50 could be like 15 years old of today, when GOD had not reset human lifespan.

征得, long march, has the affix of path 于, foot $\forall$ and altar or place 口, as GOD led Moses' people to march into the promised land. 惩 to punish, punitive and penalty have long march, as LORD said to Abraham, "I will punish the nation they serve as slaves, and afterward they will come out" in Genesis 15:13-16, and Adam and Eve marched out of Eden garden in penalty. 刑 形 penalty is to step from one land 土 to another land 土. 型 mode (move away) and type (step) are related in etymology. Punish is no (ni) position (pusi), or not ( $一$ ) to stay 
(止), and penal is not (na/nal) at the place. Other legal terms, such as jail, guilt, correction and police, have been presented ( $\mathrm{Du}, 2019 \mathrm{a}-\mathrm{c}$ and 2020a-e and this article).

\subsubsection{Pentecost's Sound and Tone}

"When the day of Pentecost came, they were all together in one place. Suddenly a sound like the blowing of a violent wind came from heaven and filled the whole house where they were sitting. They saw what seemed to be tongues of fire that separated and came to rest on each of them. All of them were filled with The Holy Spirit and began to speak in other tongues as The Spirit enabled them." "Crowd came together in bewilderment, because each one heard them speaking in his own language." Utterly amazed, they asked: "Are not all these men who are speaking Galileans? Then how is it that each of us hears them in his own native language? Parthians, Medes and Elamites; residents of Mesopotamia, Judea and Cappadocia, Pontus and Asia, Phrygia and Pamphylia, Egypt and the parts of Libya near Cyrene; visitors from Rome; Cretans and Arabs - we hear them declaring the wonders of GOD in our own tongues!"

Pentecost's sudden sound and tones enable loud sound to be native towns' sound [響 䇾解

$($ loud sound $)=$ 鄉 $($ native town $)+$ 音 (sound) $]$. Two lines $=$ are dou ble 1 of loud. 踶 two persons in worship represent gathering disciples. 語句, words and sentence, link to Pentecost 五旬, consonant with languages as a testimony for Holy Spirit's arrival.

\subsubsection{Elephant, Dolphin and Creation}

象里暴 elephant has the affixes of ear $3(\mathrm{Du}, 2019 \mathrm{c})$ and sound, phane [pho(a/e)no(e/i)] of Greek in phone, telephone, phonetic, phonics, phonology, phoneme, phenomenon, phonographic, phenotype, phenol, phantasy and phantasm. The structure of phenol @ was from a phantom of dream. Phenomenon has phen of elephant, and appearance has ear 3 . Elephant is elevated phone, because elephant's sound resembles loud and elevated blast of Exodus 17:15-24:4, as "with a thick cloud over the mountain, and a very loud trumpet blast", "LORD descended on it in fire" and "the sound of the trumpet grew louder and louder". "On the morning of the third day there was thunder and lightning, with a thick cloud over the mountain". "When the people saw the thunder and lightning and heard the trumpet and saw the mountain in smoke, they trembled with fear." "He got up early the next morning and built an altar at the foot of the mountain and set up twelve stone pillars representing twelve tribes of Israel". Thus, elephant and its legs resemble the mountain and pillars. When elephant walks, earth shakes, as Sinai Mountain was shaken.

Rabbi Jesus cured an arrester's cut ear and encouraged the courageous Peter to put off sword, and correspondingly ear ( 3 , 耳) is in hare 兔, arrest 缉, courage 敢, cure and encourage 勉. In English, French, Latin, Greek and additional languages, dolphin has phoni and phin as an affix of sound to send and sense ultrasound. Thus, after species were created, CREATOR apparently embedded scientific knowledge in predestined biblical etymology of created words of creatures such as dolphin and elephant. 
Because of appearance, in the language of China elephant means image, appearance, picture, portrait, vision, phenomenon, mirage, phantom, phantasm, appear to be, to look like, or look as if 像/象. Linguistic confusion at Babel tower (to check mankind and prevent self centrism. GOD even sacrificed The Only Son in Self Sacrifice for biblical altruism) makes truth harder to differentiate from error. Correspondingly in etymology, 偽 phony has phon as an affix, and error can be from appearance, as reaction and appearance are often misleading. For instance, people of Sodom misconsidered two transfigured angels as men. Church mispersecuted Galileo and Bruno, although Jesus demands disciples not to murder and judge. In Matthew 7:1-2 and Luke 6:37-42, "Do not judge, or you too will be judged." 為, purpose/aim/for, resembles elephant (as why purpose is similar to porpoise, and aim is in image), but was misinterpreted for almost two millenniums as human and monkey. It was only after excavation of the more ancient bone script language that linguists conclude that 蓉 represents elephant driven by human hand. However, this word has far more hint than a mere confusion between monkey and elephant - human is not from monkey no matter how to look as if. Human ancestors universally honored ancestors and commemorated spiritual afterlife, and bible solemnly claims that human beings were created in THE IMAGE OF GOD. If bible was interpreted correctly in the past millennium, there should not have been a fully false hypothesis of natural origin, because this hypothesis' order of species is the same as Moses' order of species recorded in bible. Both are from water to land, from plant to fish to bird to land moving creatures and then to human, and both claim mankind as the last species, when generally no myth humbled human as the last rather than the first. Moses was much earlier and did no need to dig fossils to present such an order of species, so that the Genesis writer Moses had to be true in logic. No insects give any newer insect, no fish gives any newer fish, no birds give any newer bird, no reptiles give any newer reptile, no mammals give any newer mammal, no plants give any newer plant, and no germs give rise to any newer germ, except being created in laboratories as synthetic life. Language and nature were created both to reveal truth and to perplex cognition, in order to unambiguously select real lovers for eternal life, for example, those truly faithful to GOD to defend biblical truth, rescue persecuted Jews and natives, and fight against massacres, so as to believe in heart in faith and action to obey law of love during colonization and holocaust. The affixes of encephalo and cephalo represent brain in Latin and Greek, as they have phone and/or face, giving rise to cephalic, macrocephalic, cephalopod, cephalalgy, cephalothorax, encephalitis, hydrocephalus, anencephalic and electroencephalogram.

\subsubsection{Appearance of Son and Angels}

Witnessed by three apostles, "He was transfigured before them. His Face shone like the sun, and His clothes became as white as the light.” 貌 貌 face or appearance was initially written as 皃, including Man/man ‘2 and white 白 as 日 sun light to be reminiscent of Son 兒. 采 多 could be 勿 叉, not to offer physical lamb, as Jesus has sacrificed once for all. 当 / $\ni$ (side view) can also represent sacrificed Lamb or clothing, as initial clothing was leather represented by livestock $\widehat{\star}$. So 貌 can be Son's white clothes. Containing such fluorescence, 藐 flout has thorns ${ }^{++}$of Son, as in John 19:2 "soldiers twisted together a crown of thorns and put it on His Head". 
貌 can also represent appearance of angels. In Ezekiel 1, “Their faces looked like this: Each of the four had the face of a human being, and on the right side each had the face of a lion, and on the left the face of an ox; each also had the face of an eagle. Such were their faces." "The appearance of the living creatures was like burning coals of fire or like torches". "I realized that they were cherubim. Each had four faces and four wings, and under their wings was what looked like the hands of a man. Their faces had the same appearance as those I had seen by the Kebar river.” Thus, 貌 貌 face/appearance has creature such as lion or horse

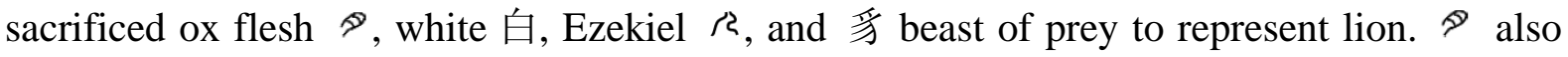
resembles an eye. "Their rims were high and awesome, and all four rims were full of eyes all around." "Each of the four living creatures had six wings and was covered with eyes all around" in Revelations 4:8. 藐 disdain has to condemn "the dragon and his angels" in 12:3-9 and 20:1-3, the beast from the Abyss in Revelations 11:7, the two beasts of Revelations 13, and the beasts in Revelations 17 and 19.

The appearance of angel is also reflected by additional words. 鬼戛 angel or ghost has 6 as cloud or fire to ignite (egna), worshiper $々$, and burnt altar with copper grating $⿴$, and apparition partitions offering. For instance, in Judges 13 Manoah said to an angel, "we would like you to stay until we prepare a young goat for you." Then Manoah took a young goat, together with the grain offering, and sacrificed it on a rock to THE LORD. "The woman gave birth to a boy and named him Samson”. This offered goat was related to ghost. 魂 soul has 云 cloud and 鬼 ghost (Du, 2020c), and 魄 spirit or soul has 当 fire, 6 cloud and ghost 鬼, as in 2 Peter 3:11-13 "That day will bring about the destruction of the heavens by fire, and the elements will melt in the heat. But in keeping with HIS PROMISE we are looking forward to a new heaven and a new earth, the home of righteousness."

魔 satan/demon has angel 鬼, the two Eden trees 木木, and the affix of building 广 (side view of tabernacle), as satan is not saint, tempted Eve, and had Jesus to stand on the highest point of temple in Mark 1:9-13, Matthew 4:1-11 and Luke 4:1-13. "If You are The Son of GOD," he said, "throw Yourself down. For it is written: "HE will command HIS angels concerning You, and they will lift You up in their hands, so that You will not strike Your Foot against a stone." "Eve did not overcome, but Jesus overcame temptation to refuse to jump from temple, as one etymology for tempt to have temple. The falling archangel and his followers render GOD to have to systematically test human beings who face temptations and confusions, in order to select truly faithful lovers for the eternal kingdom of peace. The fact that GOD executed violent people by great flood, gays in Sodom, and unbelievers in Exodus, and will again execute violators of law of love in final judgement is to ensure the eternal peace. GOD does not kill anyone now, and will not execute or punish anyone if they pass final judgement.

\subsubsection{Etymology of Son, Infant, Fiancé and Fiancée}

In multilingual match, 兒鼠 son has double legs, pedo/paedo/pedi of pediatrics, paediatrics, orthopaedics, paedophile, pedophilia and pedagogue. In Genesis 25:24, "his brother came out, with his hand grasping Esau's heel”. As $⿴$ 一 is container, worshiper near manger is also the etymology of Son 兒. 
Infant 嬰 has 女 woman full of the affix of wealth 貝 $\epsilon \ni M$, as Mary received costly treasures from Magi. $M$ also resembles $H$ pregnant woman with two legs and baby $\Downarrow$ in womb. In Matthew 2:1-11, Magi from the east came to Jerusalem and asked, "Where is The One Who has been born King of the Jews? We saw His star in the east". Herod called the Magi secretly, "Go and make a careful search for The Child". They went on their way until the star "stopped over the place where The Child was. When they saw the star, they were overjoyed." "Then they opened their treasures and presented Him with gifts of gold and of incense and of myrrh." 星 star has birthday 生日 because of Jesus Christ. 嬰 infant has finant of financial 財 due to the treasures such as gold from Magi, and the assumed ancient version 雨霓 was Magi 杂 carrying costly gifts 䨒鼠. Linguists interpreted this word as girl's decoration on hair braids, but how could an infant has such long queues? For the first time in human history, this testimony presents the etymology of infant 嬰 as financial gifts presented to Mary. Such words prove the accuracy of new testament. 櫻 cherry, human carry 需㪙, is thus not difficult to understand, as Magi carried all the treasure 寶 to visit Infant 嬰 of GOD. 櫻 cherry has Christ as Child 嬰 with the affix of wealth 貝. Cherry fruits look like treasure, and cherry flower looks like star, as a star guided Magi to carry the treasures to Son.

鸭 parrot has infant 婴, as it could talk like infant. Its etymology is also related to narration in parable. Parrot's greatest ability is to recite people's words. One of The Son's Greatest Ability was to recite THE WORD OF GOD. In John 7:16 Jesus answered, "My Teaching is not My Own. It comes from HIM WHO SENT Me." In Luke 2:46-52, 4:14-22, 10:21 and 12:11-12, "Everyone who heard Him was amazed at His Understanding and His Answers." In Matthew 13:34, "Jesus spoke all these things to the crowd in parables; He did not say anything to them without using a parable". "All spoke well of Him and were amazed at The Gracious Words that came from His Lips." "I praise YOU, FATHER, LORD of heaven and earth, because YOU have hidden these things from the wise and learned, and revealed them to little children." "Holy Spirit will teach you at that time what you should say".

缨 ribbon is born as infant 婴, as the cord of Judah led to 女 woman's twin babies, including Perez, the ancestor of Joseph who adopted Infant. In Genesis 38:14-30 "he gave them to her and slept with her, and she became pregnant by him." "See if you recognize whose seal and cord and staff these are." Judah recognized them and said, "She is more righteous then I, since I wouldn't give her to my son Shelah." "When the time came for her to give birth, there were twin boys in her womb." 绶 ribbon has two hands 孚 to hand over cord 受 near entrance $\cap$.

Fiancé (Joseph) and fiancée (Mary) are related to finance and infant due to Infant and the received financial treasures. In Matthew 1:20-2:11 an angel of THE LORD appeared to him in a dream and said, "Joseph son of David, do not be afraid to take Mary home as your wife, because What is conceived in her is from The Holy Spirit".

\subsubsection{The Affix of Wealth 貝}

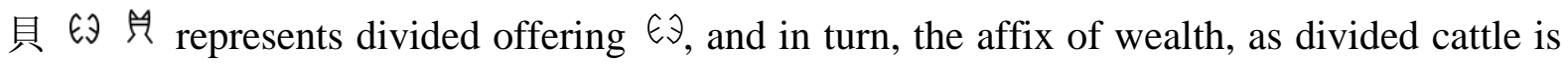
wealth, and fiscal is fission of calf in etymology. It also resembles pregnant woman, and children are inheritance. 資 capital is $Y$ split cattle, and related to capitalize, as priests kill 
cattle near altar. 賀 celebration and congratulation add 加貝 wealth or infant. In Luke 1:26-48, Gabriel congratulated Mary for the foretold Son. Both celebration and congratulation have altar, as wealth is divided for altar, and purification offering after pregnancy involves altar. Washed leather from burnt offering is also wealth, after skinning offering in Leviticus 1:6-7:8. 貝 is the root of wealth in words such as wealth 財, treasure 寶, trade 貿, merchandise 貨, capital 資, buy 買, sell 賣, purchase 購, and storage 貯.

Jesus was rich due to enriched Spirit and the financial from Magi, reflected by the term Christ. In Luke 4:1, "Jesus, full of The Holy Spirit, returned from the Jordan and was led by The Spirit in the desert". Christ is rich in charity, with The Anointed as etymology. In related etymology, orchid smells like perfume and symbolizes righteous character in culture. 富 rich is related to rheo, to flow, for anointing oil to flow. Christ is heroic. 富 圆 fortune has perfume urn 曷 for Tent of Meeting $\Pi$, and funeral and fortune have perfume (erfune). Although Jesus was rich and did not seek personal donation to Himself, He definitively declares in Matthew 5:9-6:24 "Blessed are the poor" and "Blessed are those who are persecuted because of righteousness, for theirs is the kingdom of heaven". Thus, 逼 to persecute is related to asset as fortune 富 and blessing as fortune 福. The additional etymology of blessing 祝 is else sibling 兄, as Isaac blessed Jacob instead of Jacob's twin brother. To persecute is related to security, and secure (secnre with $u$ n rotation) is censer for incense, as The Anointed Christ was persecuted. To anoint and anointment are related to cinnamon. In Exodus 30:22-38, "Take the following fine spices: 500 shekels of liquid myrrh, half as much (that is, 250 shekels) of fragrant cinnamon, 250 shekels of fragrant calamus, 500 shekels of cassia - all according to the sanctuary shekel—and a hin of olive oil. Make these into sacred anointing oil, a fragrant blend, the work of a perfumer. It will be the sacred anointing oil. Then use it to anoint the tent of meeting, the ark of the covenant law, the table and all its articles, the lampstand and its accessories, the altar of incense, the altar of burnt offering and all its utensils, and the basin with its stand. You shall consecrate them so they will be most holy, and whatever touches them will be holy. "Anoint Aaron and his sons and consecrate them so they may serve ME as priests"”. Thus, 副, a set of, is the whole set of fine spices as asset. 副 also means assistant priests as Aaron's sons. To assist is related to asset, and essential is incense to make sense. 幅 extent is size of a curtain of Tent of Meeting, as the whole tent must be anointed. 輻 spoke (skope/scope) of vehicle is the extension of a wheel.

The second etymology of 畐 is atonement cover (一), ark 口 and burnt altar 田. For instance, 輻 spoke of cart is for carrying ark and altar, and 逼 persecution is from 1 Kings 18 when "Jezebel was killing the prophets". The third etymology of 畐 is one (一) region (口) of field (田), and is in persecution 逼 because of the field of blood in Matthew 27.

Jesus demands that we "cannot serve both GOD and money". "No one can serve two masters. Either you will hate the one and love the other, or you will be devoted to the one and despise the other. You cannot serve both GOD and money", although Jesus was not talking about earthly "masters", because we must serve and love each other. He talks about THE MASTER. Accordingly, money is similar to venom, and 敵 enemy is similar to money of economy 商, as divine economy is to share wealth 八, an etymology from burnt offering related to thermal entropy 熵. In Acts 2:44-45, “All the believers were together and had everything in common. 
They sold property and possessions to give to anyone who had need." This is the highest economic ideology. Christianity is consistent with universal free medicare.

In Genesis 15:2, Abraham told GOD, "I remain childless and the one who will inherit my estate is Eliezer of Damascus". Abraham was rich but could inherit his wealth to a servant at the time of worldwide slavery, after he distributed wealth to nephew Lot, while in Luke 16:20-27 Lazarus was a poor beggar with sores, but a rich man did not help and missed eternal life. So it is the attitude and action of the rich to the poor that matter. 錢 money has two affixes of weapon $\mathbb{t}$, predestining that it is a huge temptation to sell weapons for money.

負貧 to carry has Israelite or Magi 》 with treasure 貝, as Egyptians gave Israelites silver and gold in Exodus 12:35-36, and in Matthew 2:11-12 "they opened their treasures and presented Him with gifts of gold, frankincense and myrrh. And having been warned in a dream not to go back to Herod, they returned to their country by another route" in disloyalty to earthly king in order to be loyal to GOD. Thus, 負 also means negative route and disloyalty, which puzzled linguists for thousands of years until now. Negative is not (ne) to go (ga) to, and disloyal is not royal.

\subsubsection{Music Instrument}

Israelites play music of amusement in front of Tent of Meeting to celebrate festivals. In Psalms 68:24-26, "In front are the singers, after them the musicians; with them are the maidens playing tambourines. Praise GOD in the great congregation; praise THE LORD in the assembly of Israel." 虞 amuse has music and the affix of piety 虎. In 1 Chronicles 16:40-42 and 25:1-8, "Heman and Jeduthun were responsible for the sounding of the trumpets and cymbals and for the playing of the other instruments for sacred song." "All these men were under the supervision of their fathers for the music of the temple of THE LORD, with cymbals, lyres and harps, for the ministry at the house of GOD." In 2 Chronicles 7:5-7, "The priests took their positions, as did the Levites with THE LORD's musical instruments". "Solomon consecrated the middle part of the courtyard in front of the temple of THE LORD, and there he offered burnt offerings and the fat of the fellowship offerings". Concert is to co cut. With $\Leftrightarrow$ fire from burnt altar, 樂 music has cis and simu/sumi in symmetry, as offering is cut in halves (semi means halves) (Moses, 2nd millennium B.C.a.). 樂 also means smile with semi, and 笑 laugh has half of the halves $\uparrow \uparrow$ to go (gu) $大$, as the selected half who are lovers will live forever in heaven to smile and laugh. As a common feature of words, music and smile exhibit bilingual match to biblical etymology.

韵/韻 melody has divided ( $\mathrm{d}+$ vowel means double) meal $\Leftrightarrow$. Orchestra has chest of ark and people, as in 2 Samuel 6:4-5 with the ark, David and the whole house of Israel were celebrating with songs and with harps, lyres, tambourines, sistrums and cymbals. In 2 Chronicles 29:26-28, "Levites stood ready with David's instruments, and the priests with their trumpets". "As the offering began, singing to THE LORD began also, accompanied by trumpets and the instruments of David king of Israel. The whole assembly bowed in worship, while the singers sang and the trumpeters played". Song is to sing in sin offering. Trumpet has drum, and instrument has trumet of trumpet 號 with the affix of piety 䖈. 


\section{$\triangle$ Macrothink}

Clarion and clarinet have cloud $\zeta(\mathrm{cl})$, as in Exodus 19:16-19 "with a thick cloud over the mountain, and a very loud trumpet blast", "the sound of the trumpet grew louder and louder". Clarinet has altar as in 2 Chronicles 7:1-7 and 29:25-28 "Levites stood ready with David's instruments, and the priests with their trumpets. Hezekiah gave the order to sacrifice the burnt offering on the altar. As the offering began, singing to THE LORD began also, accompanied by trumpets and the instruments", "while the singers sang and the trumpeters played. All this continued until the sacrifice of the burnt offering was completed". Clarinet involves cloud as "THE GLORY OF THE LORD filled the temple" when King Solomon and priests performed burnt offering. 笔 $\frac{+x}{5}$ flute has rising cloud.

肃肅肃 serious has pieces 片 in pair 片, as worshiper has to seriously sever serving to series of pieces. 箫 flute has to be played seriously, as in Psalms 150:4 "praise HIM with the strings and flute”. 繡 embroidery has to weave a pair of divine birds cherubim into curtain, as "They made the curtain of blue, purple and scarlet yarn and finely twisted linen, with cherubim worked into it”. 管督 pipe and tube have two steps, pi/pe, \& from place to place around tabernacle $\pitchfork$. 筝掙, horizontal harp, has 21-25 strings $\ulcorner$ played by both hands $\stackrel{m}{\exists}$ with divided offering $ヤ$. 笛 flute has burnt altar 田, 笙 reed pipe has ox 牛 $\Psi$, and 簧 reed has burnt altar 田 and ox 廿. 琴 harp has two kings, Saul and David, and is to harass, as in 1 Samuel 16:14-23 "David would take his harp and play. Then relief would come to Saul; he would feel better".

\section{Discussion}

Multilingual mutual match in biblical etymology is a major mystery of languages, as the definitive evidence for divine creation ( $\mathrm{Du}, 2019 \mathrm{a}-\mathrm{c}$ and 2020a-f). Because language is a hallmark of civilization, this major secret of civilization has been revealed since last year, through extensive bilingual and trilingual mutual match in biblical etymology that spans the entire dictionaries. Because the languages of China, English and Latin were created before biblical writing or introduction of christianity, these languages must have been divinely created ahead of time to predestinedly match bible and equally astonishingly, one another. For instance, the mutual etymological match between the languages of China and English is astonishingly extensive beyond nature.

Because ancient Japan, Korea and Viet Nam officially used the language of China for a long time, and currently have the languages extensively derived in semantic or phonic conversion from the language of China, these languages must originally have biblical etymology. For instance, the most popular word of Japan in 2019, 令, has worshiper $\mathbb{D}$ in front of The Graceful Holy Tent of Meeting $\triangle$. Because Latin, Greek, Italian, Spanish, German, French and additional languages either have common origin or shuttle words with English, these languages must match biblical etymology too (Du, 2019a-c and 2020a-f). Because of Spanish and the closely related language of Portugal, the entire Latin American languages must match biblical etymology. All the continents of our world are using languages that directly or indirectly match biblical etymology. 
The extensive bilingual mutual match in biblical etymology spans entire dictionaries. For example, all the analyzed words related to health, diseases, organs, body parts, numbers, days, calendars, colors, shapes, climates, seasons, directions, and relatives have biblical etymology

(Du, 2019a-c and 2020a-f). For instance in the category of shape, 狀 shape has one side of sheep $\hbar$ as priest's share, 塊 piece has ghost 鬼 and altar田, 球 globe has gold and the affix of robe 肯, and sphere has to dress ephod with pomegranates. In the category of textile, textile is exile, the affix of textile 条 is tricolor yarn, fabric has fried fire, and filament has flame from burnt altar. The etymology of heir, heritage and inheritance is to tear, and to inherit 繼 条造 break has to tear, fragment is to tear garment, to desperate is to tear apart dress, and 裚 blasphemy is to take 执 the split clothes 衣, when soldiers divided Jesus' garment to gamble for Lamb to go.

Among the many words firmly matching Jesus, the etymologies of mock 嘲, sarcasm 讽 and satire 譏 and their mutual translations all match events of Jesus. 嘲 mock is to temple 廟, to block (一) light (I) of sun $\ominus$ to come out, and to come from cross 十, as "darkness came over the whole land until three in the afternoon, for the sun stopped shining." "You Who are going to destroy the temple and build it in three days, save Yourself! Come down from the cross, if You are The Son of GOD!” 讽 sarcasm is to come from cross (crass) or crazy (cras) 疯, as Pharisees said, "He is possessed by Beelzebub! By the prince of demons He is driving out demons." Satire has Jesus' attire gambled by soldiers.

As obvious evidence for divine creation, there are multiple etymologies for so many words. For instance, starvation is related to harvest, taurus, several mine name, and hunter's hunger (Du, 2020c). Words are also interlinked in biblical etymology. For instance, 葡 grape vine prostrates 匍 in vineyard 固. In the sentence “The arrested Jesus cured a cut ear and encouraged the courageous Peter to put off sword”, ear ( 3 色, 耳) is in arrest 缉, cure, courage 敢, and encourage 勉. In the sentence "Mute Zechariah's son John heard SOUND to Son from cloud before his arrest in prison and His empty tomb in town", 音离 SOUND is

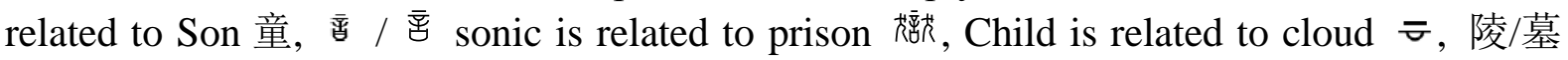
tomb is motion in mobility (官) without (莫) Son of Man (士), mute is inhibited motion of sound, and town is motion as own tone.

In addition to the definitive linguistic evidence for creation and extensive biological logic, there is powerful evidence from all the created species, because creatures were created to symbolize biblical events, and words of creatures are embedded with biblical etymology ( $\mathrm{Du}$, 2019b/c and 2020a-e). For example, gigantic dinosaurs were created to symbolize biblical dragon, elephants are created to remind Sinai mountain, pillars and phonic trumpet, and the nut of great tree oak resembles Abraham's tent. In multiple languages, dolphin has phin as phonic affix because it sends ultrasound. 我 goose has ego 我 and osteo growth to remind “bone of my bones”. 螳螂 mantis resembles 郎 man at hall 堂 to pray, 曼 tendril resembles spreading lines of blood sprinkled on curtain, 藤 vine has vessel 舟 $\mathrm{A}$, 小 fire, 绉 two hands and Noah's vineyard $\psi \psi$, 瓣 clove is created to resemble cloud $\bar{\sigma}$, 莒 sepal has 
rising cloud $\overline{5}$, and 冠闵 corolla has crown $\cap$ and man $s$ taken $\neg$ to cloud $=$. Thus, both plants and animals match biblical etymology.

In addition to the revealed biblical origin and etymology of heavenly stem and earthly branch calendar systems (Du, 2019c and 2020d), this article presents biblical interpretation for the seven days of a week in human culture and calendar. Although Monday was considered as moon day, Thursday as Thor day, and Sunday as sun day in the past, this article also considers Monday as mono day and no emission day, Tuesday as two water day, Wednesday as water condensation and new seed day, Thursday as thermal star day, Friday as fruitful fifth Day of fish and feather, Saturday as taurus day, and Sunday as seven day. 忿 anger has avenge. 分 segregation has anger and rage. 惱 wrath is thermo fire 《 to thaw and warn, fully consistent with the end of biblical time, although 《I can also be flood water. 稗 weed was considered as 卑 inferior wheat 禾, although its biblical etymology is related to Jesus' parable of divine selection when sunlight $P$ will be blocked $(-)$ and star $\theta$ will fall from sky ?, indicating divine confusion of human languages until the historically set time.

This article presents quite a number of affixes, such as 乍 restricted motion, 巨 curved migration, 天 human to flee, 兆 water or fire, 曼 curtain, 夋 as a motion affix, 用用, 甫 宙 and 角苗 as altar's service, and 急 co-carriage of ark or altar. 殳 of 款 grain means killing due to Cain's grain offering. 匽, to flee and hide, is for Moses' mother and sister to hide him in a basket $\odot$ near Nile bank 堰, or for Hagar to run away to water source. Numerous words with these affixes are presented. For example, derived from blocked motion 乍 of dynamite powder, 炸 to blow is not (一) mobile, and blast is not to pass. 稠 dense is 禾 seeds on altar 周. This linguistic analysis solves the semantic origin of numerous words.

In definitive etymology, 恐 唔 terror is error for people ? to mistakenly take ark with two poles 工 to battlefield. 謬 韵 error has people $\supset$ and two cherubim 坊 of ark to carry, when 人 people's blood $三$ was shed. 翊 mistake is to mistakenly take the ark marked by cherubim $\geqslant$ 坊 it, indicating the definitive requirement to respect GOD.

恐珒 terror also has worshiper ₹ with braids $\neq$ to work 工 in prison, and is related to arrest, torture and interrogation. 俘 arrest has hand $\pi$ to arrest son (子) of man (人). 逮 arrest has hand $\supsetneq$ to reach braids $\uparrow$, and is man at rest, as Samson was arrested after rest. Torture is to this biblical judge of great force, and reflects human terrors. The divinely called Samson fought against such terrorism by taking away his own life as arranged by GOD. This and recent articles present high etymological matching frequency per biblical page for Samson, Elijah and Jonah (Du, 2019c and 2020c/e and this article), indicating the apparent existence of these three historical prophets. For instance, among the double digit words matching Jonah, 辨 to distinguish left and right is related to Jonah's debate 辯, and to forgive 諒 is related to whale 鲸 and capital city 京, although taboo label 黝's capital city is of Cain and Abel. The biblical book of Jonah is surprisingly validated by etymological analysis through bilingual biblical match.

In theology, family has flame for kin to kindle. Oath is to heat offering and cut offering with hatchet. Pledge has the ledge of burnt altar near where priests peel off leather. To swear is to 
wear in consecrating priests. The biblical oath is to love GOD with all our soul, all our strength and all our heart!

\section{Conclusion}

Multilingual mutual match in biblical etymology is a secret of civilization and definitive evidence for creation revealed in this article. Through extensive bilingual mutual match in biblical etymology that spans the entire dictionaries, this major secret of civilization is firmed revealed. In conclusion, the entire languages of English and China and also words in additional languages must have been divinely created in etymology to predestinedly match bible and equally astonishingly, each other, as the origin of language.

Many biblical books such as Genesis, Exodus, Leviticus and Jonah are validated by multilingual mutual match in biblical etymology, a surprising approach presented for the first time in history. The systematic bilingual match in biblical etymology spans all categories, although languages have been divinely confused to hide this main secret of civilization, multilingual mutual match in biblical etymology, until now. The biblical etymology of many words and affixes are presented, and creatures were embedded with biblical etymology and created to symbolize biblical events.

In this couple of years, systematic testimonies indicate that ancient languages have bible as their definitive etymology, with multilingual mutual match in biblical etymology (Du, 2019a-c and 2020a-e). The complete validation of divine creation of words is a conclusion statistically definitive by both random sampling of words in several languages and concentrated etymological analysis of specific categories. From Genesis to flood, from numbers to heavenly stem and earthly branch calendars, from Eden garden to crossing Red sea, from Abraham's cut to two to Jesus' baptism, from Moses' miracles to Leviticus' decrees, from prophet and priest to tabernacle and altar, from health to diseases, from organs and body parts to all relatives, words extensively and systematically match biblical etymology with bilingual mutual match throughout dictionary, definitively proving that words in the languages of English and China were divinely created to mutually match each other in biblical etymology. Because the language of China was created before biblical writing, and English and Latin were present before the introduction of Christianity, these languages must have been divinely created ahead of time to predestinedly match bible and equally astonishingly, each other! Because the ancient languages of Japan, Korea and Viet Nam are extensively derived from the language of China, these languages must originally have biblical etymology. Because many languages have common origin or shuttle words with English and Latin, these languages must match biblical etymology too.

Jesus, Son of GOD, is validated linguistically beyond statistical coincidence. This is an important discovery in linguistic archaeology and theology and surprising approach to validating scripture. Linguistic archeology by the approach of bilingual etymological match surprisingly verifies biblical records. This greatly encourages faithful lovers to love GOD with all the soul, all the strength and all the heart, and accordingly, love each other too. 


\section{Macrothink}

International Journal of Linguistics

ISSN 1948-5425

2020, Vol. 12, No. 5

\section{Acknowledgement}

We are grateful to GOD THE LORD, THE CREATOR of heavens and earth, with full gratitude in the highest respect.

\section{References}

Du, James X. (2019a). Bilingual dissection of words with biblical correlation. International Journal of Language and Linguistics, 7(1), 50-54. https://doi.org/10.11648/j.ij11.20190701.17

Du, James X. (2019b). Bilingual match to biblical flood. International Journal of Linguistics, 11(1), 196-216. https://doi.org/10.5296/ijl.v11i1.14434

$\mathrm{Du}$, James X. (2019c). Seven days, numbers and heavenly Stems. International Journal of Linguistics, 11(2), 107-151. https://doi.org/10.5296/ijl.v11i2.14755

$\mathrm{Du}$, James X. (2020a). Biblical etymology of prophet and priest. English Literature and Language Review, 6(4), 54-63. https://doi.org/10.32861/ellr.64.54.63

Du, James X. (2020b). Biblical etymology of tabernacle and altar. International Journal of Linguistics, 12(3), 9-27. https://doi.org/10.5296/ijl.v12i3.17012

Du, James X. (2020c). Biblical etymology of organs and body parts. English Literature and Language Review, 6(5), 69-90. https://doi.org/10.32861/ellr.65.69.91

Du, James X. (2020d). Biblical etymology of earthly branches and Jesus Christ. SocArXiv. https://doi.org/10.31235/osf.io/r9mdz

Du, James X. (2020e). Biblical etymology of relatives. SocArXiv. https://doi.org/10.31235/osf.io/dus45

Du, James X. (2020f). Jesus Is Son of GOD. LawArXiv. https://doi.org/10.31228/osf.io/48nyx

$\mathrm{Du}$, James X. (2020g). Jesus Christ demands good deeds--Faith and action is required for eternal life. SocArXiv. https://doi.org/10.31235/osf.io/ba4cg

Ge, H. (n.d.). 4th century. Prescriptions for Emergent Reference (Alternative name: The Handbook of Prescriptions for Emergencies). Retrieved from https://en.wikipedia.org/wiki/B

Isaiah. 1st millennium B.C. Isaiah.

James. 1st century. James.

John. 1st century a. John.

John. 1 st century b. Revelations.

Joshua. 2nd millennium B.C. Joshua.

Luke. 1st century. Luke.

Mark. 1st century. Mark.

Matthew. 1st century. Matthew.

Moses. 2nd millennium B.C.a. Genesis. 


\section{Macrothink}

Moses. 2nd millennium B.C.b. Exodus.

Moses. 2nd millennium B.C.c. Leviticus.

Moses. 2nd millennium B.C.d. Numbers.

Moses. 2nd millennium B.C.e. Deuteronomy.

Paul. 1st century a. Hebrews.

Paul. 1st century b. Romans.

Paul. 1 st century c. 1 Thessalonians.

Samuel. 1st millennium B.C.a. 1 Samuel.

Samuel. 1st millennium B.C.b. 2 Samuel.

Sima, Qian. 1st century B.C. Records of the historian.

Standing For Truth. (2020). Why Human Evolution Is False: The Scientific Case For Independent Origins: Has Ape-to-Human Evolution Been Overturned?. Independent Publisher.

Unknown author. 1st millennium B.C.a. 2 Chronicles.

Unknown author. 1st millennium B.C.b. 1 Kings.

Unknown author. 1st millennium B.C.c. 2 Kings.

Unknown author. 1st millennium B.C.d. Psalms.

Unknown author. 1st millennium B.C.e. Judges.

Unknown author. 1st or 2nd millennium B.C. Job.

Unknown author. 1st century. Acts.

Shen, X. (100-121 A.D.). Analytical Dictionary of Characters.

Zuo, Q. M. (n.d.). First half millennium B.C. Left Legend.

\section{Copyrights}

Copyright for this article is retained by the author(s), with first publication rights granted to the journal.

This is an open-access article distributed under the terms and conditions of the Creative Commons Attribution license (http://creativecommons.org/licenses/by/4.0/) 